\title{
A FRESH LOOK AT HUNNIC CAULDRONS IN THE LIGHT OF A NEW FIND FROM HUNGARY ${ }^{1}$
}

\author{
ZSÓFIA MASEK
}

\author{
Hungarian Academy of Sciences \\ Research Centre for the Humanities, Institute of Archaeology \\ Tóth Kálmán utca 4, H-1097 Budapest, Hungary \\ masek.zsofia@btk.mta.hu
}

To Péter Tomka, with gratitude

\begin{abstract}
The discovery of a fragment of a Hunnic cauldron by a metal detectorist acted as the springboard of this study, in which various aspects of Hunnic cauldrons are discussed: their findspots and find contexts, their typology, their dating and their origins. Questions regarding the broader cultural context of Hunnic cauldrons in the Roman and the Hunnic Empires are also addressed, as are their functional, ritual and social dimensions. The archaeological findings are complemented by metallographic analyses that shed light not only on the composition of the cauldron, but also on its possible use.

Keywords: Hunnic cauldrons, typology, rite, Carpathian Basin, Hun-period cultural complex of the Middle Danube region, Eurasian cultural contacts
\end{abstract}

\section{THE ÓCSA CAULDRON}

The fragment of a Hunnic cauldron, the second of its kind from the Hungarian Plain, came to light in December 2014 on the outskirts of Ócsa (County Pest), exactly 145 years after the discovery of the renowned Törtel cauldron. The fragment was found by an amateur metal detectorist, who realised he had stumbled upon a Hunnic cauldron and presented it to the Ferenczy Museum, the regionally authoritative institution. ${ }^{2}$ It was clear from the findspot's coordinates that the location was not a registered archaeological site and therefore we surveyed the area on March 27, 2015, ${ }^{3}$ in the course of which we collected prehistoric, Roman-period Sarmatian and medieval pottery sherds. The multi-period site was registered as Ócsa-Felsőbabád, Kincses-hegy. The low hill known as Kincses-hegy [Treasure Hill] lies south of the cauldron's findspot - as so often, the origin of its name remains shrouded in obscurity.

We found relatively few Sarmatian-period pottery sherds during the field survey. The collected pieces included a few a late Sarmatian-period pieces (the so-called late Sarmatian-period gritty ware and the body fragment of a grey, untempered, small biconical vessel). ${ }^{4}$ Knowing that the finds of the late Sarmatian and the Hun period (in the narrow sense) overlapped slightly on the Hungarian Plain, ${ }^{5}$ it could be plausibly argued that the cauldron fragment can be associated with the late Sarmatian-period settlement, although this cannot be proven on the basis of the field survey data. The small size of the Sarmatian settlement compared to the period's other sites on the Hungarian

\footnotetext{
${ }^{1}$ This study was written within the framework of research project NKFI/OTKA NK 111-853.

${ }^{2}$ The cauldron fragment was discovered by József Fojta, a resident of Dabas. I am grateful to Gábor Lassányi for informing me about this find. Tibor Ákos Rácz of the Ferenczy Museum in Szentendre participated in the registration of the find and in the subsequent investigation of the site. I am indebted to them all for their generous help.

${ }^{3}$ The participants of the field survey were Ákos Tibor Rácz, Anikó Bózsa and Róbert Patay (Ferenczy Museum), Rozália DOI: 10.1556/072.2017.68.1.4
}

Bajkai, Katalin Gergely, Anett Miháczi-Pálfi and the present author (Institute of Archaeology, Research Centre for the Humanities, Hungarian Academy of Sciences), and József Fojta. I would here like to thank them for their help.

${ }^{4}$ The cauldron was inventoried under inv. no. 2016.4.1.1; the selected material of the field survey was inventoried under inv. no. 2016.4.1.2-73. 2014.

${ }^{5}$ КУЛЬЧАР-ИштвАНОВИЧ 2013; IsTVÁNOVITS-KuLCSÁR

Acta Archaeologica Academiae Scientiarum Hungaricae 68 (2017) 75-136 0001-5210/\$20.00 (C) 2017 Akadémiai Kiadó, Budapest 


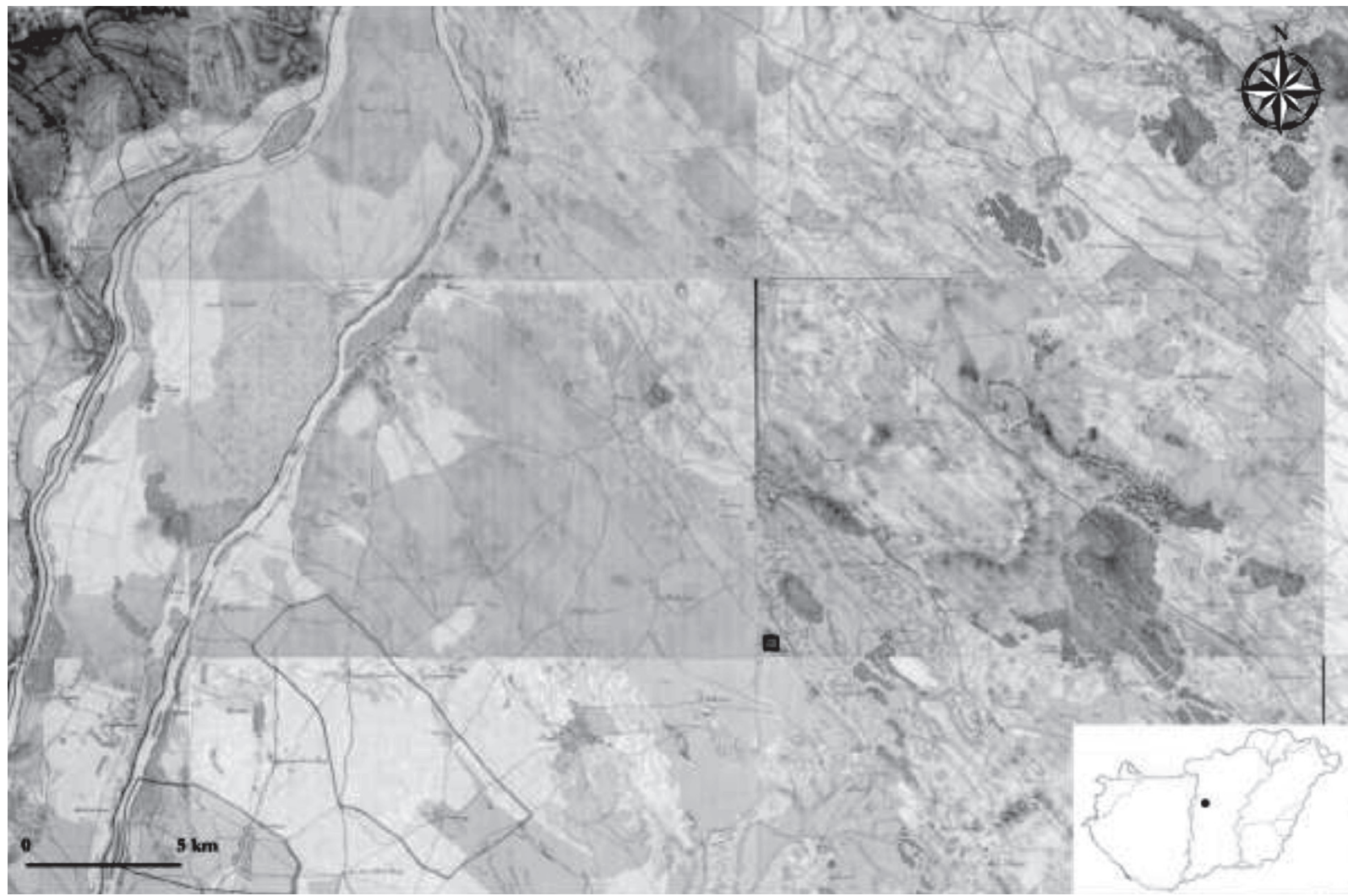

Fig. 1. The natural environment of the findspot of the Ócsa cauldron fragment on the map of the First Military Ordnance Survey (graphic: Zsófia Masek)

Plain and its non-intensive occupation suggest that it cannot have been a major centre. A subsequent metal detecting survey did not yield any metal finds from the proximate centuries (such as Roman coins).

The fracture surfaces of the fragment are old, suggesting that the fragment had become buried in a broken condition. It must here be noted that the cauldron fragment lay a few metres from the base of the transformer of a high-voltage aerial cable. We know nothing about when the latter was established, but it seems quite certain that its construction was not monitored archaeologically and thus we cannot exclude the possibility that the cauldron fragment had not lain in the ploughed humus originally, but much deeper, and that it had been turned out when the concrete base was made. In this case, the archaeological context was destroyed during the twentieth century, which in turn suggests that additional fragments from the cauldron could still lie undetected at the site. We did not conduct a control excavation on the site in view of the transformer's location and because the site appears to have been intensely occupied between the Árpádian Age and the late Middle Ages.

The site lies in the Csepel Plain micro-region. The region extends along the boundary between the sand ridges of the Danube-Tisza interfluve and the reed beds in the former channel of the palaeo-Danube. The area between the sand region and the Danube Valley is a deep-lying area extensively covered with water and is therefore characterised by large fens and swamp forests, and mosaic associations (meadows, woods, sedge marshes and steppe meadows). ${ }^{6}$ An ancient road runs along the boundary of the bog basins, which started from the Danubian fording place in the Buda and Pest area, running south-eastward to the Tisza region and the Maros mouth (roughly along the line of Road 5, Budapest-Kecskemét-Szeged). The site lies immediately beside this road, whose forerunner appears of the map of the First Military Ordnance Survey (Fig. 1).

Judging from the uneven fracture surface above the upper rib, the cauldron fragment comes from the shoulder part since a fracture of this type would be unfeasible in the case of a rim fragment. The entire surface of

${ }^{6}$ DÖVÉNYI 2010, 34-39. 

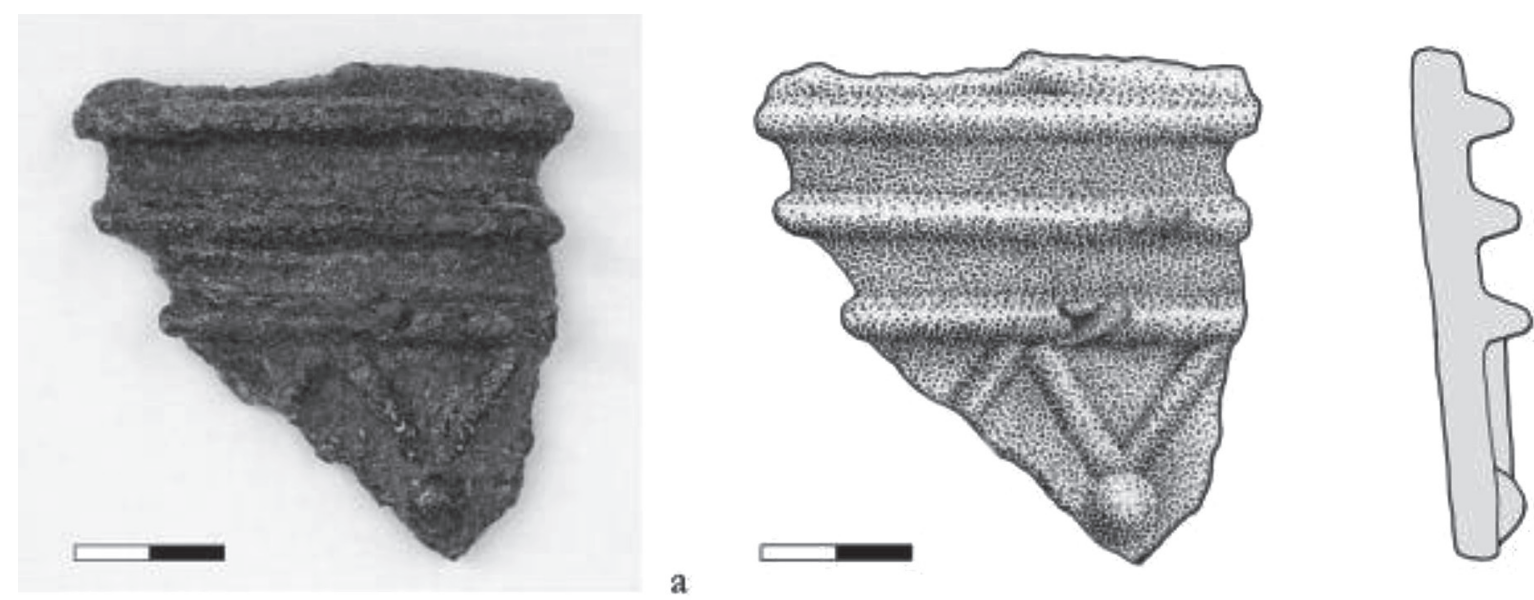

a

Fig. 2a-b. The cauldron fragment from Ócsa (photo: Péter Hámori, drawing: Péter Posztobányi)

the shoulder fragment is decorated. There are three transverse ribs of the same thickness $(0.4-0.7 \mathrm{~cm})$ on the upper part, under which runs a row of triangular motifs created from smaller ribs with an identical section. The inverted triangles terminate in a raised semi-spherical motif. The fragment bears one triangular motif and a small section of an oblique rib. All three transverse ribs are damaged, most likely caused by an agricultural machine. The inner side, especially the upper section, is strongly corroded. The fragment has a height of $6.6 \mathrm{~cm}$, a width of $6.4 \mathrm{~cm}$, a wall thickness of $0.6 \mathrm{~cm}$ and a max. thickness of $1.2 \mathrm{~cm}$ (with the ribs). The triangular motif has a length of $2.7 \mathrm{~cm}$, the semi-spherical motif a diameter of $1 \mathrm{~cm}$. The fragment weighs $143 \mathrm{~g}$ (Figs 2-3).

The cauldron fragment from Ócsa raises several issues, which have since long been debated in the research on cauldrons. In view of the triangular ornamental motif, a discussion of a few typological issues seems in order, while the fragmentary nature of the find, the findspot that can perhaps be associated with a barbarian settlement lying on the fringes of a bog on the Hungarian Plain calls for a general overview of the find contexts of similar cauldrons. Several new pieces, principally from Russia, have been published since the last comprehensive studies on cauldrons, which raise a spate of new questions and a need to re-visit old ones. An overview of the academic literature led to a general survey of the most important issues in the study of caul-

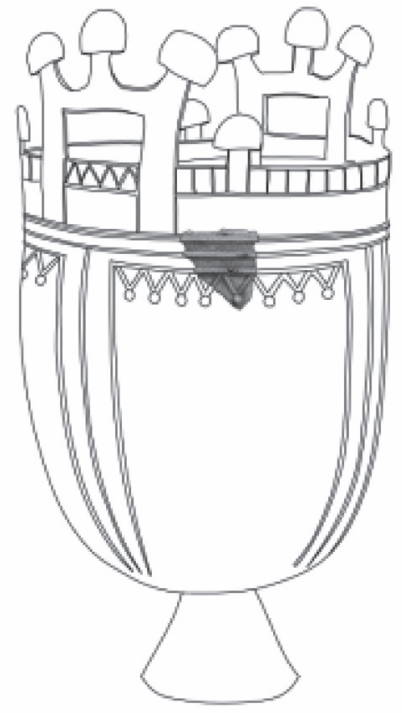

Fig. 3. One possible reconstruction of the cauldron fragment from Ócsa (graphic: Zsófia Masek) drons since several points can be viewed in a new light if we take the original publications as our starting point and take a fresh look at this research theme, dusting off earlier presumptions and removing the century-old research concepts whose archaeological foundations can often be reasonably challenged.

\section{THE FINDSPOTS OF NEW HUNNIC CAULDRONS}

Several new Hunnic cauldrons have been discovered since the publication of the most recent comprehensive studies, complete with catalogues, around the turn of the millennium. ${ }^{7}$ A mushroom-shaped handle was found in Moravia in 2009 during metal detectoring (Fig. 4), ${ }^{8}$ and the Ócsa fragment published here was similarly found by a metal detectorist in 2014. One remarkable cauldron was found at Balatonlelle-Rádpuszta in 2006, during the

${ }^{7}$ ÉRDY 1995; КосH 1997; ANKe 1998, 48-55.

${ }^{8}$ BŘíZA-JANÁKOVÁ 2010. 


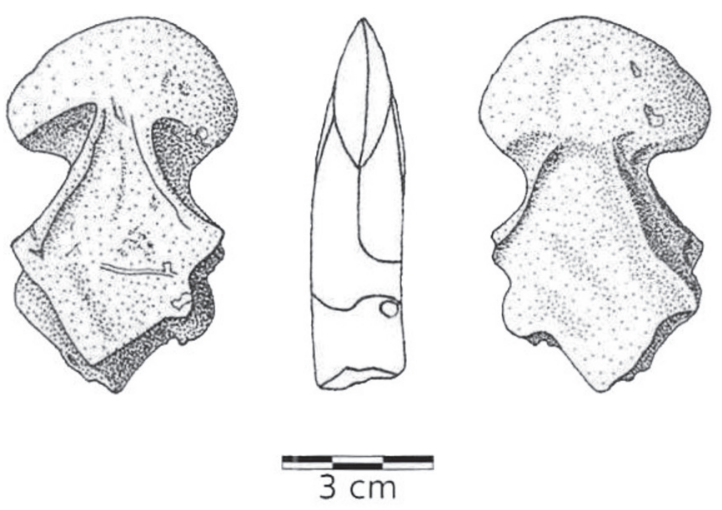

Fig. 4. The Lichnov cauldron fragment (after BŘíZA-JANÁKOVÁ 2010)

pre-development excavation of a major construction project. The cauldron lay tilted on its side on the floor of a round pit. It had most likely been wrapped in textile and was probably deliberately damaged before its deposition (Figs 5-6). ${ }^{9}$ The assemblage from Perevolotchna in the Ukraine, comprising twelve body, rim and mushroomshaped handle fragments of a cauldron, was published in 1994 (Fig. 7). The site lies on the left bank of the Dnieper, immediately by the confluence with the Vorskla River. The assemblage reached the Poltava museum from private collectors in the early twentieth century and was secondarily damaged when the museum burnt down in 1943. The cauldron came to light when a cellar was dug and the report mentions that several other fragments were found together with it. It is quite striking that the fragments reaching the museum were decorated almost without exception. This assemblage can be tentatively assigned to the category of complete cauldrons. It also seems likely that the cauldron had been broken into smaller pieces prior to its deposition. ${ }^{10}$

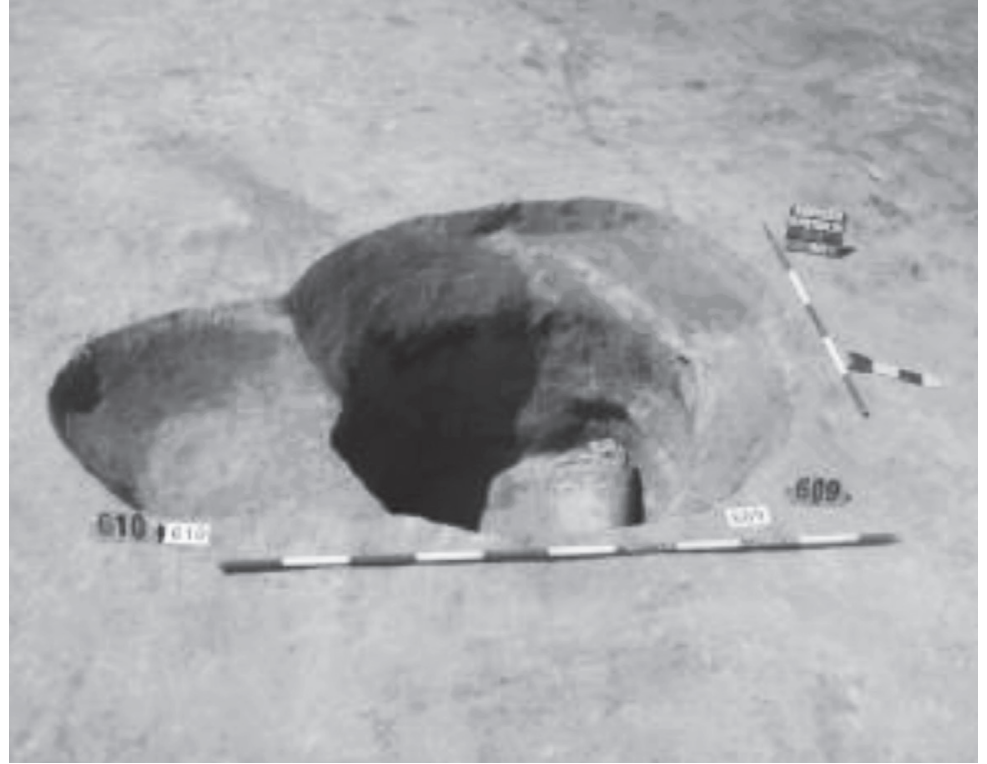

Fig. 5. The Rádpuszta cauldron, shown in situ (photo: Péter Németh)

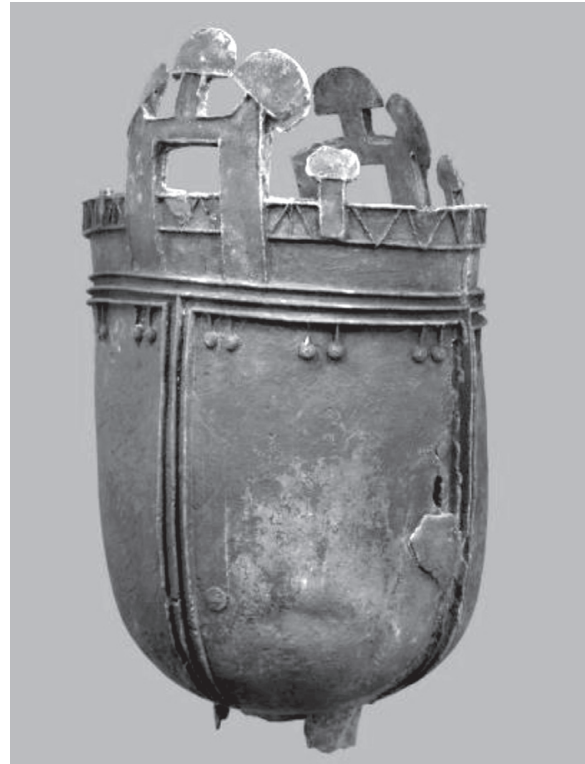

Fig. 6. The Rádpuszta cauldron (photo: Krisztián Balla)

Two new finds are known from the Kuban region in Russia. Three fragments of a Hunnic cauldron found on the outskirts of Buzhor, a settlement on the south-eastern edge of the Tamany Peninsula, were presented to the museum in 2013 (Fig. 8). The stray finds collected on ploughland were not accompanied by other artefacts. ${ }^{11}$ A Hunnic-type cauldron with rectangular handles came to light at Malai, a settlement lying north of the Kuban, in 1986 (Fig. 9). ${ }^{12}$ This find offers particularly important data on the use and deposition of cauldrons. The burial itself dates

${ }^{9}$ HONTI-NÉMETH 2007.

10 ЛЕВЧЕНКО-СУПРУнЕНко 1994, 77-81; KAZANSKIMastykova 2000, Fig. 4, 6-14. In earlier publications, the Russian name of the findspot was used (Perevolotchnaya). The settlement lying in a strategic location at the mouth of the Vorskla River, whose very name alludes to the fording place, played an important role from the Middle Ages. It was inundated after the construction of the Dnieprodzerzhinsk reservoir and is now submerged.

${ }^{11}$ НОВичихин 2014.

12 ЛИМБЕРИС-МАРЧЕНКО 2011. 


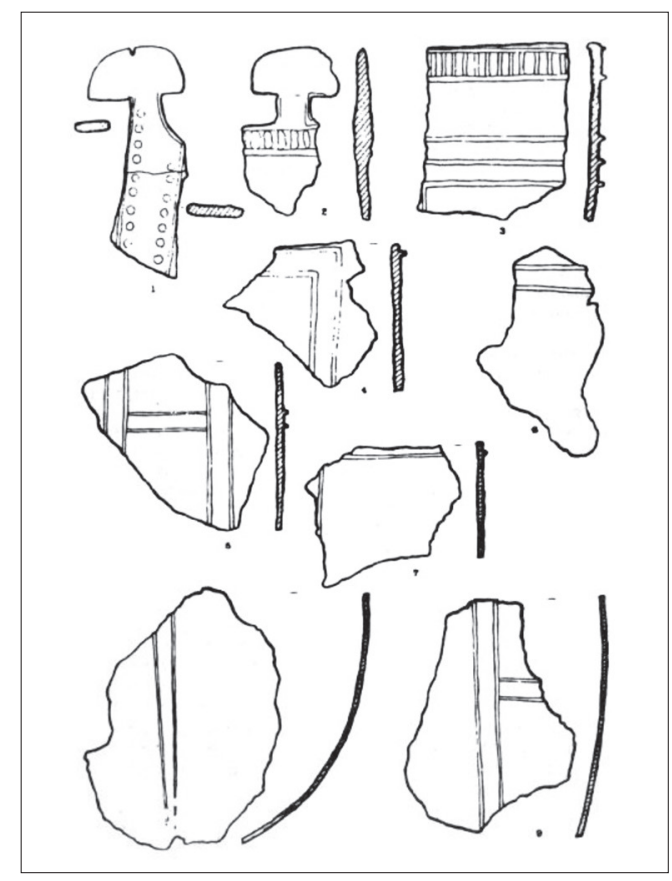

Fig. 7. Fragments of the Perevolotchna cauldron (after ЛЕвченко-СупРУненко 1994)

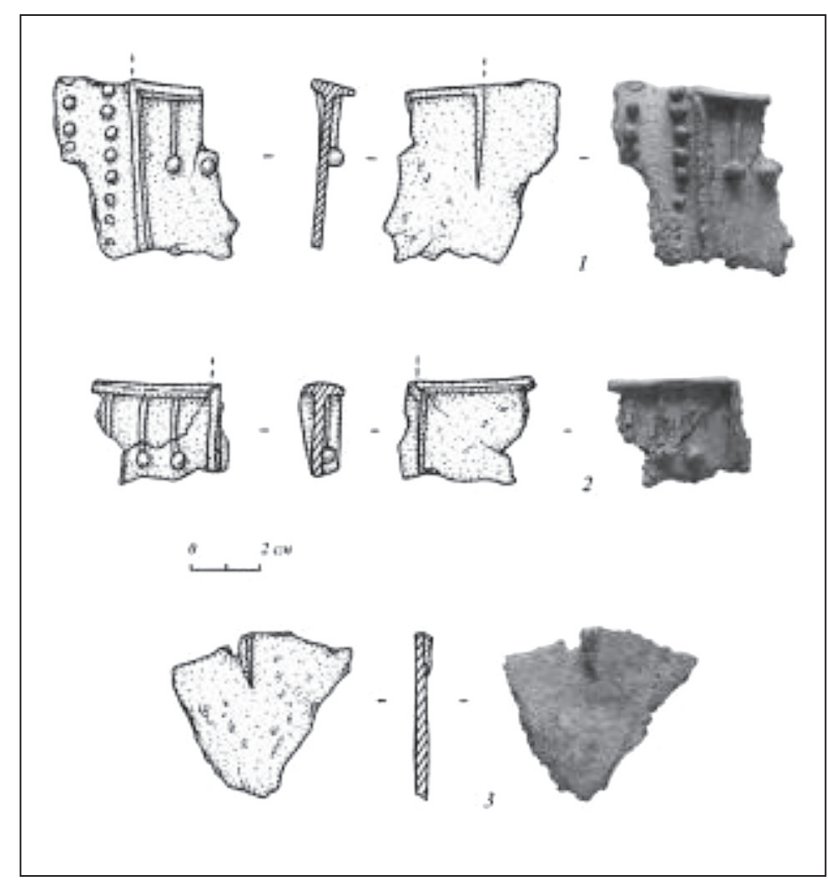

Fig. 8. Fragments of the Buzhor cauldron (after Новичихин 2014)

to the sixth century, although the association between the burial and the finds from the kurgan's earth cannot be proven. The Malai tumulus is one of a group of six kurgans, whose primary burial dates from the Early Bronze Age.

One of the interments dug into the kurgan's southern side was the burial of a man with artificially deformed skull (Grave 12, a ledge grave). The main finds from this grave were as follow: a sword with cloisonnéd cross-guard, P-shaped suspension loop, and chape, the bone stiffening plaques of a composite bow, plate armour, a silver belt set, silver harness ornaments, a bone saddle plaque and a gold earring. The tumulus was enclosed by a ditch, from which skeletal remains of thirteen horses and cattle skull fragments were recovered alongside grey pottery fragments, an iron artefact, a large bronze bucket and twenty-two fragments of a Hunnic cauldron. The cauldron had been broken into smaller pieces and some fragments lay in the ploughzone. ${ }^{13}$

A burial containing a Hunnic cauldron as a grave good was uncovered in 1995 in the northern Caucasus, in Ingushetia (Fig. 10), east of the Khabaz grave found earlier in the region. The Nasyr-Kort site lies on the outskirts of Magas (capital of Ingushetia): the grave itself lay some 400 meters from a fortified settlement (Nasyr-Kort 2). ${ }^{14}$ Found during road construction, the grave was partly destroyed by earth-moving machines by the time the specialists arrived. A part of the finds were collected from the workers, the locals and the dump. Although no more than six smaller fragments survived of the cauldron, ${ }^{15}$ the find circumstances suggest that the grave had possibly contained a complete cauldron. It seems likely that the grave had not been looted. The catacomb grave was sealed with a stone slab, which bore traces of metal patina, suggesting that it represented an imprint of the cauldron (or of some other metal artefact that was not found) and that the cauldron had been set at the entrance to the grave. Despite its unusual finds, the grave is linked to the local Alanic population and is dated to the last third of the fifth century. ${ }^{16}$

The Suncheleyevo cauldron (Fig. 11) was found farther to the north, in the forested steppe region of Tatarstan lying east of the Volga. Although the cauldron is strongly damaged, it can be assigned to the category of complete cauldrons. ${ }^{17}$ Another recently discovered cauldron is the first to have been found in southern Siberia, meaning that it is the easternmost piece if we disregard the cauldron from Nanshan in China. ${ }^{18}$ It was found at

\footnotetext{
13 ЛИМБЕРИС-МАРЧЕНКО 2011, 420.

${ }^{14}$ MaMAeb 2014, 55.

${ }^{15}$ Mamaeb 2014, ris. 4, 1-6.

${ }^{16}$ Mamaeb 2014, 63-64.
}

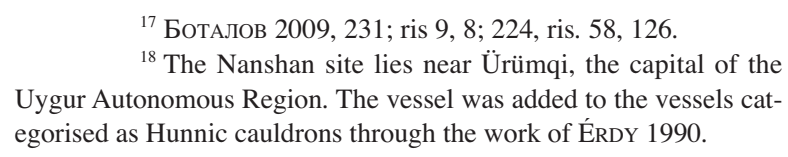

${ }^{17}$ БОтАЛОв 2009, 231; ris 9, 8; 224, ris. 58, 126.

${ }^{18}$ The Nanshan site lies near Ürümqi, the capital of the Uygur Autonomous Region. The vessel was added to the vessels categorised as Hunnic cauldrons through the work of ÉRDY 1990. 


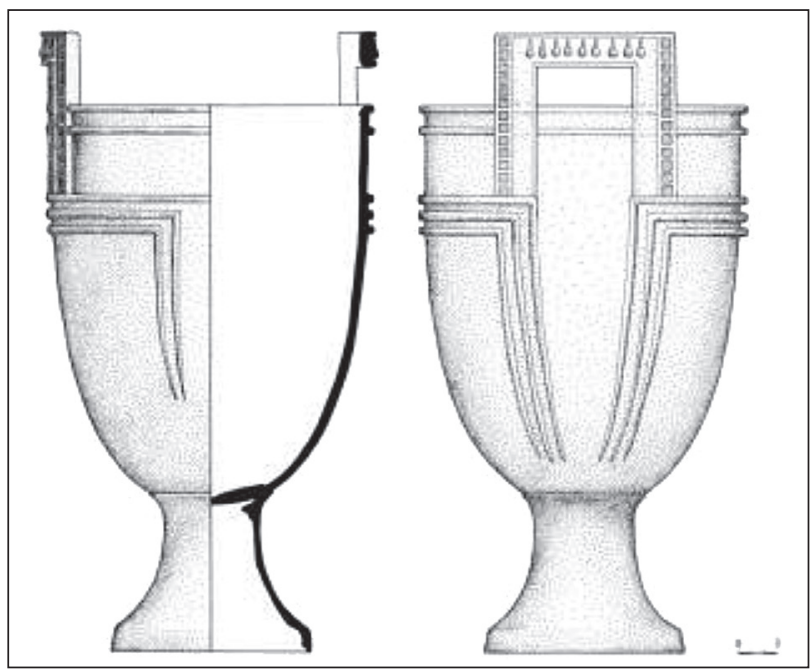

Fig. 9. Reconstruction of the Malai cauldron (after ЛИМБЕРИС-МАРчЕНКо 2011)

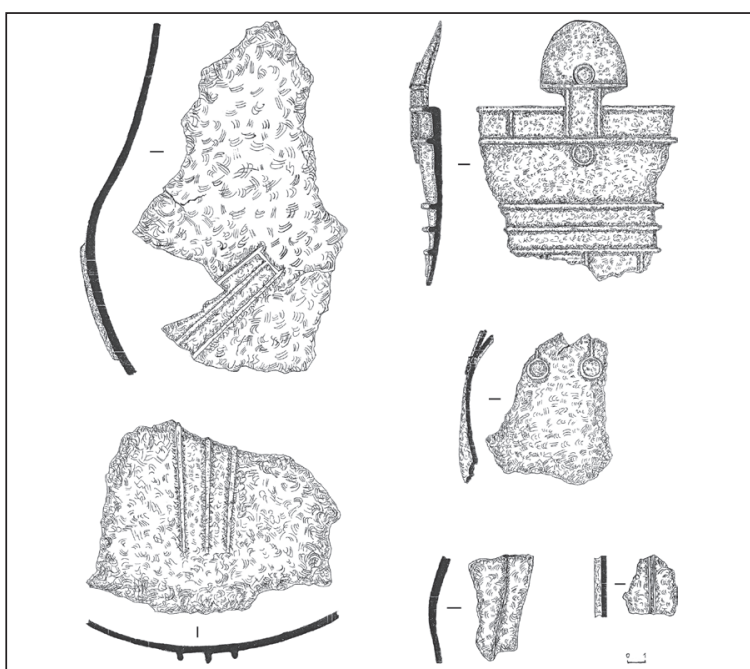

Fig. 10. Fragments of the Nasyr-Kort cauldron (after MAMAEB 2014)

Lipnyagova and it is similarly a complete cauldron of the Hun period (Fig. 12) ${ }^{19} \mathrm{~A}$ few new cauldron fragments have been recently published from Samara, all found immediately on the Volga bank. The assemblage, a stray find, comprises eight rim and body fragments of a cauldron (Fig. 13). ${ }^{20}$ The most recent find is known only from press releases: fragments of a large ornate cauldron found on the bank of the Don in the Volgograd area. ${ }^{21}$

\section{THE FINDSPOTS OF THE CONTROVERSIAL HUN-PERIOD CAULDRONS}

\section{"The cauldron from Gaul"}

The so-called cauldron from Troyes has the perhaps most curious history, calling for a detailed re-assessment of this find. ${ }^{22}$ Only so much was known about the findspot in the 1950s following a flurry of correspondence between Paris and Budapest, that soldiers had discovered it on the "Catalaunum Fields" while digging a trench during World War $2{ }^{23}$ This alleged provenance was never challenged by scholarship, despite the fact that it is virtually impossible to determine the exact place of the Battle of Catalaunum (or Mauriacum) fought in 451. The findspot was later variously located to French settlements (Chalon-sur-Saône, ${ }^{24}$ Troyes $^{25}$ ) or a smaller region (Champagne, ${ }^{26}$ Picardy $^{27}$ ). István Erdélyi later traced the provenance of this cauldron. The collector's widow confirmed the initial version of the findspot being the "Catalaunum Fields". However, the later owner had allegedly purchased the cauldron in Vienna complete with story about its provenance that made its way into both Hungarian and English papers during the past decades, even though the story was never really brought by Hungarian or international scholarship. ${ }^{28}$ The

${ }^{19}$ БОтАлов 2009, 231; ris 9, 7; 224, ris. 58,130 (east of the city of Shadrinsk)

${ }^{20}$ Кочкина-СТАшЕНКОв 2014, 41.

${ }^{21}$ http://newday.one/novosti-regiona/2460-v-volgogradskoy-oblasti-nayden-carskiy-kotel-gunnskogo-vremeni.html (last accessed March 15, 2016). The exact findspot of the cauldron was not revealed until the closing of the manuscript. According to the press release and the kind personal communication of Evgeny Kruglov, an archaeologist working in Volgograd, the findspot lay on the left bank of the Tsimlyansk reservoir, an artificial lake on the Don. It is here provisionally designated as the cauldron from "Volgograd" or "Tsimlyansk".
${ }^{22}$ TAKÁCs 1955, Abb. 1 a-b; SALIN 1967, Figs 2-3; ANKE 1998, Taf. 36, 5

${ }^{23}$ LÁsZló 1951, 102, note 70 (first mention); TAKÁCS 1955, 143-144. Salin described the findspot in similar terms ("sur le champ de bataille des champs catalauniques"); his source was the collector's widow (SALIN 1967, 387-389).

${ }^{24}$ WERNER 1956, 59, Kat. 17 ("Fundort apokryph") and, e.g., TeJRal 2011, 418.

${ }^{25}$ The latter can probably be attributed to TAKÁcs 1955 , 143, which was adopted, for example, by Ilona Kovrig (KovRIG 1972 106 , note 29 ).

${ }^{26}$ SALIN 1967, 388.

${ }^{27}$ Косн 1997, 638. 


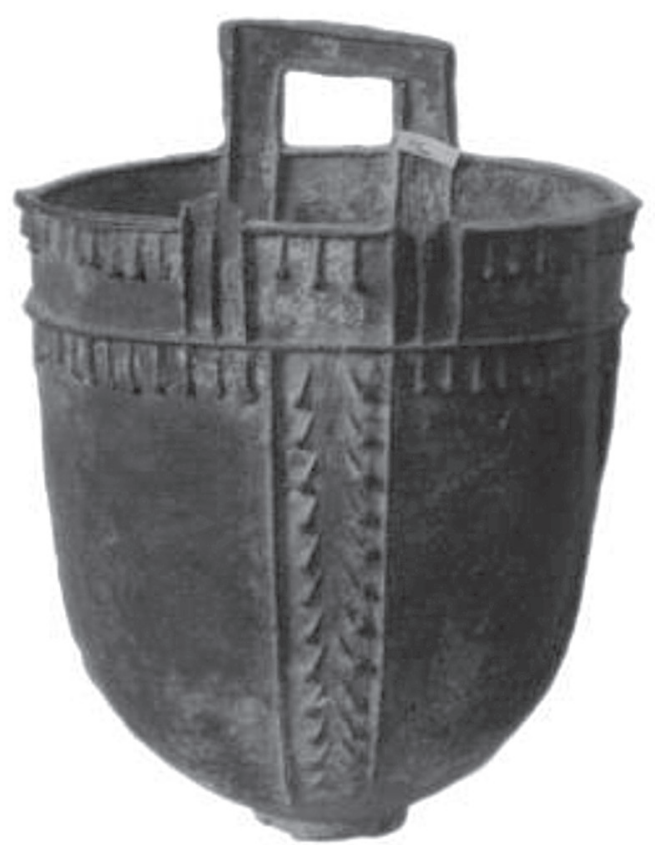

Fig. 11. The Suncheleyevo cauldron (after БотАлов 2009)

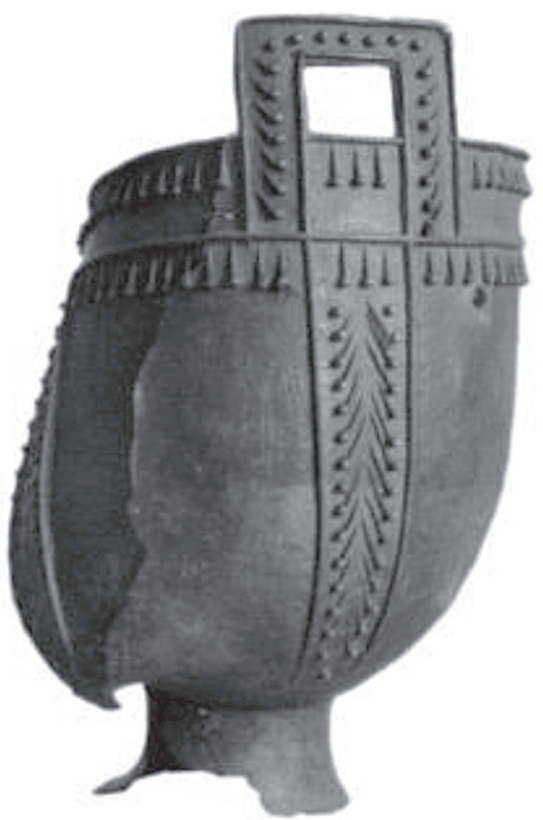

Fig. 12. The Lipnyagova cauldron (after БотАлов 2009)

key actor of the story is Prince Alfred Antonin Juritzky-Warberg, an Austrian art historian and collector, who had close ties with the auction houses of Vienna before World War 2. He later immigrated to France and died in Paris in $1961 .{ }^{29}$ Thus, one feasible explanation is that the cauldron originates from the Vienna antiquities market and that a "fanciful" background story was fabricated for its provenance, which proved impossible to untangle already during the wartime.

However, there is also a darker side to the story. It would appear that A. Juritzky was an active player on the art market during the war and he possibly also bought and sold archaeological finds. ${ }^{30}$

Knowing that he was forced to immigrate to France in 1938, it seems more likely that he had purchased the cauldron in Vienna before the war rather than after it because we know that the cauldron was already in his possession in 1950, or even earlier, in 1949. In this case, we cannot assume a shred of good faith on the collector's part. It is also possible that Juritzky merely wished to pursue his earlier business - in this case, the letter sent in 1950 was actually written with an eye to profit, to sell the cauldron to a buyer from whom the greatest gain could be expected, i.e. the Hungarian National Museum. The value of a "sensational" find from Gaul would obviously have been greater than of one from the Danube region. It is probably not mere chance that the Austrian contacts of the "Parisian" collector were wholly unknown to archaeological scholarship. ${ }^{31}$

${ }^{28}$ The information comes from the collector's widow, whom I. Erdélyi visited in Paris. He saw several other archaeological artefacts that in his view had originated from Austrian or Hungarian sites. For the first Hungarian report, see ERDÉLYI-SUGÁR 1982, 135136, for an English summary, see ÉRDY 1995, 17-18.

${ }^{29}$ Also known as Prince Alfred Antonin Kuritzki-Warberg, who can be identified with Antoine Jeritzki mentioned by LÁszLó 1951, 102, note 70, A. Juritzky is mentioned by TAKÁcs 1955, 143 144, whose widow was designated as Princess Juritzka by Salin. http://www.doaks.org/resources/bliss-tyler-correspondence/annotations/antonin-juritzky (last accessed March 15, 2016).
${ }^{30}$ According to BUCHMAYR 2011, following the occupation of France, Juritzky acted as a French agent and dealer of artworks to Nazi art collectors in Austria for a handsome profit; see also the sources cited in Petropoulos 1998, note 22, indicating that while living in Paris, he corresponded with Himmler during 1941 and 1942, with whom he bargained over the sale of German archaeological finds.

${ }^{31}$ In this case, Juritzky probably misjudged the situation in Budapest and the museum's potentials because Hungarian research was perfectly happy merely to publish the find. It is interesting to note in this context that the option to publish the cauldron was not even mentioned in the first letter (LÁszLó 1951); only a few years later was permission granted to Z. Takács to do so (TAKÁCS 1955). 
Despite these uncertainties, the cauldron fragment is still regarded as a piece from Gaul and only its findspot is called into question, if at all. ${ }^{32}$ This hardly resolves the problem: the renaming of the findspot from "Catalaunum Fields" to some modern place is highly speculative. Given the distribution of cauldrons, and the currently available information on this particular piece, it seems likely that this exemplar too originates from the Danube region, where several cauldrons have been found: from Hungary, Moravia or perhaps Austria - still, whichever the case, it does not significantly alter the western boundary of the cauldrons' distribution in Europe. A French provenance cannot be accepted as genuine and the piece in no way proves the appearance of cauldrons in Western Europe. It is therefore more appropriate to label this particular cauldron the "Vienna purchase". ${ }^{33}$

\section{Other finds with a controversial date}

The issue of the Sarmatian cauldrons from Brigetio (modern Komárom-Szőny) and Münstermaifeld representing different formal variants must be addressed in any discussion of Hunnic cauldrons since these were previously assigned to the category of Hunnic cauldrons and they are occasionally still dated to the Hun period. ${ }^{34}$ Joachim

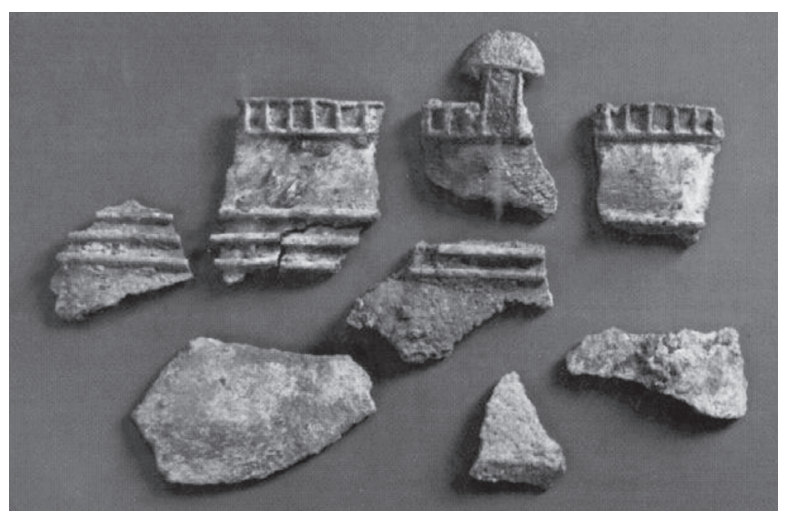

Fig. 13. Fragments of the Samara cauldron (after КочКИНА-СТАшЕНКОв 2014)

Werner correctly noted that these typologically earlier metal cauldrons had appeared in fourth-fifth-century burials in Asia, of which the most typical example is the Borovoye grave in Kazakhstan that he had cited. ${ }^{35}$ However, the two Sarmatian cauldrons found on Roman territory were stray finds. As has been pointed out in the re-assessment of the Münstermaifeld cauldron, cultural contacts can be demonstrated between the late Celtic and middle Sarmatian-period archaeological material in Eastern and Central Europe, meaning that the cauldrons could have been deposited at this time too. ${ }^{36}$ Thus, neither can be taken as conclusive evidence that these Sarmatian cauldrons had reached the West with the Hunnic migration or that they had been buried during the Hun period. Still, it would be inappropriate to disregard the Roman associations of these two pieces, given that both were found by the limes extending along the Rhine and the Danube: the former near an auxiliary fort, Confluentes (Koblenz), the latter near the legionary fort of Brigetio. However, this does not automatically imply Hun-period cultural contacts, even if the topographic location of their findspots makes a deposition in the Roman period more likely than in the Celtic period. ${ }^{37}$

Two earlier cauldrons, one from Stauropol, the other from Pokrovsk, regularly crop up in the archaeological literature since J. Werner's monograph, ${ }^{38}$ but they are now excluded from some discussions of cauldrons

${ }^{32}$ BÓNA 1979, 301; BÓNA 1984, 288; GHA 1987, 156; KAZANSKI 1993, 177, Fig. 3, 1 (Troyes); ЗАСЕцКАЯ 1994, 104 (France); КосH 1997, 631, 638, cp. ibid. 641, note 4; ANKE 1998, 140 (“Troyes(?)"); КосH 2007b, 288; RAJTÁR-ZÁBOJNíK 2010, 122; TEJRAL 2011, 346. I. Bóna suggested that the cauldron fragment came from the burial of Laudarich, Attila's relative, who had fallen in the Battle of Mauriacum (BónA 1991, 97, 140); elsewhere, he linked the cauldron to the Pouan assemblage, arguing that the cauldron had been used for presenting a sacrifice (ibid., 195).

${ }^{33}$ As, for example, ÉRDY 1995, 17-18, 69.

${ }^{34}$ WERNER 1956, 58. In more recent publications, e.g. ANKE 1998, 90 and 131, the cauldrons are dated to the turn of the fourth and fifth centuries and to the earlier fifth century (ibid., 48, note 281, with reference to other dating options). Cp. КоCH 1997, 641, note 4.

${ }^{35}$ For a critique of the arguments put forward by WERNER 1956, 57-58 ("Borovoye type"), see MAENCHEN-HELFEN 1973, 324
325. This context has been confirmed in the cauldron's new publication: ЯРыгин 2013.

${ }^{36}$ For a new publication of Münstermaifeld cauldron, see BEMMANN-OESTERWIND 1995. For the cauldron from Ószőny (modern Szőny, Hungary), see ALFöLDI 1932, 35, Taf. XVIII, 3a-b. The cauldron was included among the pieces submitted to metallographic analyses because its date was controversial; as it turned out, its metal composition differed substantially from that typical for Hunnic cauldrons (see KovrIG 1972, 116, 118-121).

${ }^{37}$ This assumption is not new; O. Maenchen-Helfen had already noted that the Münstermaifeld cauldron had been found among Roman ruins (regarded as the remains of a villa in the nineteenth century) and he believed that the cauldron could be explained by the settlement of Sarmatians in the Moselle region during the fourth century, as recorded in the literary sources (MAENCHEN-HELFEN 1973, 325). 
because their inclusion in the corpus of Hunnic cauldrons remains uncertain given the lack of any illustrations in their publications. ${ }^{39}$

Two other pieces which J. Werner had classified as Hunnic cauldrons ${ }^{40}$ are no longer assigned to this formal type. It must nonetheless be noted that, unlike Western research, Russian scholarship does not differentiate these pieces and other comparable finds from the European Hunnic cauldrons. ${ }^{41}$ In terms of typology, I shall not discuss these transitional forms in the following.

\section{THE FINDSPOTS OF THE HUNNIC CAULDRONS FROM HUNGARY}

\section{Törtel}

The findspot of the Törtel cauldron, discovered in 1869, is specified as Czakó-halom [Czakó mound], which can still be precisely located. István Bóna described the site as an "urzeitlicher Siedlungshügel" ${ }^{42}$ which would suggest a Neolithic or Bronze Age tell settlement in view of the region's archaeological past. Others have

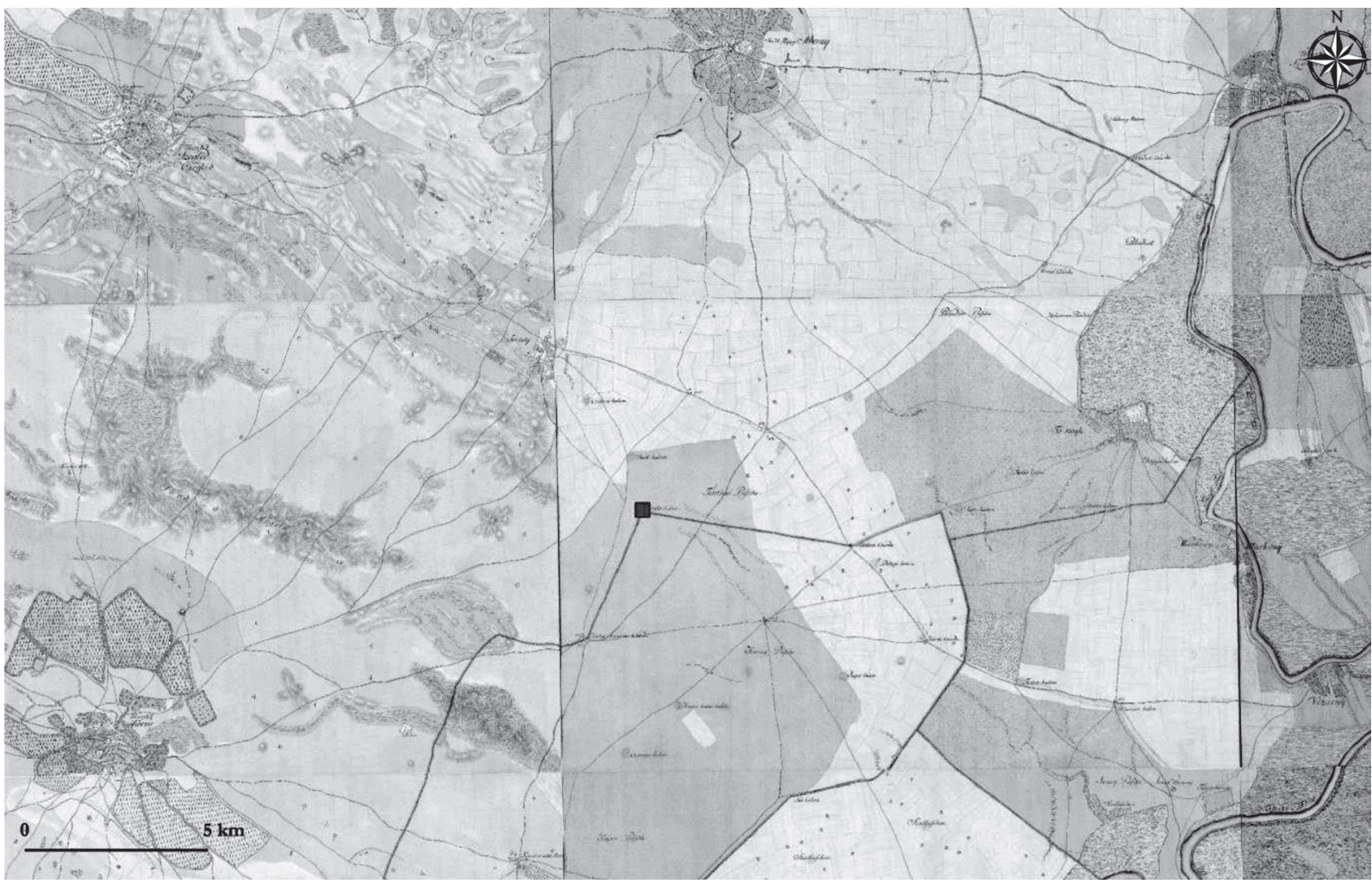

Fig. 14. The natural environment of the findspot of the Törtel cauldron on the map of the First Military Ordnance Survey (graphic: Zsófia Masek)

${ }^{38}$ WERNER 1956, 58-59. The rectangular handle is mentioned in the description of the Pokrovsk cauldron, and it was therefore assigned to this variant, e.g. KovRIG 1972, 108.

${ }^{39}$ E.g. Maenchen-Helfen 1973, 318, and КосH 1997 638, quoting him. Both pieces are mentioned, for example, by HaRhoiU-Diaconescu 1984, 101; ANKe 1998, Karte 4, 7 and 20; Vol. II, 37 and 120

${ }^{40}$ The Bijsk cauldron was made known to the period's scholarship by Aspelin and HAMPEL 1893, 398 and 397, Fig. 19, while the piece from Perm, based on Fettich's drawing, by TAKÁCS 1927,
146. Both pieces are mentioned by ALFÖLDI 1932, 34-35; later, e.g., FETTICH 1953, XXVI/11, 15; KovRIG 1972, 104, note 20. The findspot of the Bijsk cauldron is sometimes specified as Teletskoje in the earlier literature: TAKÁCS 1925, 211; the confusion concerning the findspot was clarified by MAENCHEN-HELFEN 1973, 316-317. It is obvious from the dimensions of the cauldron (H. $27 \mathrm{~cm}$, diam. 25-27 cm) that this piece represents another typological group.

${ }^{41}$ ZASECKAJA-BOKOVENKO 1994; ЗАСЕЦКАЯ 1994, 104 109; Figs 21-22, 24; БотАЛов 2009, 223-233, cp. ÉRDY 1995.

${ }^{42}$ BÓNA 1991, 141.

Acta Archaeologica Academiae Scientiarum Hungaricae 68, 2017 
described the mound as a kurgan. ${ }^{43}$ The size of the mound is indeed too small for a tell settlement and neither has it yielded any prehistoric finds. Thus, its classification as a tell can certainly be rejected; morphologically, it can more likely be seen as a prehistoric kurgan or a Roman-period tumulus raised over a Sarmatian burial.

The other problem is that I. Bóna regarded the "grey pottery sherds" found on the site of the Hunnic cauldron as dating from the Sarmatian period. ${ }^{44}$ This would be a crucial piece of information, but the initial reports on the cauldron do not specify the date of the pottery fragments presented to the museum together with the cauldron. The pottery sherds were first mentioned by Zoltán Takács, based on the acquisitions register of the Hungarian National Museum, ${ }^{45}$ which, however, did not specify their date and the pottery sherds can no longer be identified today. The excavation conducted in 1879, which focused on the region's prehistoric mounds, allegedly uncovered the remains of a medieval church and its churchyard on the Czakó-halom, but this piece of information is rather vague and neither was it confirmed by later field observations. ${ }^{46}$ Still, given that a medieval site could possibly be assumed at the findspot, the grey sherds in question could date from a much later period too.

Thus, the site may have some associations with the Sarmatian period in several respects (a kurgan burial or a settlement), but this can be neither confirmed, nor rejected based on our current knowledge. In this case, a more meaningful relation can be assumed between the site and the broader landscape, even more so, since not one single typically Hun-period site is known from the broader area.

I. Bóna attached particular importance to the location of the findspot of the Törtel cauldron on the fringes of the Tisza floodplain. ${ }^{47}$ The site indeed lies on the boundary between the sand region of the Danube-Tisza interfluve and the alluvial Tisza floodplain, and can pedologically be designated as the edge of the floodplain; however, a direct link between the area, currently partly cultivated and partly forested, and the river cannot be proven. Compared to the Ócsa site, the Törtel site lies closer to another route, namely the Budapest-Szolnok route that runs slightly more northward, which in antiquity represented the western section of the Aquincum-Porolissum road. ${ }^{48}$ However, a link between the site and the road is not as obvious as in the case of the Ócsa cauldron. The strategic role of the site thus remains uncertain (Fig. 14). Nevertheless, given the broader environment, it is feasible that the mound was a useful point of orientation visible from afar since it rises well above the surrounding plain and it is also possible that it was the setting for ritual activities (Fig. 15).

I. Bóna contended that the findspot lay on the fringes of the Hunnic centre on the Hungarian Plain, ${ }^{49}$ a claim that is essentially based on the historical sources. Given the location of the Ócsa site, the question arises as to

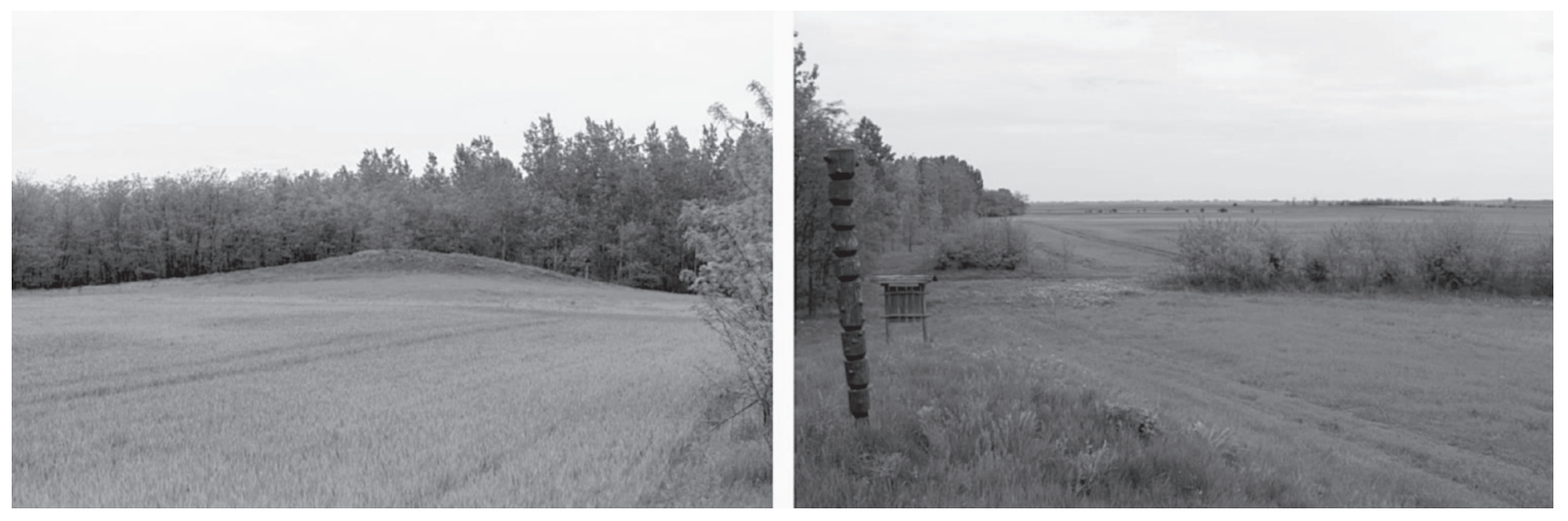

Fig. 15a-b. The Czakó-halom by Törtel (a), to the east (b) (photo: Zsófia Masek, May 3, 2015)

${ }^{43}$ E.g. TAKÁCS 1925, 206.

${ }^{44}$ BÓNA 1991, 275.

${ }^{45}$ TAKÁCS 1925, 207

${ }^{46}$ WÁGNER 1879, 366; PósTa 1896, 34-35; BALANYI 1973, 22. BALANYI 1973 , note 35 , assumes that the findspot was mixed up with a neighbouring mound, on which a churchyard can actually be found. Sarmatian-period vessel fragments in relation to the site are only mentioned in this case, but this piece of information also needs to be verified.

${ }^{47}$ BÓNA 1979, 301; BÓNA 1991, 141.

${ }^{48}$ Gabler-VADAY 1986, Abb. 21.

${ }^{49}$ BóNA 1979, 301; BóNA 1991, 141. Bóna argued that the same holds true for the Ioneşti cauldron, whose findspot lay on the western fringes of the Hunnic power base in the Buzău region (BóNA 
whether both sites marked the boundary of the Hunnic power base or whether we should seek another explanation for the locations. Is it mere chance that the findspots of the two cauldrons found on the Hungarian Plain lie so close to one another? These questions can only be answered after a more detailed examination of both finds.

\section{Kapos Valley between Högyész and Regöly}

The cauldron from the Kapos Valley is named variously in the archaeological literature. According to the original publication, it had been found "between Högyész and Regöly" in the valley of the Kapos Stream. The valley lies between the two villages and thus the association of the find with either of the two settlements is uncertain. ${ }^{50}$ The name of a third settlement also crops up sometimes, the village of Kurdcsibrák (modern Csibrák) near Hőgyész, in the opposite direction to Regöly. That the cauldron was allegedly found near the Kurdcsibrák railway station was erroneously claimed by Z. Takács; ${ }^{51}$ however, the contemporaneous reports do not support this village as the findspot.

One archaeological commonplace about the site is that it can be regarded as having a strategic significance since a major route led through the Kapos Valley during the Roman period. ${ }^{52}$ More recently, the role of this road has been strongly challenged. The reconstruction of the Pannonian road network indicated that there was no need for a southern Transdanubian diagonal road for administrative purposes, and neither do the written sources suggest the existence of this road. ${ }^{53}$ It would seem, then, that the site's immediate environment did not play a particularly prominent role in provincial topography.

The same does not hold true for the area's Hun-period topography. Despite their being known since long, a possible regional association between the findspot of the cauldron from the Kapos Valley and the Hun-period grave assemblages from Regöly ${ }^{54}$ and Murga ${ }^{55}$ has not yet been suggested. The territory of both settlements borders on the territory of Högyész from different directions. ${ }^{56}$ Archaeological assemblages or topographical locations whose significance is comparable to these three finds are not known from the Roman period from this small region, suggesting that the importance of the region had significantly increased in the Hun period. In view of its findspot, the cauldron can hardly be regarded as a solitary find from a micro-regional perspective.

The inland fort of Alsóhetény lies some $20-30 \mathrm{~km}$ west of these sites. A possible association between the fort and the cauldron was first proposed by Bóna - while there might indeed have been a link between the two, this yet remains to be proven. ${ }^{57}$ The fort lies in an entirely different geographic environment, open towards the north and south, and it would appear that its importance ceased after the turn of the fourth and fifth centuries. ${ }^{58}$ It is possible that the strategically important location was shifted to a more protected area.

1991, 141). In contrast, BÓNA 1987, 118, claims that the Törtel findspot indicates the location of the power base itself. In his earlier studies, he argued that Attila's seat lay south of the Maros River (BÓNA 1968, 114; BóNA 1984, 282; BÓNA 1991, 254), while in his later works, he opted for its location south of the Körös Rivers, in the Hódmezővásárhely area (BóNA 1987, 117; BóNA 1991, 64, 200). This latter view was obviously influenced by the discovery of the Szikáncs coin hoard. These localisations indicate that they are rarely based on the archaeological record and are thus irrelevant for further studies on the Törtel site.

${ }^{50}$ The findspot is specified as Högyész or "Kapos Valley": WOSINSKY 1891, 427; WosINSKY 1896, 986-992 (Pl. CLXXXXI); HAMPEl 1893, 396; HAMPEl 1905, 85; AlFÖLdi 1932, 34; FetTICH 1940, 246; FETTICH 1953, 40.

${ }^{51}$ TAKÁCS 1925, 208, and TAKÁCS 1955, 145; TAKÁCS 1959, 88, and, e.g., KovRIG 1972, 120, after him (Kurd railway station); MAenchen-Helfen 1973, 309. According to I. Bóna, the Hunnic cauldron's findspot was probably mixed up with that of one of the bronze vessels of the Bronze Age Kurd hoard, which also reached the museum during these years (BóNA 1991, 275).

${ }^{52}$ The road is tentatively marked as a Roman road on the map supplement to WosinsKy 1896; cp. also KovRIG 1972, 120

${ }^{53}$ Tо́тн 2006, 63-65. At the same time, Тóтн 2009, 53-54, assumed a regional south-to-north road (Sopianae-Iovia) running near the Alsóhetény fort.

${ }^{54}$ Mészáros 1970, and e.g. Attila 2007, 114-115.

${ }^{55}$ Wosinsky 1896, 994-995; 989, P1. CCXXXIX, and 991, Pl. CCXL; AlFÖLDI 1932, 49, 79, Taf. XXVI, 1-6.

${ }^{56}$ The village of Csibrák lies in another direction, to the south-west, in the Kapos Valley. The three locations are no more than roughly $10-15 \mathrm{~km}$ apart. A study of the area's topography in the fifthsixth centuries would no doubt be instructive since other major early Migration period sites are known within a radius of a few kilometres (Miszla, Tamási).

\footnotetext{
${ }^{57}$ BÓNA 1987, 118.

${ }^{58}$ То́тн 2009, 162-163.
} 


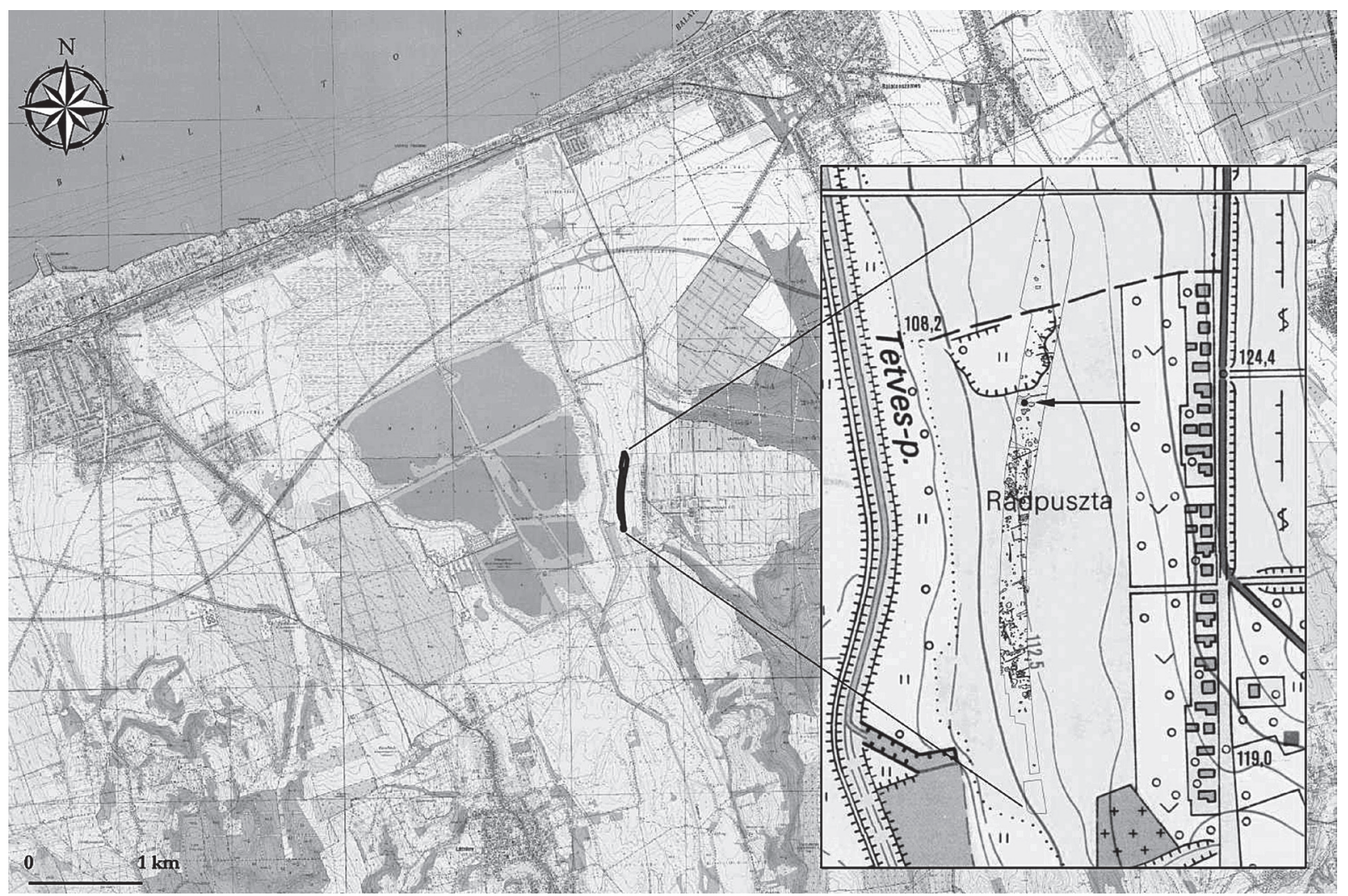

Fig. 16. The findspot of the Rádpuszta cauldron: the Roman vicus excavated at Balatonlelle-Rádpuszta-Temetőalja-dülő and Balatonlelle-Rádpuszta-Romtemplom mellett (Sites 67/4-5) and the location of Pit 609 containing the cauldron (geodesy: Archeodata, graphic: Zsófia Masek)

\section{Várpalota}

Topographic research identified traces of a Roman settlement near the assumed findspot of the Várpalota cauldron. ${ }^{59}$ A possible association with an inland fort, namely the Roman fort of Tác-Gorsium, was raised in this case too. ${ }^{60}$ The findspot allegedly lay in a marshy area, near water (see below for its significance). It must again be recalled that the find circumstances and even the findspot of the cauldron are wholly unknown because it was salvaged at the last moment from among copper-alloy metal scraps intended for re-melting, far from its findspot. ${ }^{61}$ Thus, any association between the cauldron and a Roman settlement, a strategically important location or the proximity of water to the findspot is speculative.

\section{Balatonlelle-Rádpuszta}

The Rádpuszta cauldron, recovered from the floor of a simple round pit in the course of a pre-development excavation, was described as a solitary find of the Hun period at the site in the admirably quickly published preliminary report. ${ }^{62}$ The preliminary report of the entire site and the plan of the site raise the question of whether the cauldron should be examined within the context of a late Roman settlement (Balatonlelle-Rádpuszta, Sites 67/4-5, Fig. 16). The Roman settlement at Rádpuszta was occupied between the first and fourth centuries, until the end of the Roman period. The pottery kilns uncovered on the settlement indicate craft ac-

\footnotetext{
${ }^{59}$ KovRIG 1972, 120; MRT 1969, 220, Site 49/43.

${ }^{60}$ BÓNA 1987, 118.
}

\footnotetext{
${ }^{61}$ KovRIG 1972.

${ }^{62}$ HoNTI-NÉMETh 2007.
} 
tivities. ${ }^{63}$ The greater part of the Roman settlement extended across Site 5 (Balatonlelle-Rádpuszta-Romtemplom mellett), while the pit containing the cauldron was found on the edge of the Roman settlement, on Site 4 (Balatonlelle-Rádpuszta-Temetőalja-dülö). Although the end of the settlement's occupation cannot be dated later than the fourth century on the evidence of the preliminary data, the metal finds recovered during the metal detector survey also included two cicada brooches, possibly dating from the Hun period. ${ }^{64}$ The end of the Roman settlement's occupation, its relation to the Hun period and the detailed assessment of the pit (which cut a Roman ditch) remain important issues for future research. What seems certain is an association between the cauldron's findspot and late Roman topography, similarly to the cauldron fragments known from Roman forts. ${ }^{65}$

\section{Intercisa}

The cauldron fragment from Intercisa is the single Hungarian exemplar that was discovered inside a Roman fort. (Since this cauldron, found in 1909, was the first in the series of finds recovered from similar contexts, it essentially determined the dating of cauldrons and their association with the European Huns. ${ }^{66}$ ) I. Bóna assumed that the cauldron fragment had been a sacrificial find deposited in a Roman building that had earlier been consumed by fire. In his view, the building had perished long before and that the Huns had occupied the fort and then lived there with their families(!) ${ }^{67}$ It has also been suggested that the cauldron came to light from under the debris of the burnt house. ${ }^{68}$ In fact, neither assertion can be proven.

The fate of the fort is closely intertwined with the interpretation of the cauldron and of cauldrons in general since the large-scale excavations in the Intercisa fort and the assessment of the site largely determined our understanding of the decline of the Valeria limes. I. Bóna had suggested already in the early 1970s that the fort had burnt down and perished around 425 and, consequently, he dated the cauldrons to after 425 or from the 430s on historical grounds. ${ }^{69}$ Mihály Párducz pointed out the uncertainties in this particular narrative of the destruction of the Intercisa fort and the dangers of a broad generalisation in 1974, and he also succinctly noted that the assessment of the (still) unpublished finds along these lines even contradicted Eszter Vágó's excavation report on Intercisa. ${ }^{70}$ László Barkóczi and Ágnes Salamon too challenged this interpretation from the perspective of Pannonia studies because in their view, the Roman and "barbarian" finds of the earlier fifth century could not be reliably separated and they also assumed that Roman crafts and industry had survived up to the mid-fifth century. ${ }^{71}$ Several controversial issues were also discussed by Péter Tomka. ${ }^{72}$ The most important point raised in these critiques was not the issue of dating, but the claim that an extensive burnt layer marked the end of the Roman fort's occupation in the fifth century. ${ }^{73}$ The Hunnic cauldron fragment assumed an important role in this debate, even though its find circumstances were not re-examined in detail.

${ }^{63}$ HonTi et al. 2007, 49-56; I am grateful to Ádám Dávid Hajdu for information on the site. The assessment of the Roman site is part of his doctoral thesis.

${ }^{64}$ HONTI-NÉMETH 2007, 72

${ }^{65}$ In the light of the above, the Rádpuszta cauldron refutes the earlier claim that complete cauldrons are not found on settlements (e.g. ANKE 1998, 52).

${ }^{66}$ TAKÁCS 1927, 228-229; ALFÖLDI 1932, 34-36; for further details on the research history, see BóNA 1991, 220-221.

${ }^{67}$ BÓNA 1979, 304; BÓNA 1991, 144-145; BÓNA 2000, 73 This view found wide acceptance, e.g. VIDA 2011, 637, and GoMOLKAFUCHS 2007, 215, and thus the interpretation of the Intercisa cauldron influenced and still influences the historical assessment of the cauldrons found along the Pannonian and Moesian limes. In contrast, Jaroslav Tejral based his account of the details on András Alföldi (TEJRAL 2010, 108, with the earlier literature). There is no evidence whatsoever that the mask-decorated mounts from Intercisa had been found together with the cauldron fragment (as suggested by BóNA 1979, 304).
68 TAKÁCS 1925, 209.

${ }^{69}$ BÓNA 1971, 267; BónA 1991, 262-263. Earlier, I. Bóna too had regarded the cauldron as a relic of the foederati dating to before 433 (BÓNA 1971b, 225).

${ }^{70}$ B. VÁGÓ 1971, 109-112; PÁRdUCZ 1974, 187-189.

${ }^{71}$ BARKÓCZI-SALAMON 1973, 91-93. The two last-quoted works were both written as a rejoinder to Bóna's 1971 study. O. Maenchen-Helfen too noted the uncertain dating of the end of Intercisa's occupation (MAENCHEN-HeLFEN 1973, 88). Cp. also SALAMON 1976, 207, 215.

${ }^{72}$ TOMKA 1996, 47.

${ }^{73}$ As a result of the debate, Bóna later discarded the idea that Valeria had been completely destroyed (BóNA 1991, 48-49), although the earlier narrative does crop up in other parts of his book: BóNA 1991, 178, Abb. 67; 262-263. According to a third, later explanation, Valeria had been ceded to Huns in an "empty" condition following the province's systematic evacuation (BóNA 2000, 71-74, after TóTH 1989). 
Antal Hekler published the findings of his excavation in Archaeologiai Értesító immediately after concluding his work on the site. ${ }^{74}$ It is quite clear from his report that his documentation contains virtually nothing about the stratigraphic relation between various features. Having an interest principally in classical archaeology and art history, Hekler focused on the groundplan of buildings and the inscribed stone relics, which he duly removed from the late Roman building foundations. The find material of his excavation can essentially be regarded as a collection of unstratified finds: only in the case of the more remarkable pieces did he record from which building they had been recovered. His report reveals that the "Scythian" cauldron fragment had been discovered in Room III of one of the buildings, but nothing more was recorded about the find circumstances. ${ }^{75}$

A. Hekler found a high number of Roman iron helmets in Room I of the same building ${ }^{76}$ from which András Alföldi assumed that the building had functioned as a military armoury prior to its destruction, an interpretation that gained widespread acceptance. ${ }^{77}$ Some Hungarian scholars writing before Bóna's studies contended that the cauldron fragment implied the presence of Hunnic troops in Roman service. ${ }^{78}$

In his report, A. Hekler makes no mention of any burnt debris layer in relation to the building sections he had uncovered in Antal Pozsgay's vineyard. ${ }^{79}$ In his report on the iron helmets published a year later, he notes that they were strongly burnt and that they came from an extensive burnt layer. This description was largely re-iterated by Lajos Márton in his overview of archaeological research in Hungary, although in his version, the entire building had burnt down. ${ }^{80}$ The extent of the burnt layer is thus wholly uncertain and the notion that the entire building had burnt down rather seems to be a later construct. At the same time, the burnt iron helmets suggest a strong local destruction. In the lack of any stratigraphic observations, it is impossible to determine whether the cauldron fragment had become buried at the time the building was still used or later; likewise, we can no longer establish whether it had been contemporaneous with the helmets and neither can its chronological relation to the building's destruction be clarified.

On the testimony of a bronze coin of Constantius II adhering to one of the helmets, the helmets were dated to the second occupation period in the monographic assessments of the early excavations ${ }^{81}$ However, several comparable helmet assemblages have since been found in Pannonia from various sites, which now tend to be interpreted as hoards rather than as an indication of a military armoury. ${ }^{82}$ The assemblage from the left-bank harbour fort at Dunafalva clearly shows that helmets of a similar type were used up to the late fourth-early fifth century in the region. ${ }^{83}$

Several pottery sherds that were earlier considered to be fourth-century Sarmatian vessel fragments were allegedly recovered from the building. ${ }^{84}$ The possible direct links of this barbarian material with the Hungarian Plain were not considered in later discussions of the fort's history, ${ }^{85}$ even though their re-examination might have a relevance for the interpretation of the cauldron.

The building in question lay in István Pozsgay's vineyard. A. Hekler uncovered the eastern side of a peristyle building and the western side of a similarly aligned other building to its east (Figs 17-18). According to István Paulovics, the peristyle building had a military function and had perhaps been part of the praetorium. (Obviously, the helmets played an important role in this interpretation.) On the testimony of the third-century stone relics incorporated into it, the building was erected or had been renovated in the fourth century. A. Hekler did not investigate

\footnotetext{
${ }^{74}$ HEKLER 1910.

${ }^{75}$ HeKLER 1910, 32, Fig. 2, marked as " $\pi$ " on the site plan.

${ }^{76}$ HeKLer 1910, Fig. 2, marked as "Q" on the site plan; HEKLER 1911.

${ }^{77}$ AlföLdI 1932, 34; e.g. TeJRAL 2011, 348.

${ }^{78}$ E.g. TAKÁCS 1925, 209, and TAKÁCS 1955, 153 (based on the evidence from Intercisa and Sucidava). For a broader, but contrary assessment, see ALFÖLDI 1932, 55-56. In I. Bóna's view, the helmets and the cauldron fragment could hardly be assigned to the same chronological horizon, and thus he did not take a stand regarding the helmets.

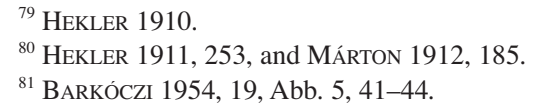

\begin{abstract}
${ }^{83}$ KoCSIS-MrÁv 2010, 200. For the dating of Intercisatype helmets, see also B. THOMAs 1971; Kocsis 2000; Kocsis 2008, 270; Miks 2014, 176-177.

${ }^{84}$ This is not a unique occurrence: according to the excavation report, Sarmatian-type material was found across the fort's entire territory during its 3rd period: BARKóCZI 1954, 51. This material certainly needs to be re-assessed and there are also some inconsistencies regarding the findspots of the pottery fragments. However, it seems likely from the information contained in the report that a part of the ceramic wares originates from the eastern side of the Danube: see BARKóCZI-ERDÉLYI I 1954, Pl. XI, esp. 1-4, 9, 11.

${ }^{85}$ Similarly to the cauldron fragment, Bóna had earlier linked the barbarian-type pottery from Intercisa to the foederati and had highlighted their resemblance to Cherniakhov pottery (e.g. BóNA 1971, 222-223); later, he regarded this pottery to have been produced in provincial workshops (e.g. BÓNA 1991, 262-263; BÓNA 2000, 71).
\end{abstract}




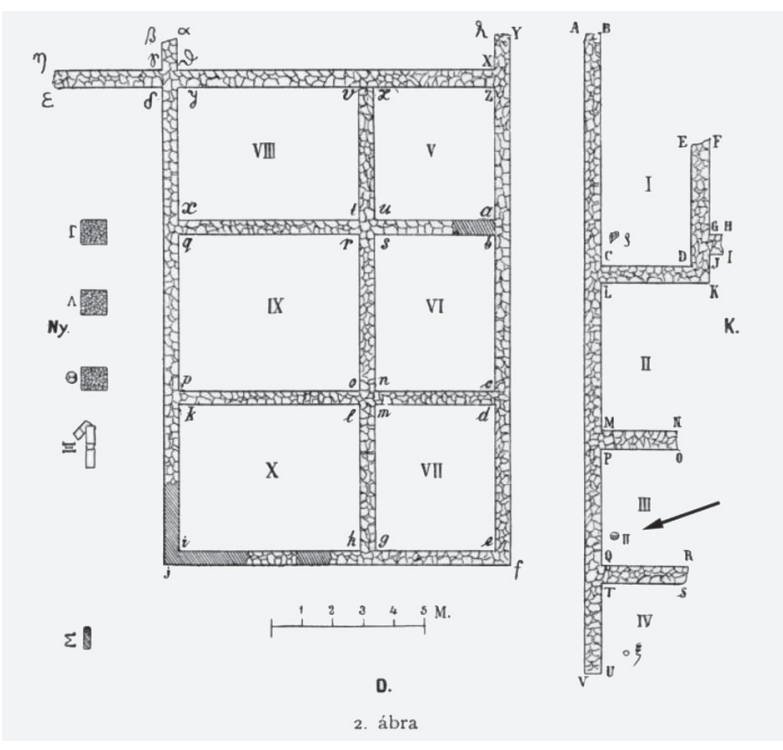

Fig. 17. Findspot of the Intercisa cauldron fragment (marked as $\pi$ ) (after HEKLER 1910)

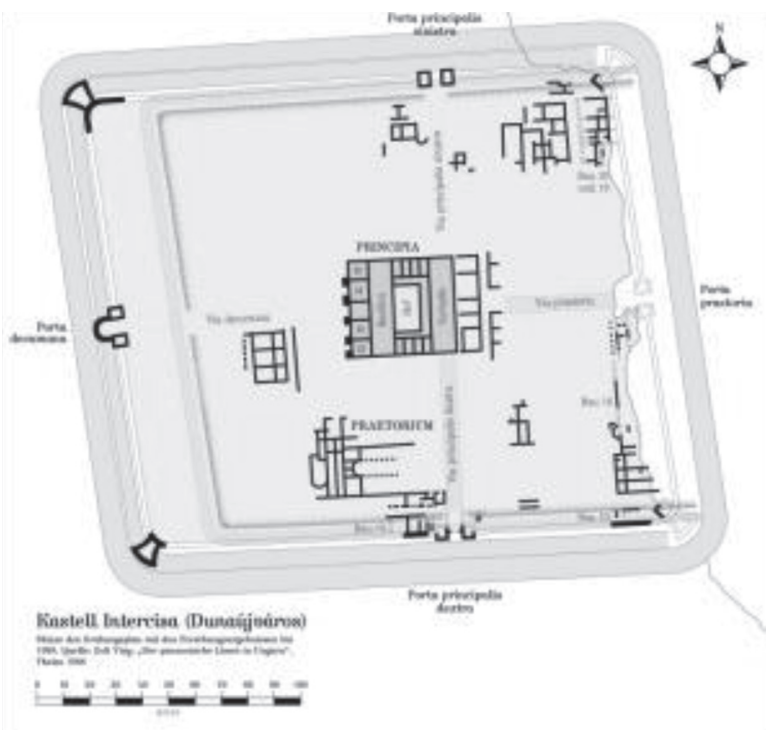

Fig. 18. Plan of the Intercisa fort

the building sections falling into adjacent fields and neither is there any new information about the groundplans of the buildings. The building in question lies along the via decumana in the retentura. The praetorium has since been uncovered on the fort's southern side. ${ }^{86}$ The function of the building from which the cauldron fragment was recovered thus remains uncertain.

According to recent studies, the last building activity in the fort can be dated to the reign of Gratian or Theodosius. ${ }^{87}$ Buildings erected on stone foundations that were no longer aligned to the fort's original layout and sunken buildings were both uncovered inside the fort. ${ }^{88}$ The upper chronological boundary of the fort's use as a military installation remains uncertain. ${ }^{89}$ The western and the southern cemeteries were still used during the early decades of the fifth century. ${ }^{90}$ The first reports dated their use up to the $430 \mathrm{~s}$, but this date is solely based on historical considerations, as discussed in the above. ${ }^{91} \mathrm{New}$ comprehensive studies suggest that burial in the cemeteries may have extended deeper into the fifth century. ${ }^{92}$

In addition to the fifth-century artefact types known from other late Roman cemeteries, ${ }^{93}$ other finds from Intercisa include types which according to the traditional ethnic attributions are associated with Huns (cauldron fragment and crescentic earrings ${ }^{94}$ ), eastern nomads or Germans (a girl's grave with cicada brooches ${ }^{95}$ ), Sarmatians

${ }^{86}$ Paulovics 1927, 24, Fig. 6, E; Barkóczi 1954, 19, Abb. 2. For the plan of the fort and the building based on an earlier reconstruction, see BARKÓCZI 1954, Abb. 8; for a reconstruction based on more recent research, see VISY 1988, 28, Fig. 11; VISY 2003, 117; VISY 2010, Fig. 7, 5; VISY 2011, 16. The building is known as Building 5 of the fort after SALAMON 1976, 213, Fig. 5 (according to the caption, it was made after BARKÓCZI 1954, Abb. 8, on which the buildings are still unnumbered).

${ }^{87}$ VISY 2003, 118. For an overview of previous research on the fort's late horizon, see BARKócZI 1954, 55-57; BARKócZI 1957, $535-544$.

${ }^{88}$ VISY 1977, 39.

${ }^{89}$ VISY 2003, 118

${ }^{90}$ BARKócZi 1957, 543-544; VÁGó-BóNA 1976, 205-206; $208-209$.

${ }^{91}$ VÁGÓ-BÓNA 1976, 209; BÓNA 2000, 73-74.
92 Bierbrauer 2004, 68-71; TeICHNER 2011, 277-278; VIDA 2011, 622, 629, 641. For a general discussion of the Romanised population's burials and the problems of burials without grave goods, See Bierbrauer-Nothdurfter 2015, 251-284, esp. 258-261, and BíRÓ-TOMKA, in print.

${ }^{93}$ E.g. polyhedral earrings VÁGÓ-BóNA 1976, 196-198, 208-209; for a discussion, see BARKÓCZI-SALAMON 1973, who did not accept the early dating of this artefact type; for the western Mediterranean material, see EGER 2005; for the similar finds from this region, see TeJral 2011, 228-231, and TeJral 2015, 321-323, who argued that these earrings first appeared in Pannonian cemeteries around 400.

${ }^{94}$ BÓNA 1991, 250 (unpublished, uncertain data).

${ }^{95}$ VISY 1981, 217. The best parallels to the cicada brooches found in the grave come not from the east, but from Suebian territory (ibid.), and the burial was earlier linked to the Germans, cp. VISY 1977, 39. 
(pottery), and the late Roman-Hun-period elite (bow brooches and a large buckle decorated with repoussé). ${ }^{96}$ Thus, on the testimony of the "barbarian" material too, the Intercisa fort was still occupied during the fifth century. ${ }^{97}$

The archaeological complexity of Intercisa during the Hun period is hardly surprising in the case of a Danubian fort facing the Sarmatian Barbaricum, as neither is the fact that the barbarisation of the material culture began already in the later fourth century. ${ }^{98}$ This must be borne in mind even if the impact of the foederati on material culture is wholly disregarded ${ }^{99}$ and we do not wish to offer a conclusive historical explanation for the phenomenon. As far as one of the main research issues is concerned, we may say that the entire barbarian-type material can be dated neither before, nor after 420/430, and that there is no good reason to assume a sharp break in the fort's life around this time. Irrespective of its exact date, the cauldron fragment can only be interpreted within this barbarised, many-hued late antique context. Its presence can only be assessed in greater detail once we have better anchors for determining the nature and the chronology of the fort's barbarian material.

As case studies, the cauldrons from Hungary are an excellent illustration of the intricate relationship between these finds and the late Roman- and Hun-period sites in their area, both within and beyond the borders of the Roman Empire. The possible relation of the findspots to the later Germanic period is much weaker and more uncertain, and can in some cases be wholly dismissed, as on the Hungarian Plain.

\section{DATING AND TYPOLOGY}

Given that the overwhelming majority of Hunnic cauldrons are stray finds, we can hardly speak of genuine typochronological studies in the case of these finds. Still, their topographic location and formal details are closely intertwined with their dating (Fig. 19).

Before embarking on a more detailed discussion of certain typological traits and of the cultural context of the Ócsa cauldron, it must be noted that some studies indicate that the currently known cauldrons reflect a gradual process of development and that this development can be linked to their westward spread from the east. At the same time, detailed studies have also shown that identical details can occur on cauldrons found at great distances from one another. The parallels spanning immense distances seem to contradict our general historical notions and it has therefore been suggested that in these cases we can perhaps assume Hunnic groups retreating to the east. In other words, cauldrons with more elaborate typological traits had perhaps been "taken back" to the east after the fall of the Hunnic Empire. Owing to these parallel cultural trajectories and the individual combination of ornamental motifs on each cauldron, the typological classification of cauldrons runs into several difficulties. ${ }^{100}$

\section{East to west development}

There is a general scholarly consensus that Hunnic cauldrons can be essentially divided into two main groups: one made up of the pieces with rectangular handles, the other of the exemplars with handles adorned with mushroom-shaped projections (designated as mushroom-handled cauldrons in the following). ${ }^{101}$ Variants with rectangular handles are generally regarded as being more archaic because these have generally been found in the easterly and northerly areas of the overall distribution of cauldrons (Verkhniy Konets, Soka, Jędrzychowice and the Olbia fragment). This distribution is also confirmed by more recent finds and we can now confidently claim that the cauldrons of the Hun period can be assigned to two typological groups whose distribution differs, even if there

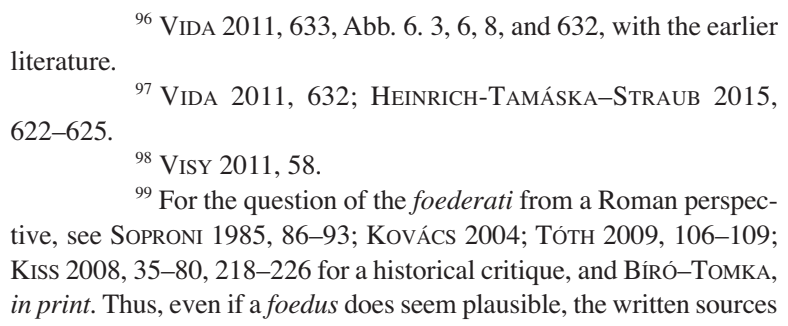

${ }^{99}$ For the question of the foederati from a Roman perspective, see Soproni 1985, 86-93; KovÁcs 2004; TóTH 2009, 106-109; KIss 2008, 35-80, 218-226 for a historical critique, and BíRÓ-ToMKA, in print. Thus, even if a foedus does seem plausible, the written sources

do not support the assumption that larger population groups were settled in specific areas, and thus the separation of their relics in the Pannonian archaeological material rests on very shaky foundations.

${ }^{100}$ For the literature on earlier typological studies, see ANKE 1998, 50 and note 288.

${ }^{101}$ E.g. Kovrig 1972, 104-106; ZaSECKAJA-BoKovenKo 1994, 710-711; ЗАСЕЦКАЯ 1994, 105-106; ANKE 1998, 50-51, also drawing attention to the similarities in ornamentation; SHCHUKINKAZANSKI-SHAROV 2006, 227; КосH 2007b, 287. 


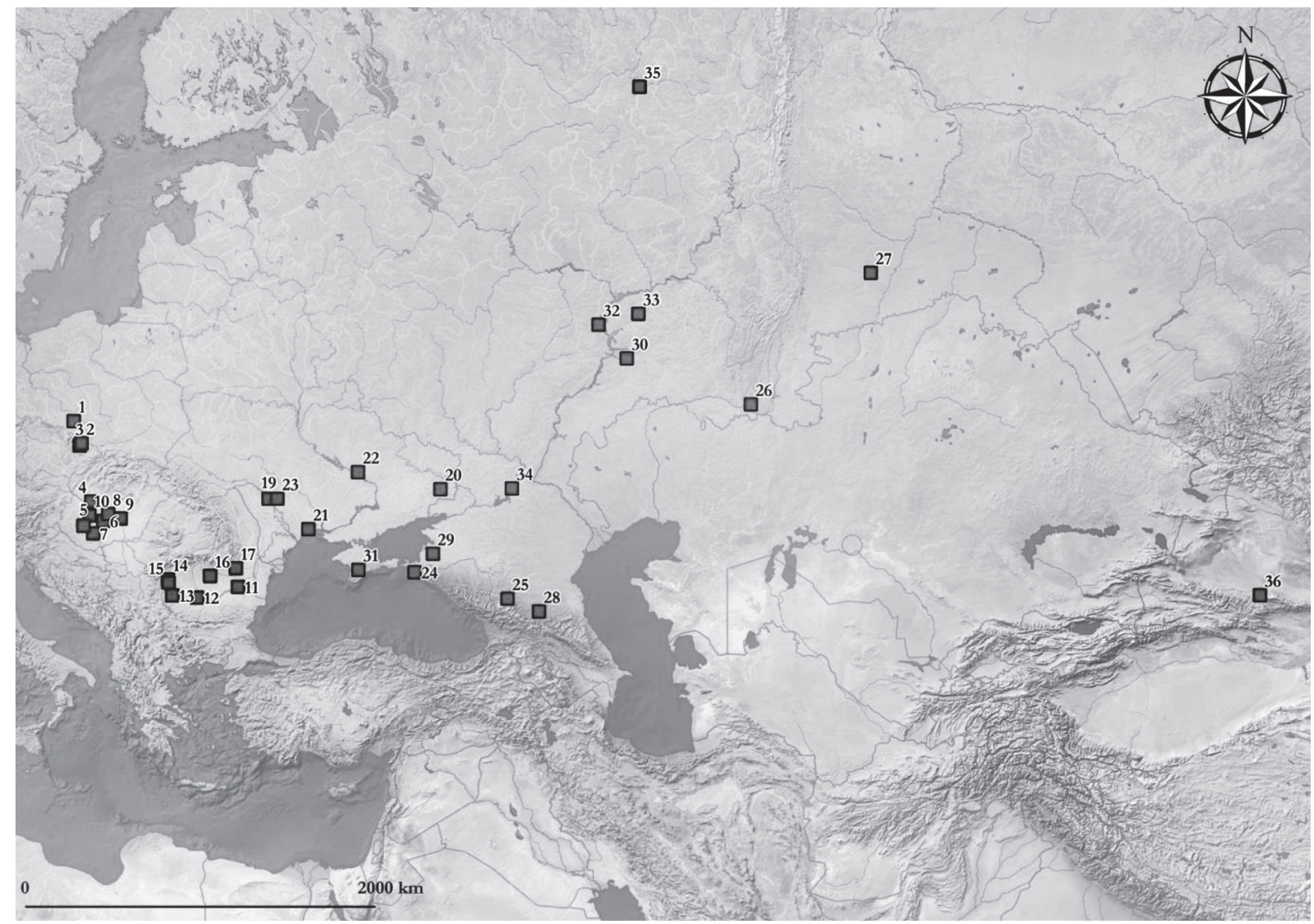

Fig. 19. Distribution of Hun-period cauldrons (the numbering of the sites follows that of the Catalogue; map: Zsófia Masek)

is a major overlap between the two. The cauldrons from Lipnyagova, Suncheleyevo and Malai can be assigned to the rarer type with rectangular handles and the fragments from Buzhor can likewise be assigned to this variant in view of its ornamentation. These cauldrons were principally distributed in the forested steppe region and to its north in the Volga region and southern Siberia, while the Jedrzychowice remains the single piece west of the Pontic (Olbia, Malai, Buzhor). ${ }^{102}$ The ornamental scheme of the newly found cauldrons resembles that of the earlier complete pieces (Verkhniy Konets, Soka) and the puritanical exemplar from Jędrzychowice remains unique in this respect. In view of their distribution and the probably late date of the Malai cauldron, it is possible that this variant was used simultaneously with the mushroom-handled pieces and that it merely represents a different workshop tradition.

Mushroom-shaped handles most likely appeared towards the close of the fourth century. ${ }^{103}$ The origin of this variant was initially tentatively located to the Lower Danube region or the northern Pontic littoral; at present, it is believed to originate from Inner Asia (see below). One of the most important, although less spectacular elements reflecting an east to west development is the change in the form of cauldrons, from the more archaic rounded shapes to the more elongated cylindrical pieces so typical for the Hun period in the Danube region. Radu Harhoiu distinguished three formal variants based on the height to diameter ratio. ${ }^{104}$

Even though the cauldrons from the Carpathian Basin and the Lower Danube region share several typological traits, ${ }^{105}$ it nonetheless seems that several Hungarian pieces represent the end of various variants in the typological sequence.

${ }^{102}$ REINECKE 1896. The Silesian find, known since long, was in Berlin until 1945; it is now housed in the Ermitage in St. Petersburg. See Europe without Borders 2007, 277; for the background, see ibid., 13-23.

${ }^{103}$ ANKE 1998, 53; Косн 1997, 632; Косн 2007b, 288.
${ }^{104}$ HarhoiU-Diaconescu 1984, 100; HaRholu 1997 $132-134$

${ }^{105}$ Kovrig 1972, 100-108; HarhoIU-DiacONESCU 1984, 100-106; BÓNA 1991, 145. 
The Törtel cauldron with its Baroque profusion of ornamental elements as I. Bóna so succinctly noted, remains the largest piece to date. The handle was divided in two by a vertical element decorated with cloison-like cells, perhaps owing to its large size. The cauldron was cast with a unique technology, from four moulds (Fig. 20). ${ }^{106}$ The Várpalota cauldron represents another formal development since it is the single cauldron on which a pair of mushrooms can be found beside the handles (Fig. 21). ${ }^{107}$ Quite uniquely, the fringe motifs are arranged in pairs on the shoulder of the Kapos Valley and Rádpuszta cauldrons (Fig. 22), while the Kapos Valley and Törtel cauldrons are linked by the cloison-like cell ornament under the rim. ${ }^{108}$ The Rádpuszta cauldron too has a cloison-like cells, although they are triangular and not rectangular as on the former two pieces.

\section{West to east connections}

At this point, we have to address some problems in the study of cauldrons, given that similarly to the Törtel and Kapos Valley cauldrons, two new pieces from the east found at Perevolotchna and Samara are decorated with rectangular cloison-like cells under the rim. ${ }^{109}$ The easternmost cauldron from Nanshan bearing alternating rectangular and triangular cells under its rim - a combination of the motifs known from the Carpathian Basin - can be assigned to this group too. It has been earlier suggested that the Şestaci cauldron, representing a visibly advanced phase of formal development, was the product of a western workshop ${ }^{110}$ and a similar origin was proposed for the Khabaz cauldron. ${ }^{111}$ The Vienna purchase handle fragment is regarded as the closest parallel to the Şestaci cauldron owing to the circular motifs on the mushroom-shaped projections. ${ }^{12}$ Yet another new find, the cauldron from a grave uncovered at Nasyr-Kort in the Caucasus, can also be assigned to this group: on this piece, the circular motifs appear both on top and at the base of the mushrooms. This piece, representing one possible end of the typological sequence, too reflects the direct links between the Danube region and the Caucasus. ${ }^{113}$

Differences in the form of the handles can also be taken as a starting point in classification. ${ }^{114}$ We can distinguish variants in which the upper curve of the handle is at right-angles (similarly to the cauldrons with a rectangular handles) and pieces that are curved. Cauldrons with curved handles appear over an extensive area. They include the piece from Kyzyl-Adyr, which is generally regarded as representing the transition between the Sarmatian and Hun-period mushroom-handled cauldrons. ${ }^{115}$ The variant appears in the Don region (Ivanovka) and in the Lower Danube region (Boşneagu, Desa, Hotărani, Ioneşti), ${ }^{116}$ while it is not attested in the Carpathian Basin; however, the cauldron from Benešov can also be assigned here. In view of the similarity with the Kyzyl-Adyr cauldron and the direction of the typological development, this variant can be seen as a relatively early one, ${ }^{117}$ even if its distribution indicates that it was used over a fairly long period of time, while the Lower Danubian exemplars represent a wholly developed form. Variants with three and four mushrooms can be distinguished among the cauldrons with angular handles, with the latter known only from the Danube region, suggesting that it can be deemed a late typological trait. ${ }^{118}$

The typological traits discussed in the above cannot be regarded as evidence for a linear development. The Kyzyl-Adyr cauldron, regarded as one of the forerunners, has curved handles, while the closest parallels to the cauldrons with rectangular handles, similarly considered an earlier typological group, can be found among the rectangular mushroom-handled pieces. The developed late forms are dominated by the latter, and the Hungarian

106 There is no evidence whatsoever that the cauldrons from Intercisa, Celamantia and Benešov had been made in a four-piece mould as suggested by BóNA 1991, 140, because the fragments are too small for drawing any conclusions regarding their manufacturing technique.

${ }^{107}$ KOVRIG 1972, 104.

108 ЗАСЕЦКАЯ 1994, 105; BÓNA 1991, 145.

109 ЛЕВЧЕНКО-СУПРУНЕНКО 1994, 79.

${ }^{110}$ Kovrig 1973, 108, 121; Harhoiu 1997, 131-133.

${ }^{111}$ БАТЧАЕв 1984, 258; ANKe 1998, 50. AnKe 1998, 54, note 313 , regards the Khabaz cauldron as a late variant taken to the east/south-east, similarly to the Nanshan cauldron. R. Harhoiu suggested a late date for the Şestaci and Khabaz cauldrons in view of their typological traits (HARHOIU-DIACONESCU 1984, 100; HARHOIU 1997, 132-134).

${ }^{112}$ Kovrig 1972, 108, 121; Harholu-Diaconescu 1984, 105; HaRhoIU 1997, 132; ANKe 1998, 50 (aside from I. Kovrig, the other scholars erroneously assigned the Törtel cauldron to this group).

${ }^{113}$ MAMAEB 2014, 62.

${ }^{114}$ HarhoiU-Diaconescu 1984, 105, Abb. 6; HarhoiU 1997, 131-132; ANKE 1998, 50-51.

115 ЗАСЕЦКАЯ 1994, 104; ZASECKAJA-BOKOVENKO 1994, 708; ANKE 1998, 49.

${ }^{116}$ Harhoiu-Diaconescu 1984, 105.

${ }^{117}$ Mitrea 1961, 552, 555.

${ }^{118}$ ANKe 1998, 51. 
cauldrons can be typically assigned to the rectangular variant irrespective of whether or not the handle is adorned with three mushrooms (Kapos Valley, Rádpuszta) or four (Törtel).

The easternmost cauldron from Nanshan cannot be considered as a typologically early piece. ${ }^{119}$ Based on the distribution of the currently known cauldrons, there can be no doubt that this cauldron reflects a west to east movement since even the closest sites (Kyzyl-Adyr, Lipnyagova) lie over $2000 \mathrm{~km}$ away. The best counterparts to the Nanshan cauldron are the pieces with curved handles mentioned in the above ${ }^{120}$ and the cauldrons with cloisonlike cells under the rim, principally the exemplars from the Carpathian Basin. At the same time, the decoration terminating in a triangular motif on the side compares well with a few pieces with rectangular handles (Soka, Verkhniy Konets), reflecting the fluid boundary between the two types. ${ }^{121}$

A few new cauldron finds similarly display a blend between the ornamental design of the two main types. The most recent find, a cauldron found in the Volgograd area, provides a specific link between the currently known pieces: this cauldron has classical mushroom-shaped handles combined with profuse ornamentation of the type appearing on the exemplars with rectangular handles known principally from the Volga region. The semi-spherical motifs appearing on the handles (and the mushrooms) are particularly typical of the cauldrons with rectangular handles. The Perevolotchna cauldron displays a more modest version of this hybrid ornamentation, with small spherical adornments on the handle in addition to the cloison-like cells under the rim. ${ }^{122}$ The Malai cauldron, representing a unique formal variant, has a rectangular handle decorated with rectangular cloison-like cells, a decorative motif hitherto appearing solely on the rim of mushroom-handled pieces and in the form of the "tamga"-like motif on the side of the Soka cauldron. ${ }^{123}$ It yet remains to be established whether these pieces mark the area where mushroom-handled cauldrons appeared, or whether they simply reflect a blend of two evolved formal types.

\section{Parallels to the tassel motif on the Ócsa cauldron}

The triangular tassel motif is an independent, new ornamental motif that lacks exact counterparts. Its two distinctive components can be examined separately. One is the triangular cloison-like cell, whose best counterparts can be found under the rim of the Rádpuszta cauldron and the easternmost Nanshan cauldron. Zigzag and triangular motifs are well attested on the Scythian-Sarmatian precursors, ${ }^{124}$ and possible Chinese forerunners have also been mentioned. ${ }^{125}$

The other component is the so-called pendula-motif. ${ }^{126}$ Most scholars agree that these motifs, imitating pendent fringes or tassels, can be derived from textiles or leatherwork. ${ }^{127}$ Their variants appearing on Chinese bronze vessels were last discussed by Z. Takács, which certainly warrants a fresh look at this subject. ${ }^{128} \mathrm{He}$ suggested, as early as 1925 , that the triangle motifs on nomadic cauldrons probably imitate tassels, similarly to their Chinese counterparts. ${ }^{129}$ Pendulas arranged into triangle motifs only appear on the Ócsa cauldron - in other words, Z. Takács's assumption, formulated almost a hundred years ago, is now borne out by the piece from Ócsa.

The most widespread variant is made up of a vertical line and a terminal ornamental motif. A similar decoration only covers the cauldron's shoulder in the case of the mushroom-handled variant, while on cauldrons with rectangular handles, this ornamentation often runs immediately under the rim and on the shoulder, in two rows (Soka, Suncheleyevo, Verkhniy Konets, Lipnyagova, Tsimlyansk, and probably Olbia and Buzhor), while on some pieces, it is arranged into diagonal rows coursing down the vessel body (Soka, Suncheleyevo, Lipnyagova, Tsimlyansk). ${ }^{130}$ Vertical fringe-motivs are set singly on the vessel shoulder, usually at greater distances on the shoulder

119 ZASECKAJA-BoKovenko 1994, 709; КосH 1997, 636; ANKE 1998, 50; KоCH 2007a, 144; for a contrary opinion, see ÉRDY $1995,16,45-46$.

${ }^{120}$ Koch 1997, 632; ANKe 1998, 54, note 311.

${ }^{121}$ These signs are generally regarded as tamga signs in Russian scholarship (БотАлов 2009, 229), whose earlier versions also appear on earlier Sarmatian cauldrons (Боковенко 1978, 228; КОСЯНЕНКО-ФЛЁРОВ 1978, 203-204).

122 ЛЕвЧенКо-СУПрУНЕнко 1994, 80.

${ }^{123}$ KovRIG 1972, 106

${ }^{124}$ KovRIG 1972, 104
125 TAKÁCS 1925, 221; TAKÁCS 1955, 155-156.

${ }^{126}$ WERNER 1956, 58; HARHOIU-DiACONESCU 1984, 105; MaEnCHen-Helfen 1973, 333; AnKe 1998, 49.

${ }^{127}$ FetTich 1940, 247-249; FetTICH 1953, 40-41; WeRnER 1956, 60; MAENCHEN-HELFEN 1973, 331-333.

${ }^{128}$ Some of Z. Takács's theories had already been rejected by András Alföldi, cp. AlFöLDI 1932, 35, note 57.

${ }^{129}$ TAKÁCS 1925, 221-222.

${ }^{130}$ ZaseckaJA-BoKovenko 1994, 711, emphasise the motif's close connections with the Volga group of cauldrons. 
of mushroom-handled cauldrons, while on the exemplars with rectangular handles, these motifs are set closely. The two exceptions are the cauldron from the Kapos Valley and Rádpuszta, on which fringes appear in pairs. We can distinguish vertical pendulas terminating in a ring (Kapos Valley, Törtel, Desa, Şestaci, Simferopol, Nasyr-Kort) and in a semi-sphere (Rádpuszta, Khabaz). The latter are typical for cauldrons with rectangular handles, suggesting that in terms of typology, this variant can be regarded as having stronger eastern associations.

The best parallels to the inverted triangle motifs adorning the shoul-

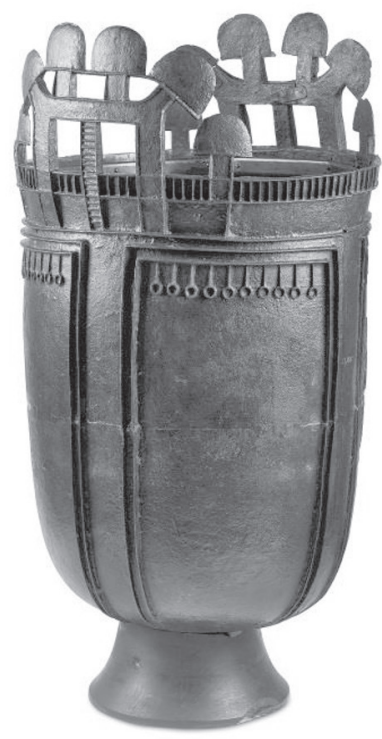

Fig. 20. The Törtel cauldron (photo: Ádám Vágó) der can be found on the cauldron from the Volgograd area. The motif is more elaborate on this cauldron than on the piece from Ócsa: the triangular motif was not created from pendula ornaments, but from two rows of semi-spherical bosses. Triangular motifs adorn the base of the sides on some cauldrons (Soka, Verkhniy Konets, Nanshan), perhaps representing the lower motif of tamga signs. ${ }^{131}$ The tips of the triangles on the Soka cauldron terminate in small semispherical bosses, ${ }^{132}$ an ornamental element almost identical to the one on the Ócsa fragment.

The above-quoted vessels decorated with pendulas generally have a triple rib around the shoulder, similarly to the exemplar from Ócsa.

The vertical ribs on these vessels are generally also arranged in bundles of three, ${ }^{133}$ as on the cauldrons from Rádpuszta and Intercisa as well as on the two fragments from Celamantia (modern Iža, Leányvár) among the pieces from the Carpathian Basin. The Kapos Valley cauldron has a single rib, an unparalleled feature among the Danubian cauldrons, which has no truly similar counterpart in the eastern material either. The Várpalota cauldron is the single piece that lacks the pendula motif, even though this is quite common on the mushroom-handled cauldrons in the eastern material.

In sum, the closest analogy to the Ócsa fragment is the Rádpuszta cauldron. Their shared traits (the triangular motifs and the semi-spherical bosses at the tip of the pendula) set them apart from the other Hungarian cauldrons and point towards the eastern pieces. At the same time, the Rádpuszta cauldron shares numerous similarities with the other Hungarian pieces (rectangular handles, cloison-like cells under the rim, fringe motifs arranged in pairs), which can probably be assumed in the case of the one-time Ócsa cauldron too, despite the uniqueness of its ornamental motif.

In addition to the clear-cut signs of a relatively swift process of transformation, it is also apparent that the regional differences we might expect among the cauldrons based on our interpretations of the historical record are not wholly borne out by the archaeological record. What we see, instead, is a cultural interaction between the regionally distinct groups rather than a linear development. This can be explained not only by the short duration of the time during which they evolved and were used, but also by the possible contemporaneousness of the finds. Thus, the cauldrons do not enable a more precise dating simply on typological grounds between the close of the fourth and the mid-fifth century. ${ }^{134}$

The pieces at the end of the typological sequence show a concentration in three regions: the Carpathian Basin, the Lower Danube region and the Caucasus. The possibility of a closer dating can be raised in the case of pieces that were accompanied by other finds. ${ }^{135}$ However, these cauldrons generally came to light on the fringes of the distribution territory (Jędrzychowice, Malai, Khabaz, Nasyr-Kort, Kyzyl-Adyr). In the case of the Caucasian pieces, a later, rather than an earlier date was proposed already in relation to the Khabaz burial. ${ }^{136}$ The Nasyr-Kort burial was assigned to the last third of the fifth century on the strength of the cloisonné disc brooch from the grave. ${ }^{137}$ The Malai cauldron from the Kuban region was quite certainly deposited well after the Hun period, even though it

${ }^{131}$ See above.

132 This detail was only highlighted by TAKÁcs 1925,222 , cp. the photo ibid., 209, Abb. 35 ("Otoka"); this detail is no longer apparent on the redrawn cauldron in the publications.

${ }^{133}$ For a detailed discussion, see KovRIG 1972, 106; HARHOIU 1997, 132; RAJTÁR-ZÁBOJNíK 2010, 120.

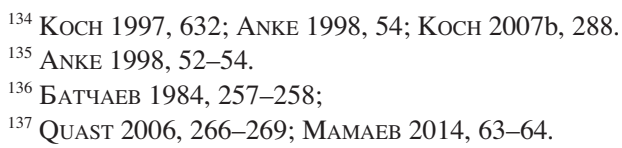

Acta Archaeologica Academiae Scientiarum Hungaricae 68, 2017 
represents an archaic type with rectangular handles. ${ }^{138}$ It seems that a sharp distinction cannot be drawn between the groups owing to the brief duration of time between the chronological boundaries. Still, the previous model of the gradual westward spread of cauldrons is no longer tenable and thus the distribution of Hunnic cauldrons, coloured by the inconsistencies outlined above, calls for another explanation.

\section{ORIGINS}

There is a consensus in the period's scholarship that the manufacturing technique of Hunnic cauldrons was grounded in an ancient eastern tradition that was wholly alien to European metalworking. However, most publications - in part understandably - were written without a detailed technological comparison of the finds and the construction of typological sequences was generally based on an assumed technological similarity. Thus, even though the issue of technology and origins cannot be separated theoretically, the two aspects need to be examined separately.

Previous scholarship linked Hunnic cauldrons to nomadic bronze vessels, to the long-lived Scythian and Sarmatian cauldrons distributed over an extensive territory, emphasising also the Central and Inner Asian connections of the steppe region. ${ }^{139}$ Hungarian research regards I. Bóna's opinion as the most authoritative on this issue too, according to whom the cauldrons represented the direct embodiment of Chinese and Inner Asian bronzeworking. ${ }^{140}$ In contrast to Z. Takács and A. Alföldi, he virtually excluded the finds culturally labelled Scythian, Sarmatian or Alanic from among the potential precursors, ${ }^{141}$ even though he too was unable to offer a convincing explanation for why mushroom-handled Hunnic cauldrons only appeared west of the Don (conforming to the then state of research). ${ }^{142}$

The theory of direct Inner Asian origins ("the Hsiung-nu connection") was proposed at a fairly early date, even though only a single similar cauldron was

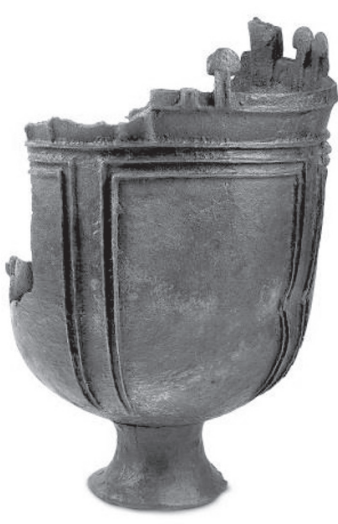

Fig. 21. The Várpalota cauldron (photo: Ádám Vágó) known from the Altai region, the Bijsk cauldron, which, however, is no longer classified as a Hunnic cauldron. ${ }^{143}$ Later, Z. Takács, ${ }^{144}$ J. Werner and I .Bóna ${ }^{145}$ added new finds from northern China and Mongolia to the ones already known to European scholarship, and the Inner Asian origin of cauldrons is now widely accepted in international research. ${ }^{146}$

\begin{abstract}
138 ЛИМБЕРИС-МАРЧЕНКо 2011, 431, the Soka cauldron is regarded as its best parallel.

${ }^{139}$ See, e.g., Hampel 1893, 396-400; ReineCKe 1896; TAKÁCS 1927, 146-148; TAKÁCS 1955, 147, for the Iranian and Chinese parallels of the cauldrons, see WERNER 1956, 58-59; ANKE 1998, 4849; cp. also TomKA 2007, 254-255, for the funerary rites of the Huns.

${ }^{140}$ BÓNA 1959, 41; BÓNA 1971, 269; BÓNA 1979, 301; BónA 1984, 288; BóNA 1991, 43-45, 140, 146. I. Bóna accepted the opinions of Z. Takács and Gy. László: the latter emphasised only the Inner Asian and Chinese cultural impacts, similarly to the long outdated idea that regarded the art of the Avar and of the Hungarian Conquest period as having originated from Inner Asia. See LÁsZLó 1946 (without any mention of cauldrons), and LÁszLó 1974, 36-40, on the art of the Huns.

${ }^{141}$ I. Bóna followed a similar line of argumentation in his
\end{abstract} studies on the Hun period regarding other issues too: he rejected any contact between the archaeological material of the Roman period on the Hungarian Plain and the Hun period, and accordingly dated a part of the archaeological finds to an earlier period than their parallels from other regions (see, e.g. BóNA 1991, 202, the Körösladány assemblage, and BónA 1991, 264, spouted jugs), or he simply neglected other relevant issues in his works. His belief that the cauldrons had a direct Chinese ancestry reflects a similar train of thought: Bóna rejected the continuity of the Eastern European late Sarmatian period with the Hunnic archaeological material, for which the archaeological arguments were based on the accentuation of the direct contacts with Inner Asia. The overall problem is illustrated by the fact that some of the grave assemblages cited by him were identified not as Hunnic, but as Sarmatian or Alanic finds in the archaeological publications he had also cited (to quote but one example: the Kispek chamber grave: BóNA 1991, 139, 176, 264-265, cp., e.g., KaZANSKi-MastyKova 2003, 42-44, 203; the grave can be dated to the late third-early fourth century).

142 BÓNA 1979, 305.

${ }^{143}$ ALFÖLDI 1932, 34-35; see also above.

${ }^{144}$ For an overview of his research, see BóNA 1991, 220-221.

${ }^{145}$ Werner 1934, 237; Werner 1956, 59; AltheimHAUSSIG 1958, 51 (quite exceptionally, virtually agreeing with J. Werner on this issue); BóNA 1979, 301.

146 ЗАСЕЦКАЯ 1994, 106-108, ris. 24; ZASECKAJABoKovenko 1994, Bemmann-Oesterwind 1995, 79; КосH 1997, 636; HARHOIU 1997, 134; LUTTWAK 2009, 14. 
Simultaneously, the model of a more westerly region of origin was also proposed at an early date, ${ }^{147}$ which is still encountered in some studies ("the Sarmatian connection"). ${ }^{148}$ The theory of Sarmatian origins has most recently been revisited by Bodo Anke, who rejected the Inner Asian origin of Hunnic cauldrons based on the distribution territory of their assumed Sarmatian forerunners and certain formal traits, and argued that the distinctive cylindrical Hunnic cauldrons had probably evolved in the region where the easternmost cauldrons were found, i.e. in the region marked by the Kyzyl-Adyr and Ivanovka cauldrons. ${ }^{149}$ The hybrid typological traits of the more recent finds from the Eastern European plain discussed above too indicate that Hunnic cauldrons underwent a major transformation in this region.

Thus, the typological sequences proposed for the development of Hunnic cauldrons is hardly a resolved issue. ${ }^{150}$ It must be borne in mind that there is a distinct possibility that earlier, Sarmatian-type cauldrons will appear among the late Roman-period grave assemblages of the steppe region. Although these ovoid Sarmatian cauldrons can hardly be regarded as immediate formal precursors, their affinity with the

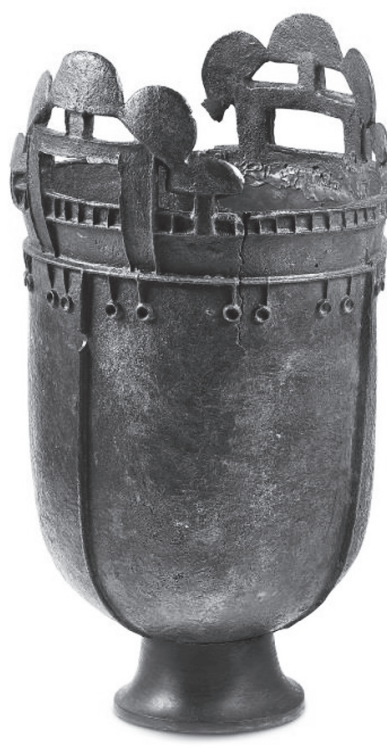

Fig. 22. The Kapos Valley cauldron (photo: Ádám Vágó) later Hun-period vessels cannot be denied. These vessels were used across the immense territory extending from the Volga-Don region to Inner Asia (Tuva, Ordos). ${ }^{151}$ The grave assemblage from Alt-Weimar (modern Vorontzovka, Saratov region) illustrates that these vessels were used in the late Roman period in the territory where Hunnic cauldrons later made their appearance.

The north to south oriented burial of a man with an artificially deformed skull was the central diagonal grave of a kurgan, which also yielded a sword with a pommel, which pointed towards the sword type labelled the Persian type by I. Bóna. ${ }^{152}$ Moreover, several examples can be cited of the use of even more archaic vessels on the Uralian-Kazakhstan steppe in the fourthfifth centuries, ${ }^{153}$ as exemplified by the Borovoye grave so often quoted in the western archaeological literature. ${ }^{154}$ The clay versions of small ovoid cauldrons with rectangular handles known from the Dzhetyasar regions were earlier believed to have been the forerunners of Hunnic cauldrons. ${ }^{155}$ However, their use has more recently been dated to the sixth-seventh centuries and thus they can hardly qualify as precursors to the Hunnic cauldrons, despite their formal similarities. It would rather seem that they represent an independent development in the Syr-Darya region. ${ }^{156}$

What seems certain is that Hunnic cauldrons can be regarded as a distinctive group among nomadic cauldrons: they appear quite suddenly and unexpectedly in the sense that they represent a formal variant that is dominated by a type that runs counter to the late Sarmatian developmental sequence and has a larger size range. ${ }^{157}$ Their best formal analogies are the Mongolian and northern Chinese cauldrons with openwork foot. However, a direct link with these cauldrons remains uncertain, in part for chronological reasons and in part because Hunnic cauldrons have not been discovered yet in this region. ${ }^{158}$ The typological group of Hunnic

${ }^{147}$ Fetтich 1940, 247-248; FetTich 1953, 40-42. I. Bóna rejected this model (BónA 1971, 269).

${ }^{148}$ ANKE 1998, 49, 52. The parallels from Tuva (Kokel) are mentioned in a Sarmatian context, contra BÓNA 1991, Fig. 43 ("vorhunnenzeitlich").

${ }^{149}$ ANKE 1998, 54-55. Disregarding the Chinese cauldron, conforming to the then state of research. The two vessels are quite similar, but the possibility that they had been made in the same workshop has been rejected (ЗАСЕЦКАЯ 1994, 105-106).

${ }^{150}$ TOMKa 2008, 97.

${ }^{151}$ Боковенко 1978, 234; for their distribution, see БОТАЛОВ 2009, 232, ris. 59.

${ }^{152}$ Werner 1956, 26-27, 57, 121 and Taf. 38; the site is also known as Staraja Ivantsovka (БотАлов 2009, ris. 58, 95 and ris. 59, 38); for the sword type, see BónA 1991, Abb. 12, 238-239.
${ }^{153}$ БОтАлов 2009, 228.

${ }^{154}$ ЯРыГин 2013. Cp. also note 35.

${ }^{155}$ ZASECKAJA-BOKOVENKO 1994, 711; 3АСЕЦKAЯ 1994 107; BÓNA 1991, 46, Abb. 15 and 241-242.

${ }^{156}$ БОтАЛОВ 2009, 227-229. Local clay imitations are known from farther east than this group, but these can hardly be regarded as forging a geographic link to the European regions (cp. ibid., and ZASECKAJA-BOKOVENKO 1994, 707-708; ÉRDY 1995, 25-27).

${ }^{157}$ БОТАЛОВ 2009, 229-231; ANKE 1998, 49.

${ }^{158}$ БОтАлОв 2009, ris. 58. The single link would be the Nanshan cauldron, but this piece comes from a more westerly region (eastern Turkestan), where the cited formal precursors have not been documented, not to speak of the fact that this piece is regarded as having been taken back from European territories (see above). 
cauldrons does not include a single piece that can be dated before the close of the fourth century, to before the Hun period, ${ }^{159}$ the implication being that, on the one hand, the model according to which these cauldrons gradually spread westward - which posits a direct link between the Hsiung-nu and the Hunnic material ${ }^{160}$ - seems unlikely, while on the other, the ethnic attribution of the eastern forerunners remains open. ${ }^{161}$

\section{MANUFACTURING TECHNIQUES}

For obvious reasons, the macroscopic examination of the Ócsa cauldron yielded no information on its manufacturing technique. Still, given the many erroneous claims, false commonplaces and uncertainties in the period's scholarship, its seems prudent to address this issue too.

The most detailed discussion of casting techniques was written by Imre János in relation to the Várpalota cauldron. ${ }^{162} \mathrm{He}$ reconstructed the casting of the cauldron as follows: first, a clay model of the body was made up to the crown conforming to the cauldron's intended volume, which was fired. Next, a positive mould was made of the cauldron's body from clay that was smoothed onto the fired core, which was then also fired; this was followed by the preparation of the external moulds, also from clay, which were fired after their removal from the core. The cauldron was then cast. The three openings on the interior base of the Várpalota cauldron were created with "clay stoppers" set in the mould before the casting procedure. These openings served for attaching the foot, which was cast immediately after the cauldron's body had been made.

Another reconstruction was proposed in the publication of the Ioneşti cauldron; however, the drawings illustrating the assumed casting procedure are not accompanied by a detailed discussion in the text. ${ }^{163}$ The drawings suggest the following procedure: first, the preparation of a clay model, after which the external mould was made, followed by the creation of an inner core that was fired separately. The decoration was made next, then the core was pared down to the cauldron's intended thickness. This reconstruction can be rejected. Future studies should take the reconstruction proposed by János as their starting point.

Ilona Kovrig's observations on manufacturing techniques have lost none of their relevance. ${ }^{164}$ She noted that the Törtel cauldron had been cast in four parts, while the other cauldrons had been made using two-part moulds, ${ }^{165}$ and that the foot of the Várpalota cauldron had been cast in a two-part mould. ${ }^{166}$ Similar observations were made in the case of the Romanian cauldrons. The casting seams on the foot of the Ioneşti cauldron, made in a two-part mould, are at $90^{\circ}$ to the cauldron's body. ${ }^{167}$

I. Kovrig noted that there are three pegs on the foot of the cauldrons (two oval openings on the piece from the Kapos Valley) for attaching the foot. ${ }^{168}$ However, we now know that this procedure was not general because the foot was attached in a different manner on the cauldrons from Romania. ${ }^{169}$

Pouring holes with a diameter of $8-12 \mathrm{~cm}$ can be found on the base of the three intact pieces from Hungary (as well as on the more recently found Rádpuszta cauldron). Previously, it was assumed - principally on the basis of the Törtel and Kapos Valley cauldrons - that the foot had been cast in one with the vessels, but had broken off. I. Kovrig correctly noted that these features on the cauldron bases can be explained by the casting technique and that the casting stubs were concealed by the foot after its attachment to the body. ${ }^{170}$ The consensus now is that the foot of the cauldrons became worn rather easily and eventually broke off, explaining why they are rarely found together with the cauldrons, although it has also been suggested that an alternate explanation for the lack of a foot is also feasible. ${ }^{171}$

\footnotetext{
${ }^{159}$ As noted by Косн 1997, 635, АNKE 1998, 53; БотАлов 2009 , 230. The Kyzyl-Adyr cauldron was earlier dated to the secondthird century, cp. Косн 1997, 641-642, notes 10, 12-13.

160 3АСЕЦКАЯ 1994, ris. 24; ZASECKAJA-BOKOVENKO 1994, 710 and Fig. 7; ÉrDY 1995, 52-53 and 67, Fig. 10. Cp. TомKA 2008, 91-92, 97.

${ }^{161}$ БотАлов 2009, 230-231.

162 "wiss. Mitarbeiter des Forschungsinstitutes für Eisenindustrie, Budapest" (KovRIG 1972, note 10).

${ }^{163}$ Harhoiu-Diaconescu 1984, 104, Abb. 4.
}

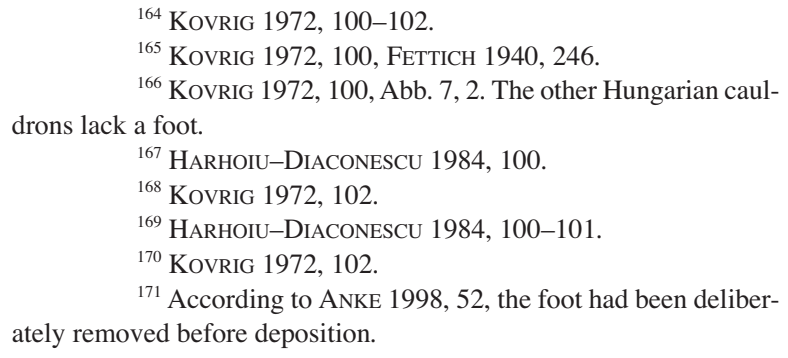


Aside from a few brief overviews of manufacturing techniques, ${ }^{172}$ there have been no studies on casting procedures since then. I. Bóna emphasised the direct Chinese links of the casting technology, even though he asserted that the cauldrons were cast in several pieces that were then soldered together and that the foot was riveted to the cauldron. ${ }^{173}$ Similarly to the question of origins, it is possible that parallel to the direct Chinese-Inner Asian technological ancestry, Hunnic cauldrons also had a direct association with the casting technology of earlier nomadic cauldrons, which was obviously also a technology adopted from another culture with more advanced metalworking. ${ }^{174}$ Thus, we should first identify the traits that can be regarded as "ancient Chinese traditions" because - aside from Bóna's misunderstood overview - this issue was never addressed in European scholarship. ${ }^{175}$

There were several casting techniques of eastern origin that did not employ lost-wax casting. These have various Scythian- and Sarmatian-period variants, and their relation to the Chinese- and the Hellenistic-based Central Asian traditions can be explored and studied. Still, it remains uncertain to which technological variant the Hunnic cauldrons can be linked or from which tradition they developed. ${ }^{176}$

Finally, one particular detail needs to be highlighted, namely that the wall thickness and weight of the cauldrons varies considerably. The wall thickness of the Ócsa fragment is $0.6 \mathrm{~cm}$, resembling most of the other Hungarian cauldrons, which have a similar wall thickness, while their weight is $16-20 \mathrm{~kg}$ and their height is generally $50-60 \mathrm{~cm} .{ }^{177}$ The Törtel cauldron is the largest with its height of $89 \mathrm{~cm}$ and weight of $35 \mathrm{~kg}$; in contrast, its wall thickness is smaller, no more than $3 \mathrm{~mm}$ (or $2-5 \mathrm{~mm}$ according to other descriptions). ${ }^{178}$ In contrast, the Şestaci cauldron has a wall thickness of $1.4 \mathrm{~cm}$ and a weight of $29 \mathrm{~kg}$, even though its height of $53 \mathrm{~cm}$ assigns it to the smaller variants of the average-sized vessels. ${ }^{179}$ These finer variations also have to be considered in detailed studies and reconstructions of casting technologies.

\section{METAL COMPOSITION}

The first metal analyses were performed on cauldron fragments from Romania, which indicated that they had been made from copper. ${ }^{180}$ It was pointed out that most cauldrons were described as being bronze vessels, despite the lack of metallographic analyses. ${ }^{181}$ Later, Otto von Maenchen-Helfen summarised the available analytical evidence on Scythian cauldrons, which indicated that these vessels had likewise been made of copper. ${ }^{182}$ He noted the varying quality of Hunnic cauldrons as described in the publications, for example in the case of the Jędrzychowice cauldron, in which the alloy was of such uneven quality, that the cauldron appeared to be of pure copper in some spots and of tin in others. ${ }^{183}$ The early descriptions of other cauldrons, such as the pieces from the Kapos Valley and Benešov, too suggested that they had been made from copper alloys with a high copper content. ${ }^{184}$ In line with the analytical results, these suggest that the cauldrons were not cast from recycled bronze artefacts and that they had been made by specialised metalworkers, similarly to the Sarmatian cauldrons. ${ }^{185}$ Regarding the source of the pure copper used for producing the cauldrons, O. Maenchen-Helfen emphasised the sources of the eastern forerunners, while R. Harhoiu contended that the Huns had also exploited the Carpathian ore deposits known in the Roman period for making the Lower Danubian pieces. ${ }^{186}$

${ }^{172}$ For a more detailed discussion, see MAENCHEN-HELFEN 1973, 319-323.

${ }^{173}$ This is probably based on Rómer's description (RÓMER 1870a, 291), and a misunderstanding of Kovrig's study (KovRIG 1972; see BóNA 1979, 301; GHA 1987, 156; BóNA 1991, 140, 275), which was then re-iterated by others (MÜLLER 2003, 287; Attila 2007, 145; ANKE 1998, 49)

${ }^{174}$ The similarities with late Sarmatian bronze casting were also noted by I. Kovrig (KovRIG 1972, 100).

${ }^{175}$ TAKÁCs 1925 discussed only the related features of ornamentation, but not of the technology.

176 This issue has an extensive eastern literature, which will not be discussed here since an assessment of the eastern contacts of the technology would call for a separate study. See, e.g. ДЕмидЕнко 2014a and ДЕмиденко 2014b.
177 Bóna 1979, 301; BóNA 1991, 140; HARHOIU 1997, 130 ANKE 1998, 49.

${ }^{178}$ PULSZKY 1891, 15; TAKÁCS 1925, 207. According to BóNA 1991, 275, it weighs $41 \mathrm{~kg}$, which is probably the current weight of the restored and reinforced vessel.

${ }^{179}$ НУДЕЛЬМАН 1967, 307.

${ }^{180}$ Mitrea 1961, 556-558. The fragments from Boşneagu and Sucidava were submitted to spectral analyses.

${ }^{181}$ Mitrea 1961, 552.

182 Maenchen-Helfen 1973, 321.

${ }^{183}$ MAENCHEN-HeLfen 1973, 321

${ }^{184}$ Wosinsky 1891, 427; KARger 1922, 30; KARGER 1940, 113.

${ }^{185}$ Maenchen-Helfen 1973, 323.

${ }^{186}$ MaEnCHEN-Helfen 1973, 322-323; and HarholUDiACONESCU 1984, 106. 
A study on the metal composition of the Hungarian cauldrons was published in $1972 .{ }^{187}$ The main conclusion drawn from the analyses was that the metal composition of the two cauldrons from Várpalota and the Kapos Valley was so similar as to suggest that they had been produced in the same workshop, and the Törtel piece was also highly similar. The composition of the Intercisa cauldron differed, but given that this was merely a fragment, the difference was attributed to the fact that a smaller number of measurements could be made than on the other exemplars. The analytical results differed from the findings of the measurements on the Romanian pieces in 1961, which lacked antimony, but contained several trace elements that were not present in the Hungarian pieces, from which I. Kovrig concluded that the cauldrons represented different workshop traditions. ${ }^{188}$ When writing about cauldrons made from different alloys in various workshops, Bóna based his arguments on these findings. ${ }^{189}$

The analysis of the Kyzyl-Adyr cauldron too indicated that it had been made from copper. ${ }^{190}$ The most recent study in this field published in 1984 discussed the metal composition of the Ioneşti cauldron. ${ }^{191}$ This analysis indicated a different tin and lead content than in the Hungarian pieces: the metal of the Ioneşti cauldron can be definitely identified as bronze. The findings of this analysis were not compared with the results of earlier examinations.

Thus, previous analyses indicated that the cauldrons had mostly been made of copper. The cauldrons are still often described as having been produced from bronze or, alternately, both options are mentioned and the question is left open. ${ }^{192}$

In the light of the above, the main questions regarding the metal composition are as follows from an archaeological perspective: is the claim that the cauldrons from the Carpathian Basin and the Lower Danube region have a different composition still valid? Can the material of the cauldrons be labelled an alloy and if so, what kind of alloy?

The XRF and SEM analysis of the Ócsa cauldron indicated that the cauldron had been cast from pure copper with a $1 \mathrm{w} / \mathrm{wt} \%$ lead content (see the Appendix). This composition would suggest that lead had been added intentionally; however, further studies are necessary to confirm this. This metal composition can be assigned to heavy coppers in today's classification, even though it can hardly be correlated with modern categories. The metal composition of the Ócsa cauldron corresponds to that of some of the pieces from the Lower Danube region (e.g. Boşneagu and Sucidava), bur differs significantly from the composition of the Ioneşti cauldron.

\section{THE ASSOCIATION OF THE FINDSPOTS WITH WATER - CHTHONIC SACRIFICES IN THE HUN PERIOD?}

The hypothesis that cauldrons and their fragments were found immediately beside rivers, lakes and marshy areas has since long occupied a prominent place in the period's scholarship. Proponents of this supposition emphasising the association with water assumed that this reflected ritual practices related to water and that the findspots can be regarded as the locations where the rituals had been performed. ${ }^{193}$ This theory contradicts another widespread assumption, namely that Hunnic cauldrons had been funerary sacrifices, as illustrated, for example, by Bóna's categorical rejection of the theory ${ }^{194}$ However, most studies tend to adopt a blend of the two, even though they usually accentuate the point that the little that is known of find contexts is unsuitable for a more comprehensive assessment. ${ }^{195}$

${ }^{187}$ Kovrig 1972, 122-125.

${ }^{188}$ Kovrig 1972, 114

${ }^{189}$ BÓNA 1991, 145 .

${ }^{190}$ ГАРяИнов 1980, 261; also mentioned by HaRHOIU 1997, 130.

${ }^{191}$ HaRHoiU-DiaCONESCU 1984, 115-116. Spectrographic analysis (115, Beilage 2$)$ as well as neutron activation analysis and XRF (116, Tabelle 1).

${ }^{192}$ E.g. BónA 1991, 43: "gegossenen Kupfer- und Bronzekessel”, and КосH 2007b, 287: "aus Bronze oder allgemeiner einer Kupferlegierung".

${ }^{193}$ In the following, I shall discuss the contexts of those cauldrons that were found in locations close to water according to MAENCHEN-HelFEN 1973, 329-330; HARHOIU-DiACONESCU 1984, 106 and Abb. 6; КосH 1997, 638-640 (Fundliste); HaRHOIU 1997, Taf. CV
(Kombinationstabelle); ANKE 1998 (catalogue). See also NestorNicolaescu-PlopŞOR 1937, 180-182; Werner 1956, 60; HarhoiU 1997, 130, 133

${ }^{194}$ BÓNA 1991, 240. This theory never took root in Hungarian scholarship and was not adopted in the works written for the broader public either (with the exception of TAKÁCS 1959, 87-89). One reason is perhaps that it did not fit into the overall picture since the possible practice of rites or the vestiges of mythical traditions associated with water were never raised in archaeological, historical or ethno-archaeological studies on the population groups of eastern ancestry (such as the Scythians, Sarmatians, Huns, Avars, Hungarians, Cumanians) which played a role in the ancient history of the Carpathian Basin. For the rites of the European Huns, see ToMKA 1986, TOMKA 1987; ТомКА 2007.

${ }^{195}$ ANKE 1998, 51. 
One case illustrating how this conjecture was overblown out of all proportion is that a similar context was assumed for the "Troyes" cauldron, even though it has a highly dubious provenance.

The stray finds include several pieces whose findspots can be currently associated with water or wetland, but an association of this type is wholly uncertain regarding the location in Antiquity. The above hypothesis probably played an important role in highlighting the role of water in the case of other cauldrons.

\section{A review of the findspots}

The fragment from Benešov found in 1907, whose association with a marsh was suggested later, can be assigned to the latter group. ${ }^{196}$ However, the initial publication clearly stated that the fragment had been found in a woodland environment during road construction, perhaps during ditch digging, at a depth of 25-40 cm, and that it was not accompanied by other finds. ${ }^{197}$ A peaty soil is mentioned by Viktor Karger in his article describing the findspot in more detail, which was written in knowledge of the Romanian theory, published in 1937. He mentions that the findspot lay in an area covered with black peaty humus and grass. ${ }^{198}$ In a study published at the same time, Georg Raschke noted that while there were no peat remnants on the cauldron fragment, remains of brown clay could be identified. The report of the official who had found the fragment discarded under a tree in a secondary position after the completion of the construction work and had presented it to a private collection recorded that he had cleaned the fragment of the brown clay covering it. Georg Raschke concluded that the fragment was not found beside the road, but on a nearby hill known as Schanzenberg, where clay for the construction had been mined (Fig. 23). ${ }^{199}$ Because the original finder of the fragment could no longer be tracked down - the road builders came from Italy - and because all that we know about the fragment post-dates its actual discovery, the findspot and the find context can no longer be accurately reconstructed.

The find circumstances of the Várpalota cauldron are wholly unknown and its association with water cannot be proven. ${ }^{200}$ Although Mór Wosinsky wrote about "Kapos Valley peat" in the case of the cauldron found there, the vessel itself came to light during ploughing in the stream valley. ${ }^{201}$ Since nothing else is known about the find circumstances, it remains unknown whether the cauldron's findspot lay on the one-time stream bank, in the stream's channel, or in a location that was also suitable for settlement on the stream bank. Regarding the findspot of the Törtel cauldron, I. Bóna highlighted that the findspot was located on the fringes of the Tisza floodplain and this remark was then repeated in the publications emphasising the ritual role of water. ${ }^{202}$ The findspot actually lies some $15 \mathrm{~km}$ from the Tisza and thus a direct association between its deposition and the river can be rejected (Fig. 14).

The Desa cauldron was retrieved during fishing at the time of the Danubian floods in an area dotted with lakes in the Danube region. Its original findspot is uncertain, including its proximity to the village of Desa, since that location only marks the middle part of a roughly $20-30 \mathrm{~km}$ long area; the more precise definition of the findspot would be "between Ciuperceni and Ghidiciu". ${ }^{203}$ The Hotărani handle fragment comes from the shore of Lake Balta Mare and it was found in direct association with the Blahniţa Stream, which drained the periodic floodwaters in the oft-inundated floodplain area. ${ }^{204}$ The Boşneagu cauldron was found near the Danubian floodplain, but it came to light when a pit was dug in the yard of a peasant house in the village. The fragment lay at a depth of $1.5 \mathrm{~m}$. Although there are several lakes around the village, it is uncertain whether these are natural formations and their presence, in itself, is insufficient for a direct association with the cauldron. ${ }^{205}$ The Sudiţi cauldron was found on a settlement that lies beside a stream, similarly to most other archaeological sites. ${ }^{206}$

${ }^{196}$ E.g. Attila 2007, 114.

${ }^{197}$ Karger 1922, 30; Karger 1940, 113, as well as RASCHKE 1940, 117-118, quoting the finder's report.

${ }^{198}$ KARGER 1940, 113-114. For the find, see also RASCHKE 1940, Taf. 14, 15/3; TAKács 1955, 147; MAENCHEN-HELFEN 1973, 308; Bóna 1991, 241; TeJRAL 2000, 151 (n.v.); LosKotová 2011, $126-128$.

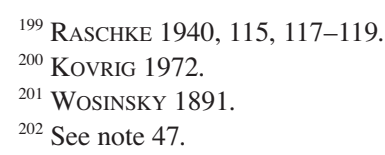

${ }^{203}$ NeSTOR-NicOLAESCU-PLOPŞOR 1937, 178.

${ }^{204}$ NeSTOR-NiCOLAESCU-PlopŞOR 1937, 179.

${ }^{205}$ Mitrea 1961, 550

${ }^{206}$ Mentioned by HarHoIU 1997, 130, 189/84, published in Attila 2007, 333. The find context is uncertain: the cauldron was allegedly found during the excavation of a Bronze Age settlement and was apparently recovered from a smelting furnace. If this was indeed the case, we may assume a late Roman-period or Hun-period settlement where craft activities were pursued. ANKE 1998, 52, too considers this cauldron to be a late Roman settlement find. 


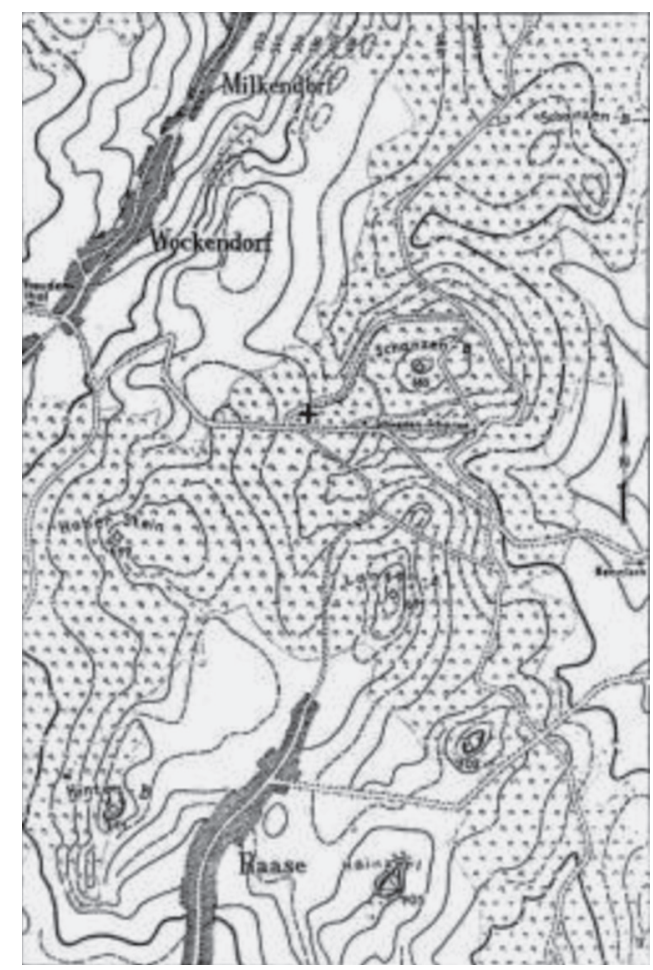

Fig. 23. The secondary findspot of the Razová cauldron fragment (after RASCHKE 1940)

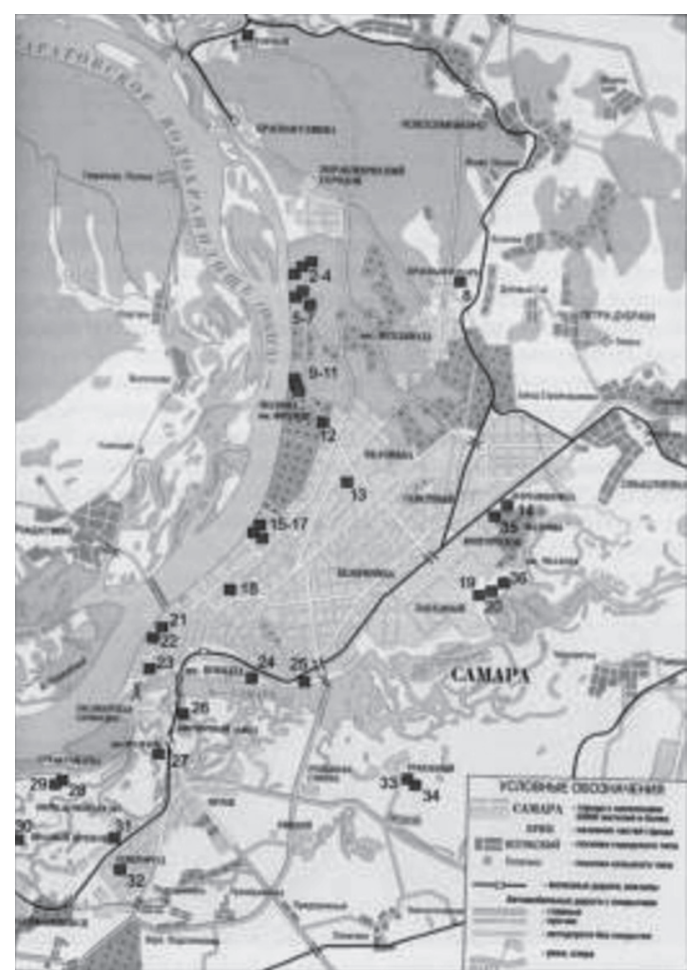

Fig. 24. Findspot of the Samara cauldron fragments (no. 29, after КОчКИНА-СТАШЕНКОВ 2014)

There is detailed information on the find context of the Ioneşti cauldron. It was found at a depth of $6 \mathrm{~m}$ in the groundwater table, some $500 \mathrm{~m}$ from the current channel of the Arges River. Overlying the cauldron was an undisturbed riverine deposit, which could only have accumulated after the cauldron's deposition. It has been suggested that the cauldron had originally been buried at a depth of $1.5 \mathrm{~m}$, which does not exclude a deposition in a river channel. ${ }^{207}$ However, the evidence is not convincing. The $6 \mathrm{~m}$ thick deposit simply reflects the river's mobility and the twentieth-century conditions can only be tentatively compared to the one-time environment. Even so, this is the best, most reliable example that a cauldron's findspot can be directly associated with a river or its floodplain.

The location of the Ivanovka site "near the Don Delta" is uncertain, as are its find circumstances, and the findspot can only be identified tentatively on the basis of the information contained in the archaeological literature. ${ }^{208}$

The Soka cauldron was allegedly found in a dried-up stream channel. Several variations of the site's name and its location have appeared in the archaeological literature. The actual site lies some $100 \mathrm{~km}$ west of the Volga. ${ }^{209}$

The find circumstances of the Verkhniy Konets cauldron are not known. ${ }^{210}$ The findspot of the northernmost Hunnic cauldron known since long has been specified variously. It does not lie in the Volga-Kama catchment in the geographical sense, but beyond it, on the bank of one of the tributaries of the Dvina that flows into the White Sea.

The Khabaz cauldron was an unstratified find from a chamber grave in an extensive cemetery. The site itself lies in a river valley, which is the case for most Caucasian sites. ${ }^{211}$

${ }^{207}$ Harhoiu-Diaconescu 1984, 99, cp. Abb. 1-2.

${ }^{208}$ FETTICH 1940, 248; BÓNA 1991, 240-241; ANKE 1998, Teil 2, 54.

${ }^{209}$ The Soka cauldron, originating from a Russian princely private collection, became known to European archaeological scholarship after its drawing was published by M. Wosinsky, who, however, specified an erroneous findspot (WosINSKY 1891, 430). The drawing itself was mixed up with an illustration of the Verkhniy Konets caul- dron following a mistake made by Hampel. The exact findspot of this cauldron was eventually clarified by Russian scholarship in 1900. For a detailed discussion, see BóNA 1991, Abb. 14, 2; 240); for its photo, see Werner 1956 and MAENCHEN-HeLfen 1973, 316, Fig. 45; БОТАЛОВ 2009, Fig. 58, 127, 156).

${ }^{210}$ The drawing of the cauldron was adopted from M. Wosinsky's study in the archaeological literature (WOSINSKY 1891, 430).

${ }^{211}$ БАТчAEB 1984; BÓNA 1991, 240. 
The Nanshan cauldron was associated with water on the testimony of the patina on the vessel and in keeping with the theory of ritual practices linked to water. ${ }^{212}$ As a matter of fact, the cauldron's find circumstances are wholly unknown. Only so much can be known that the cauldron had been found by a shepherd in 1976 and that his son had presented it to the Ürümqi museum after his death, where Miklós Érdy discovered it in $1989 .{ }^{213}$

The Kapos Valley and Soka cauldrons, which according to the reports were both found in stream valleys, had actually been discovered during ploughing at a shallow depth in the nineteenth century. However, the area of the findspots was not examined in order to determine whether it was suitable for human settlement or whether there were any settlement traces in their proximity.

The best examples for a close association with water are represented by the Wallachian cauldrons (one caught up in a fishnet, another found on a riverbank, etc.) and it is therefore not mere chance that the hypothesis was first proposed by Romanian scholars, which was then adopted by international scholarship and extended to Eurasia. Actually, the first formulation of the theory was more in the nature of a speculative question, ${ }^{214}$ but the rite itself was never explored in detail, nor were possible parallels sought. A look at the Lower Danubian finds reveals that a deposition near water was assumed in the case of each findspot, the only exceptions being the cauldrons found in the Hinova and Sucidava forts. A possible association with water was never suggested in the case of the cauldrons from Celamantia and Intercisa (as well as Olbia), probably because their find contexts appeared to differ substantially, even though this is not the case. A cauldron fished out of the Danube during a flood reveals little about the one-time context, only that its place of deposition lay immediately by the Danubian limes, similarly to the Roman military forts and installations where cauldrons have been found.

Viewed from this perspective, the cauldrons found in the Perevolotchna and Tsimlyansk reservoirs could plausibly be associated with the ritual role of water, even though both findspots lay near strategically important fording places over the Don and the Dnieper. The recent finds discovered on the Pontic littoral (Malai, Buzhor) could also be mentioned, as could the Samara cauldron fragment and the Balatonlelle-Rádpuszta cauldron brought to light on the shore of Lake Balaton, even though in these cases, it was not so much the proximity of water, but rather the settlement and the proximity of communication routes that can be directly linked to the cauldrons. ${ }^{215}$ For example, although the Samara fragment was found directly on the Volga bank, the ninth-century grave goods found nearby indicate that the area was suitable for human settlement (Fig. 24). ${ }^{216}$ Among the more recently discovered cauldrons, only the exemplar from Lichnov was quite certainly found on a stream bank. However, it is also emphasised that the findspot of the cauldron fragment found by metal detectoring is uncertain in the sense of whether the findspot can be regarded as the actual place of deposition or whether the small handle fragment had been carried there by the water secondarily. ${ }^{217}$

Another intriguing question is why only decorated body fragments and handle fragments are found in addition to complete cauldrons. ${ }^{218}$ The answer is fairly obvious and can probably be explained by taphonomy. It is more difficult to recognise a plain copper sheet fragment than a mushroom-shaped handle for what it is - one case in point being the Ócsa fragment found by a metal detectorist. Had the fragment been undecorated, its identification would have been impossible. How does a metal vessel buried in a special location come to light? It is ploughed up, washed ashore, or - very rarely - it is excavated. Thus, the association with water seems quite natural: the overwhelming majority of archaeological sites lies in the proximity of some living water since water is indispensable to human life.

\section{THE ROMAN CONTEXT}

Studies on Hunnic cauldrons tend to treat the finds brought to light in Roman forts separately from the other pieces. The fragments found in Roman forts are generally interpreted as pieces associated with the foederati, eastern population groups under Roman overlordship, and they are therefore assigned an earlier date than the other

\footnotetext{
${ }^{212}$ KоCH 1997, 641-642, 8, note 17.

${ }^{213}$ ÉRDY 1990; ÉRDY 1995, 5-7, 32.

${ }^{214}$ NeStOR-NicOLAESCU-PlopŞOR 1937, 182

215 TOMKA 2005.
}

${ }^{216}$ КОЧКИНА-СТАШЕНКОВ 2014, 46.

${ }^{217}$ LosKotová 2011, 126

${ }^{218}$ BÓNA 1991, 144. It has also been suggested that a ritual role can be ascribed to the separate deposition of cauldron handles. 
cauldrons; ${ }^{219}$ it is also assumed that they had perhaps served as raw material for the forts' occupants. ${ }^{220}$ Topographic surveys and control excavations have rarely been conducted in the case of the stray pieces not originating from Roman forts, and little attention has been paid to topographic work in their cases. Still, their association with contemporaneous sites has been suggested and the links with the antique world can also be broadened in the light of the new material. In order to examine the relationship between the cauldrons and late Roman topography, we must first identify the finds that can be associated with antique forts or towns, or with Roman or barbarian rural settlements, as well as the stray finds in whose case an association of this type is not known.

\section{A review of the sites}

The cauldron fragments from Celamantia, Intercisa, Hinova and Sucidava come from Roman forts. ${ }^{221}$ It is rarely noted that with the exception of the Intercisa fragment, the other twelve pieces were found on the left Danube bank, from Roman installations erected on barbarian territory. Among the cauldrons from the Lower Danube region, the stray finds from Hotărani, Desa and Boşneagu can be likened to these pieces in the sense that they were all found on the fringes of the Danubian floodplain. ${ }^{222}$

The find context of the Olbia cauldron fragment is unknown. The function of the fragment, which reached the museum in 1902 from a local antiquities dealer, was only recognised in 1994. Although its findspot was specified as Olbia, this cannot be regarded as a wholly reliable piece of information, even though it would have been rather pointless to falsify the findspot of an artefact of (then) unknown function. ${ }^{223}$ Still, even assuming that this had been the case and that the fragment was not found in the town, it most likely originates from the town's territorium and some significance can be attached to this on the imperial level. Similarly to the entire region, the town was devastated in the 230s, and its significance also declined in the fourth century. According to recent research, its trade did not cease entirely and a continuous urban life can be demonstrated up to the last third of the fourth century. ${ }^{224}$

The Simferopol cauldron fragment from Neapolis Scythica, the capital of the Crimean Scythians, was allegedly found in a third-century pit in the town's south-eastern part. ${ }^{225}$ The town was continuously occupied during the Roman period; its abandonment can be dated to the fourth century. ${ }^{226}$

The findspot of the Buzhor fragments, found by metal detectoring, ${ }^{227}$ lies a few kilometres from Anapa, antique Gorgippia. The town of Gorgippia was one of the major centres of the Roman-period Bosporan Kingdom, where urban life is attested up to the fourth century. ${ }^{228}$ Other Hun-period finds have also been reported from the town. ${ }^{229}$

A Roman-period barbarian settlement of the Przeworsk culture was identified in 1988 near the findspot of the Jędrzychowice cauldron. ${ }^{230}$ The Rádpuszta cauldron as well as the Sudiţi and Tymkove cauldron fragments came to light during settlement excavations. Although the material brought to light on the Cherniakhov settlement has not been published in full, we know that the Tymkove fragment was recovered from a $2 \mathrm{~m}$ deep storage pit with a mouth diameter of $1.3 \mathrm{~m} .{ }^{231}$ This context is best paralleled by that of the Rádpuszta cauldron.

${ }^{219}$ Most recently by TEJRAL 2011, 346-351.

${ }^{220}$ Most recently by RAJTÁR-ZÁBOJNíK 2010, 120-121.

${ }^{221}$ HARHOIU-DiACONESCU 1984, Abb. 6; BÓNA 1991, 144-145.

${ }^{222}$ As highlighted by Mitrea 1961, 554.

${ }^{223}$ РЕДІНА-РОСОХАЦЬКИЙ 1994, 152, illustration: ibid., Fig. 1, 4; ANKe 1998, Taf. 33, 5.

${ }^{224}$ КРыЖИЦКИЙ-РуСяЕВА-ЧЕРнЕНко et al. 1986, $377-$ 378; KRAPIVINA 2010, 73.

${ }^{225}$ АчкинАзи 1987 (n. v.); ANKE 1998, II. 115; Taf. 35, 5.

AJBABIN 2011, 68, speaks of a humus layer overlying the ruins.

226 ЗАЙЦЕВ 2003, 45-46.

${ }^{227}$ Новичихин 2014.

${ }^{228}$ KHATCHATOUROVA 2001, 264-265.

${ }^{229}$ Новичихин 2014, 169.

${ }^{230}$ LOPUSIEWICZ-ZMUDZINSKI 1991. The relationship between the cauldron and settlement remains uncertain. The late Roman settlement layer uncovered in the sounding did not indicate an intensive occupation. In contrast, the settlement lying some 400-500 m from the Hun-period burial at Jakuszowice, investigated as part of a research excavation, was an intensively occupied settlement of the Przeworsk culture with a long use-life, where traces indicating the working of iron and bronze as well as of precious metals and amber were found. A pottery kiln was also uncovered. The settlement was interpreted as an administrative and economic centre which, on the testimony of the small finds, retained its importance during the Hun period too (for comprehensive overviews, see GoDŁOWSKI 1995, 157-161; KACZANOWSKI-RoDZIŃSKA-NowAK 2008, and LosKOTOVÁ 2011, 128).

${ }^{231}$ The pit also yielded a bone plaque with zoomorphic decoration and a few animal bones: РЕДІНА-РОсОхАЦьКИЙ 1994, 152-153; Abb 1/1. The site was earlier published under its Russian name as Timkovo. 
The relation of the other stray cauldron finds to micro-regional topography is controversial. As far as I know, the Ócsa fragment is the single find in whose case the broader area of the findspot was surveyed using modern techniques and thus the fragment can be tentatively associated with a late Sarmatian settlement. The Şestaci cauldron was ploughed up from a depth of $0.8 \mathrm{~m}$. Although hand-thrown pottery fragments were found beside it, the nature of the site remains controversial. ${ }^{232}$

The significance of a few findspots can be understood in a broader regional context. It has been repeatedly pointed out that the Benešov and Jędrzychowice cauldrons came to light in a strategically important region. ${ }^{233}$ The area of the Benešov cauldron was inspected in spring and autumn 1919, but no "culture layer" (Kulturschicht) was found. ${ }^{234}$ Together with the recently found Lichnov fragment, the three finds reflect the outstanding importance of the Moravian Gates. A similar interpretation can be offered for the cauldrons from Şestaci and Tymkove found near the Dniester, the Prevolotchna cauldron found on the Dnieper bank, the pieces found in the Volgograd area and, provisionally the exemplars from the Volga region. These either lie near major fording places or the location of the findspots (e.g. on both sides of the Dniester) reflect their prominent role.

As far as I know, the nature of the settlement possibly associated with the cemetery has not been examined in the case of cauldrons recovered from burials (Malai, Khabaz, Nasyr-Kort, Kyzyl-Adyr). However, given that three of the four graves were prominent male burials with weapons, it seems likely that the Khabaz cauldron in the northern Caucasus had been deposited in a similarly rich grave, especially in the light of the stray finds. The Mediterranean imports in this cemetery suggest a former road of regional importance nearby. ${ }^{235}$

In sum, we may say that the strategically important locations are not restricted to the Roman forts since a number of cauldrons were found in similarly significant locations on barbarian territory. Cauldrons have been found not only in Roman forts and in antique towns and their immediate vicinity; a direct relation with a Roman provincial settlement (Balatonlelle), Sarmatian (Ócsa) and Carpic (Sudiţi) settlements as well as settlements of the Przeworsk (Jędrzychowice) and Cherniakhov (Tymkove) cultures have been suggested. This, in turn, bolsters arguments that the Hunnic Empire had made good use of the Roman infrastructure not only in Pannonia, but also in the barbarian territories. ${ }^{236}$

\section{THE ASSOCIATION WITH HUNNIC POWER CENTRES}

The distribution of cauldrons in the Lower Danube region and the Carpathian Basin is expressly linked to the Hunnic power bases, which also influences how they are dated. In general, it is assumed that the Hungarian cauldrons are later and date from the decades when the seat of the Hunnic Empire was relocated to the Carpathian Basin from the Lower Danube. ${ }^{237}$ As we have seen, the typology of the finds does not wholly support this conjecture.

A closer look at the distribution of Wallachian finds reveals that they do not outline one or more power bases on the Oltenian Plain, but are principally found along the limes. The findspots of two pieces (Ioneşti, Sudiţi) lie farther, although not on the plainland, but at the foot of the Carpathians. ${ }^{238}$ The reconstructions of the Hun-period

\footnotetext{
${ }^{232}$ НУДЕЛЬМАН 1967, 306.

${ }^{233}$ First noted by RASCHKE 1940, 119; more recently discussed by LOSKOTOVÁ 2011, 126-128, and TEJRAL 2011, 351.

${ }^{234}$ KARGER 1940, 113-114. Georg Raschke again visited and inspected the site in December 1940 (RASCHKE 1940, 117).

${ }^{235}$ KAZANSKI-MASTYKOVA 2007, 194.

${ }^{236}$ TOMKA 2008, 97 . This issue is obviously closely related to the dating of the end of the Central European barbarian cultures. Although not discussed at greater length here, it must nonetheless be noted that the upper boundary of the final phase of the Przeworsk culture in Upper Silesia, one of the best researched regions, is now believed to have extended into the Hun period, which is also supported by dendrochronological dates (GoDLOWSKI 1995, 162; LosKotová 2011, 128).
}

237 "stimmt die Verbreitung der Kessel auffallend mit den Etappen und Schwerpunkten des Vordringens der Hunnen überein" and "Produkte hunnischer Werkstätten, die nach 425 nach Ungarn verlegt wurden": BÓNA 1991, 145, a view shared by MITREA 1961, 554-555; Kovrig 1972, 117-118; HaRHoIU-DiaconesCu 1984, 110; Kovrig 1985, 143; ZASECKAJA-BOKOVENKO 1994, 710-711; ЗАСЕЦКАЯ 1994, 108; HARHOIU 1997, 134. I. Bóna had earlier believed that the empire's seat had been relocated to the Carpathian Basin directly from the Volga region; later, he modified his view and interpolated a Wallachian centre (BÓNA 1979, 301; BÓNA 1986, 136; BÓNA 1991, 54, 61, 141).

${ }^{238}$ The inclusion of another mushroom-shaped handle fragment housed in the Bucharest museum in the central region of Wallachia on distribution maps leads to a distorted picture because the fragment probably originates from a site in western Lesser Wallachia (NestoR-Nicolaescu-Plopşor 1937, 179). 


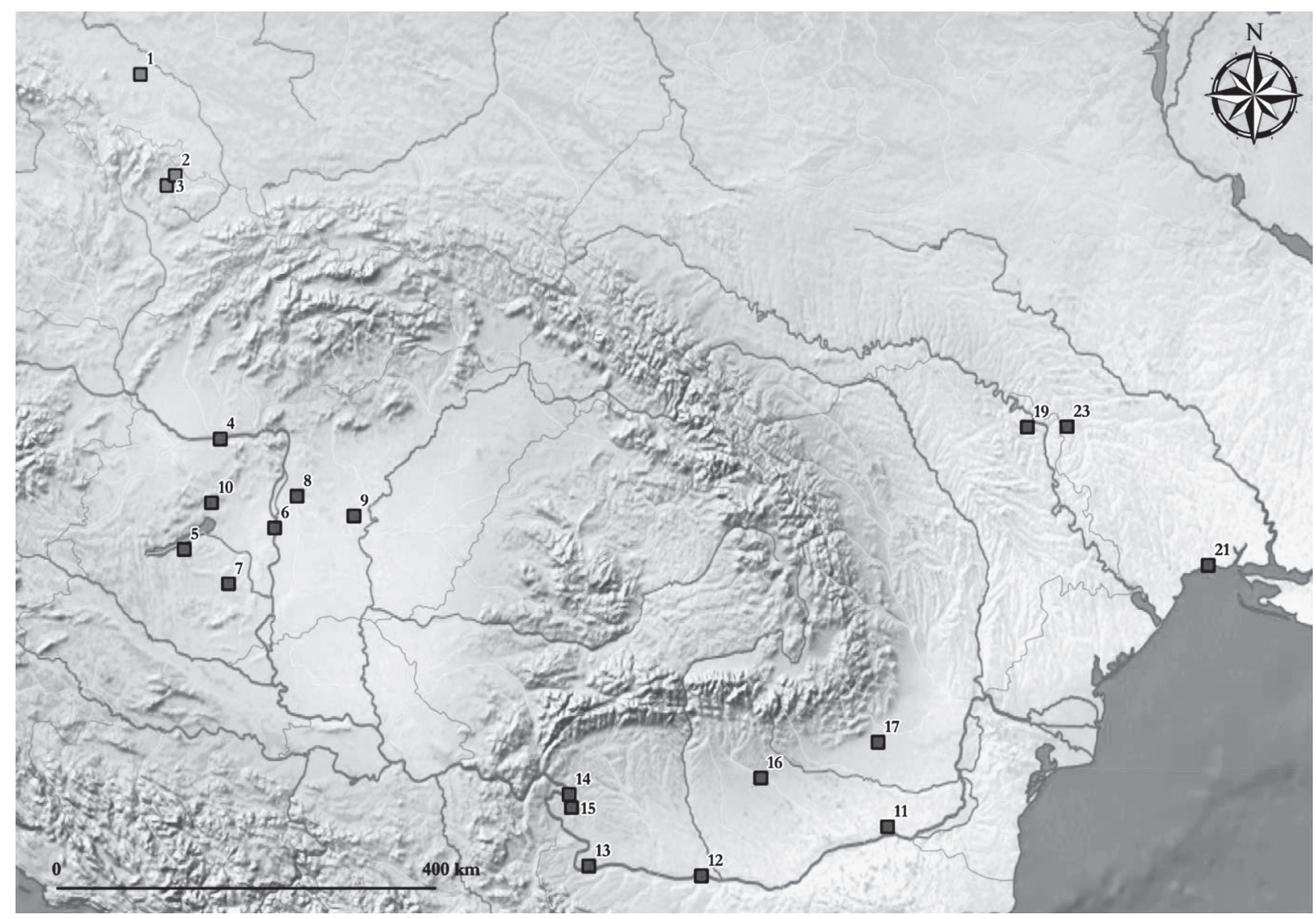

Fig. 25. The western boundary of the distribution of Hun-period cauldrons in Central and Eastern Europe (the numbering of the sites follows that of the Catalogue; map: Zsófia Masek)

power bases would suggest that the distribution of cauldrons does not coincide with the distribution of the major Hun-period finds in Wallachia. ${ }^{239}$

The problems arising from dating the finds in themselves are illustrated by the fact that Romanian scholarship had earlier interpreted these finds as the relics of the Huns retreating eastward after the fall of their empire in the fifth century on the basis of the parallels with the more developed forms in the west, in Hungary. ${ }^{240}$ The cauldrons from Sucidava ${ }^{241}$ and Hinova ${ }^{242}$ are generally cited when dating these finds, which are usually assigned to around 400/410. ${ }^{243}$ However, similarly to the Hungarian finds, it could be argued that they are in fact dated on historical grounds since the end of the forts' occupation is uncertain. ${ }^{244}$ The Sucidava fragments were found in different parts of the fort, but their exact stratigraphic contexts are unknown. One was found near a hoard of bronze coins whose latest piece is an issue of Theodosius II, which cannot be dated more closely. ${ }^{245}$ The initial report does not restrict the end of the fort's occupation to the earlier fifth century (more precisely, of the late Roman fort, before its Byzantine renewal), a dating that is still acceptable today. ${ }^{246}$ The coin circulation of the Hinova fort shows a similar pattern.

${ }^{239}$ CIUPERCĂ-MĂGUREANU 2008, 125, Fig. 3; КАЗАНСКИЙ 2014, 328-329, Fig. 26. The single exception is the cauldron fragment from Sudiţi, whose findspot lies on the assumed territory of the power base in the Buzău region, a few kilometres away from two burials yielding diadems (Gherăseni, Buhăieşti) and from Pietroasele (Ciobanu-Constantinescu 2008, Abb. 3 and 136).

${ }^{240}$ NeSTOR-NicOLAESCU-PlOPŞOR 1937, 182. Later, a date between 375 and 454 was also proposed (MitrEA 1961, 554), and the possibility of a late date was also noted by ANKE 1998, 54.
${ }^{241}$ TUdoR 1941, 375, Fig. 10, c; TUdOR 1948, 187-188, 189, Fig. 35, 1-2, 7.

${ }^{242}$ DaVidescu 1980, 83; 84, Fig. 7.

${ }^{243}$ GomolKa-Fuchs 2007, 215; TeJRal 2011, 347-348.

${ }^{244}$ HARHOIU-Diaconescu 1984, 109-110; ANKE 1998, 53, note 307. This is accepted, e.g., by TEJRAL 2010, 108.

${ }^{245}$ Tudor 1948, 187, 198-200. The hoard was made up of 889 coins.

246 TUdOR 1948, 205-206; RAJTÁR-ZÁBOJNÍK 2010, 120. Cp. Harhoiv 1997, 133-134. 
The cauldron is associated with the fort's first destruction, which rather suggests a date before the reign of Theodosius II. ${ }^{247}$ Obviously, the Hinova fragment can hardly be used for dating all the Wallachian cauldrons. ${ }^{248}$

It must also be borne in mind that in contrast to Pannonia, the imperial border in Moesia had retained its importance during the Hun period too. The Roman limes meant that the region also acted as the border of the Hunnic Empire that had to be defended and it is also possible that army troops were assembled in this region before launching the Balkanic campaigns. ${ }^{249}$

We have no reason to doubt that the central seat of the Hunnic Empire was located in the central region of the Hungarian Plain in the 440s as reported in the written sources. ${ }^{250}$ How, then, can we explain that the greater part of the cauldron finds from the Carpathian Basin do not originate from the heartland of Attila's empire? The Hunnic cauldrons and the locations of the so-called funerary sacrifices (as the relics of ritual activities of eastern origin quite certainly practiced in the Hun period) outline a smaller area in the Carpathian Basin, which coincides with eastern Pannonia and Valeria, with a smaller part falling into Pannonia Prima and the Hungarian Plain. ${ }^{251}$ One reasonable question is whether this distribution can be compared to the distribution of the Wallachian pieces. In order to do so, we must first examine whether it is possible that the Hungarian cauldrons mark the border of the Hunnic Empire similarly as in the Lower Danube region (Fig. 25).

It has been repeatedly emphasised in Pannonia studies that Valeria was open towards the west and it remains uncertain whether the province had clearly defined borders. Thus, the western border of the Hunnic Empire during the last decades of its existence did not necessarily coincide with the administrative border of Valeria Ripensis. ${ }^{252}$ Endre Tóth came to a similar conclusion from his study of the distribution of Roman gold solidi. ${ }^{253}$ Another long-standing line of reasoning in Pannonia studies regarding Roman continuity is that the survival of geographic names can only be demonstrated in western Transdanubia and south of the Drava, and that this can be seen as the legacy of the Hun period. ${ }^{254}$ The territory on which this continuity cannot be noted ${ }^{255}$ more or less coincides with the Pannonian boundary of the distribution of cauldrons. Obviously, it is impossible to draw well-defined boundaries on the maps, as best exemplified by the sacrificial assemblage found at Pécsüszög, which lies immediately by Sopianae, a town in which the survival of the built heritage and the presence of a Christian community can be assumed in the first decades of the fifth century, and whose early medieval continuity is reflected in geographic names and material culture alike.

Despite these uncertainties, it is striking that, looking at the most recent reconstruction of the late Roman division of the province, each Pannonian cauldron was found in Valeria (Fig. 26) ${ }^{256}$ Viewed from a (Hunnic) imperial perspective, we can draw a parallel between the distribution of cauldrons in the Carpathian Basin and the Lower Danube region. The two distribution territories suggest that the finds are not reflections of the westward shifting power bases, but rather of the borders and extent of the Hunnic Empire. ${ }^{257}$

The interpretation of the Pontic sites (Olbia Pontica, Simferopol/Neapolis Scythica, Buzhor/Gorgippia) has a similar duality to it. From an imperial perspective, they can be associated with antique centres and locations representing the highest level of the settlement hierarchy and communication channels, and - additionally - this region acted as an imperial border until the Huns maintained their control over it. ${ }^{258}$ The same holds true for the

\footnotetext{
${ }^{247}$ DAVIDESCU 1980, 82-83.

${ }^{248}$ A view shared by TeJRAL 2010, 108, and TeJRAL 2011, 348-349, according to whom the cauldrons found in Pannonian forts could even be dated earlier than the pieces found in non-Roman contexts in the province's interior.

${ }^{249} \mathrm{Cp}$. the Hunnic campaigns against the East Roman Empire: BuRY 1923, 271-276; VÁCZY 1940, 89-91; NAGY 1956; ALtHEIM 1962, 186-187, 271-272, 291-293, 310; Mócsy 1974, 351-352; VÁrady 1978, 104; Demougeot 1979, 389-393; Pohl 2007, and BÓNA 1984, 269-273, bearing in mind that the Danube still marked the empire's border after the Peace of Anatolius concluded in 450.

${ }^{250}$ Priscus fr. 11-14. ThOMPSON 1948, 102-120; for the new edition, see Heather 1996, 240-242.

${ }^{251}$ BÓNA 1991 Abb. 69 (Kartenbeilage).

${ }^{252}$ SZÁsz 1943, 155; MAENCHEN-HELFEN 1973, 64-66,
} 87-89; То́тн 2009, 175 .

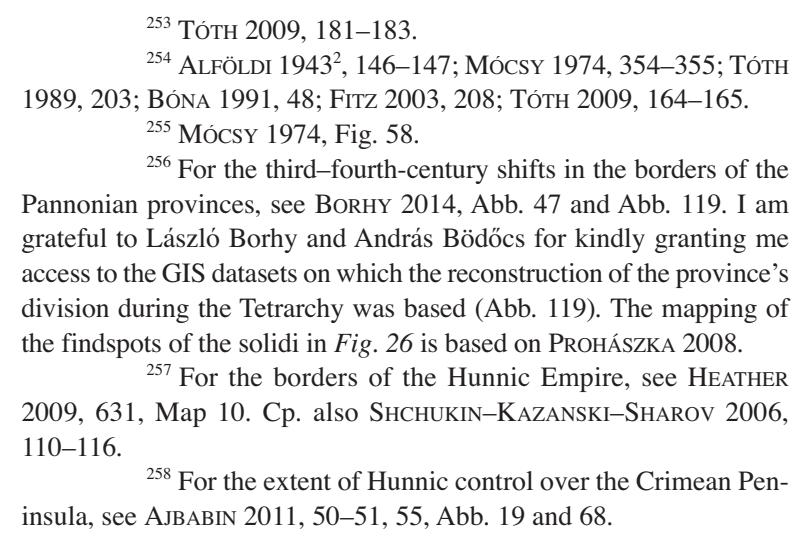

${ }^{254}$ ALFÖLDI 19432 , 146-147; MóCSY 1974, 354-355; TóTH 1989, 203; BóNA 1991, 48; FITZ 2003, 208; То́тH 2009, 164-165.

${ }^{256}$ For the third-fourth-century shifts in the borders of the Pannonian provinces, see BoRHY 2014, Abb. 47 and Abb. 119. I am grateful to László Borhy and András Bödőcs for kindly granting me access to the GIS datasets on which the reconstruction of the province's division during the Tetrarchy was based (Abb. 119). The mapping of the findspots of the solidi in Fig. 26 is based on ProHászKa 2008.

${ }^{257}$ For the borders of the Hunnic Empire, see HEATHER 2009, 631, Map 10. Cp. also Shchukin-KaZAnSKi-Sharov 2006, $110-116$

${ }^{258}$ For the extent of Hunnic control over the Crimean Peninsula, see AJBABIN 2011, 50-51, 55, Abb. 19 and 68. 


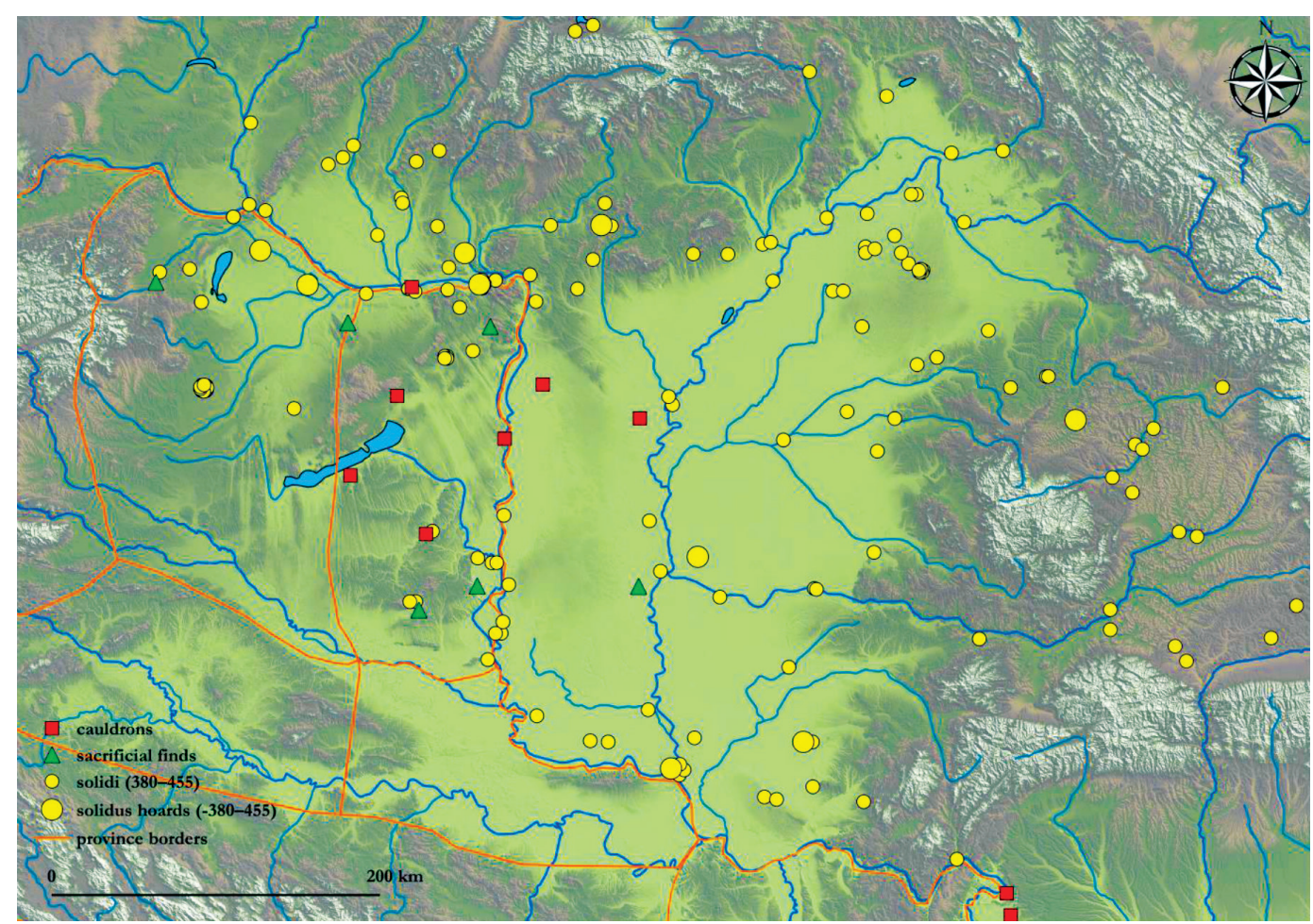

Fig. 26. Distribution of Hun-period cauldrons, sacrificial finds and gold solidi in relation to the borders of Pannonia (the solidi found in Pannonia Secunda and Savia are not shown; map: Zsófia Masek)

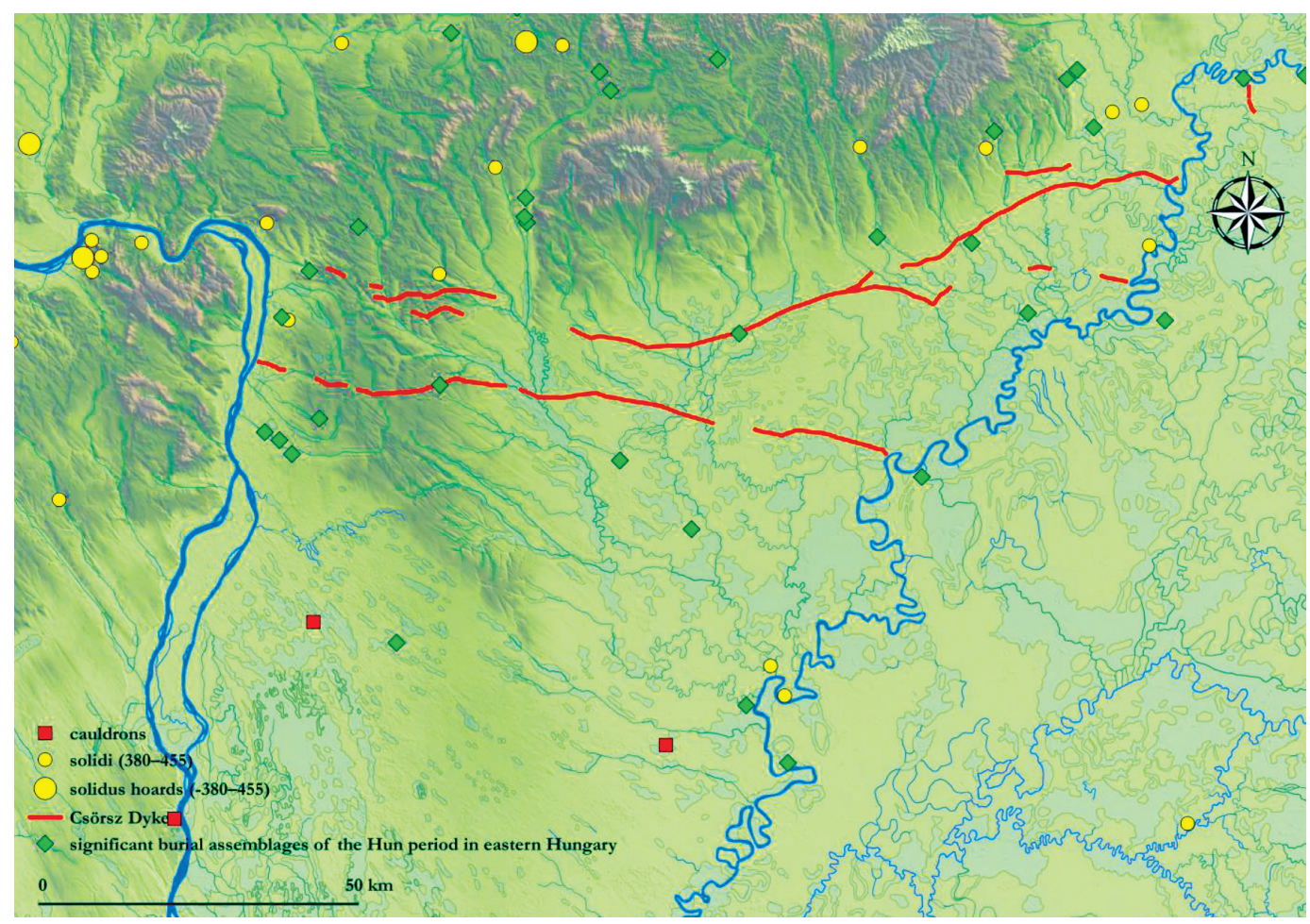

Fig. 27. Relation between the Hunnic cauldrons and the Hun-period burials in the northern half of the Danube-Tisza interfluve (the finds and burials south of Intercisa and the Körös Rivers are not shown; map: Zsófia Masek) 
northern Caucasus (Khabaz, Nasyr-Kort). ${ }^{259}$ The Malai burial in the Kuban region, which can probably be dated well after the fall of the Hunnic Empire, cannot be fitted into this interpretative framework.

The interpretation of the other Eastern European and even more easterly burials is by necessity more problematic. These could be easily transformed from border regions into central areas as the empire expanded, and they were either no longer border regions during the empire's greatest extent, or the issue cannot be resolved, as, for example, in the case of the three cauldron finds from the Czech Republic and Poland, which could mark the western boundary of the territory under direct Hunnic authority, but they could equally well indicate control over the route to the Baltic. What seems certain is that this region, the southerly part of Upper Silesia, coincided with the southern fringes of the Przeworsk distribution. ${ }^{260}$

The cauldrons from the Hungarian Plain (Törtel, Ócsa) were found in a region that is strikingly poor in Hun-period finds. The area of the Ócsa findspot probably enjoyed a prominent status in regional infrastructure. The significance of the broader area lying opposite Aquincum has already been noted in Hungarian scholarship, ${ }^{261}$ which is also supported by the distribution of the few Hun-period sites (Fig. 27). The reconstruction of the Roman-period roads across the Hungarian Plain does not include a direct Aquincum-Parthiscum route. ${ }^{262}$ As we have seen, a possible association between the Törtel site and the Aquincum-Porolissum road is uncertain. The role of the two sites on the Hungarian Plain can broadly be explained by the area's inter-regional role. On the micro-regional level, however, this remains uncertain. What can most certainly be excluded in the light of the present record is that the two cauldron finds can be linked to a Hun-period power base.

The findspots of the cauldrons found on both banks of the Dniester (Şestaci, Tymkove) in the eastern foreland of the Carpathians lie strikingly close to each other. ${ }^{263}$ In the light of the current evidence, the two sites lie in an area rich in Hun-period finds (the so-called Bukovina power base) or, more precisely, on its eastern fringes. ${ }^{264}$ The same holds true of the Sudiţi fragments among the Romanian cauldrons (the power base in the Buzău region). ${ }^{265}$ The location of their findspot in the micro-region can thus be likened to the Högyész cauldron found near Regöly and Murga (see above). In the case of the Perevolotchna site, it has been emphasised that the grave assemblage found on the other side of the Vorskla mouth, published together with the cauldron, quite obviously reflects the prominent role of the fording place in the Hun period. ${ }^{266}$ It was later suggested, in line with the assessment of other assemblages from the Dnieper region, that these finds can be seen as the relics of the re-settlement of the Alans during the Hun period. ${ }^{267}$ The Hunnic cauldrons of the forested steppe region are traditionally regarded as a clear indication of Hunnic overlordship, ${ }^{268}$ in other words, the archaeological finds outline territories and borders about which we would hardly know without these finds.

The relics from Eastern Europe make it unlikely that all the finds can be interpreted as markers of border territories. Also, the smaller power bases and the empire's border territories could have coincided (e.g. in southern Pannonia) and do not necessarily exclude each other. A more nuanced picture can only be drawn in the regions lying closer to the Roman Empire, in part based on the known historic events and in part owing to our better knowledge of the topography of the antique world. Even so, the earlier "imperial power base" model is unsuitable for explaining the tendencies noted in the Middle and Lower Danube region.

This new model accords primacy to the overall distribution of the finds rather than to their strict dating. This approach is to some extent justified by the empire's rapid expansion and its brief duration, and by the fact that the successive phases of the westward expansion are not necessarily reflected in the archaeological record. At the same time, the typological analyses indicate not only an east to west, but also a strong west to east cultural interaction, making a single-trajectory development highly unlikely. These problems can be circumvented by assuming that the specialised craftsmen producing the cauldrons retained their cultural contacts from the Danube region to

\footnotetext{
${ }^{259}$ For the Caucasian campaigns of the Huns, see THOMPSON 1948, 26-31; Altheim 1962, 317-319; Maenchen-Helfen 1973, 51-59; DeMougeot 1979, 387-389.

${ }^{260}$ Loskotová 2011, 128.

${ }^{261}$ E.g. LÁSZLÓ 1942, 781-784; NAGY 1975, 186-188.

${ }^{262}$ E.g. Gabler-Vaday 1986, Abb. 21; Gabler-Vaday 1992, Abb. 1; VADAY 2003, Fig. 26.

${ }^{263}$ РЕДІНА-РОСОХАЦЬКИЙ 1994, 154, too highlighted that the distance between the two sites is no more than $40 \mathrm{~km}$ and that the
}

Tymkove fragment bears a high resemblance to the Şestaci cauldron, their nearest counterpart being the piece from Desa (НудельмАН 1967, 307).

${ }^{264}$ Popa 2007, 170; Harhoiu 2007, 92; CiupercăMăguREAnU 2008, Fig. 3.

${ }^{265}$ Ciobanu-Constantinescu 2008, Abb. 3.

266 ЛЕвченко-СУПрУНенко 1994, 75, ris. 29 and 80.

${ }^{267}$ KAZANSKI-MASTYKOVA 2000.

${ }^{268}$ E.g. VÁCZY 1940, 84; BóNA 1991, 40. 
the Caucasus region until the fall of the empire, even if it is quite obvious that cauldrons were used over a longer time in this region (Nasyr-Kort, Malai).

\section{THE POWER BASE ON THE HUNGARIAN PLAIN AND THE CHRONOLOGY OF THE HUN-PERIOD ARCHAEOLOGICAL MATERIAL IN PANNONIA}

The dating of the Hungarian cauldrons changed simultaneously with the alterations in the historical narrative accepted in the period's scholarship. The two principal issues are the dates of when the empire's seat was relocated to the Hungarian Plain and when the Huns gained control over Pannonia.

According to the most widely accepted narrative, the power base on the Hungarian Plain was established in the 420s and the Huns occupied Pannonia in the 430s. The foundations of this view were set down quite some time ago in the period's research. ${ }^{269}$ Although the date of 433 has been challenged on both historical and archaeological grounds ${ }^{270}$ a large-scale population change from the 420 s or after 433 in Valeria ${ }^{271}$ (or in Valeria and Pannonia Secunda ${ }^{272}$ ) is still current in Roman as well as in Migration period studies, despite the fact that the surrender of the provinces as part of a treaty remains uncertain. ${ }^{273}$ Endre Tóth has aptly noted that the determination of when Valeria was handed over to the Huns is a "near-impossible task" and that the date should be crossed out from among the major turning-points of Pannonian history. ${ }^{274}$

In terms of historical chronology, we can, at best, specify the date of the final abandonment of the Danubian limes as having occurred sometime in the $430 \mathrm{~s} .{ }^{275}$ Even so, neither the ceding of Valeria by contract, nor the creation of Valeria Media can in itself justify the narrow periodisation of the archaeological material to before and after the 420s-430s, and neither can a historical narrative along the same lines automatically imply the cessation of Roman life in Valeria, ${ }^{276}$ or the end of the use of the late Roman cemeteries, ${ }^{277}$ or, for that matter, the narrow date range of Group 2 of smoothed-in pottery. ${ }^{278}$ The point is repeatedly raised that the archaeological material should be treated on its own terms and differentiated without recourse to the historical sources in order to avoid the pitfalls of a mixed argumentation. ${ }^{279}$

The problem does not simply lie in drawing the boundaries of a relative and absolute chronology. The real issue is whether the archaeological material is suitable for determining chronological boundaries of this type. Cauldrons can be seen as a good case, illustrating the point that this issue cannot be methodologically resolved if the artefacts in question are stray finds (as most cauldrons are), if their find contexts are uncertain (Intercisa) or if they defy a finer chronological resolution (Balatonlelle). Given the nature of the source material, neither can it be determined whether there is an association between the use and deposition of cauldrons and the systemic presence of provincial Roman culture (the limes, the existence of urban life, the continuity of the infrastructure, the use of late Roman cemeteries, etc.), ${ }^{280}$ explaining the simultaneous recourse to two interpretative frameworks: the first, according to which cauldrons can be seen as the relics of the foederati who were allies of the Roman Empire, the second, which dates cauldrons to after the collapse of the limes. ${ }^{281}$ As we have seen, typological studies are in themselves unsuitable for resolving this issue.

${ }^{269}$ Bury 1923, 271-272; MAenchen-Helfen 1973, 76-90; MócsY-Fitz 1990, 50-51; То́тн 2009, 172-178. For the proposed earlier dates of 406 and 409, see ibid. 173-174, and ALFÖLDI 1926, 71; ALFÖLDI 1942, 728-729; for an earlier critique, see Mócsy 1962, 581-582.

${ }^{270}$ KonRAD-Witschel 2011, 15-16; BierbRAUER 2011, 132. For the ample literature on this issue, see Tótн 2009, notes 1053-1055.

271 Tо́тн 2009, 165, 189; VIDA 2011, 626, 637.

${ }^{272}$ E.g. ŠAŠEL $1979,128$.

273 Tóth 2009, 172-176.

${ }^{274}$ Tо́тн 2009, 176.

${ }^{275}$ MóCSy 1974, 339-351; Soproni 1985, 105-106; FITZ 2003, 208. Cp. VÁRADY 1969, for the survival of the Pannonian limes (esp. 346-348), and its critique by, e.g., Mócsy 1971b, 357-358.
${ }^{276}$ BÓNA 1984, 269; BÓNA 1991, 48-49.

277 Tо́тH 2009, 189.

278 TÓTH 2009, 180-181.

${ }^{279}$ HeINRICH-TAMÁSKA-ProháSZKA 2008， 151; BIERBRAUER 2011, 137.

${ }^{280}$ Meaning that they are more typical for the D1 period or, rather, of the D2 period, within their original relative cultural context: see TEJRAL 1988, 267-295.

${ }^{281}$ For a detailed discussion, see, e.g., KovRIG 1972, 118120. ANKE 1998, 52-54, argued for an association with the foederati, while not excluding the possibility of a later date; for similar arguments, see, e.g., RAJTÁR-ZÁBOJNíK 2010, 122. TEJRAL 2010, 108-109; TEJRAL 2011, 346-349, opts for an early date; in contrast, BóNA 1991, 145 , wholly excludes the possibility of an early date. 
Thus, there is an ongoing debate about the last decades of Pannonia in archaeological and historical scholarship. This is to some extent, although less notably, also reflected in the research of the Hungarian Plain. The belief that the seat of the Hunnic Empire was relocated to the Hungarian Plain in the mid-420s (sometimes specified as 424,425 or 423-425) has dominated Hunnic studies for the past decades, principally in the wake of I. Bóna's work. ${ }^{282}$ However, this is not the single credible narrative of historical events. An alternative narrative is current in international scholarship, which fits in more with the earlier view that has Pannonia evacuated and surrendered at an early date, in 409 - although it represents a relevant scenario on its own merit, without this strand. ${ }^{283}$

A closer look at Bóna's reasoning reveals that he had probably based his narrative on János Harmatta's work. ${ }^{284}$ However, Harmatta had been much more circumspect than Bóna: in addition to highlighting the uncertainties, he dated the relocation of the Hunnic power base to the mid-420s at the earliest. ${ }^{285}$ Previously, in accordance with A. Alföldi's assumption about the early evacuation of Pannonia, Hungarian scholarship had opted for an earlier, early fifth-century date, and had emphasised that the occupation of the entire Hungarian Plain had been a long process, lasting several decades. ${ }^{286}$ This was reflected in András Mócsy's arguments that Hunnic control over Pannonia can be assumed from the 410s and that the foedus of 433 merely formalised an already existing state of affairs. ${ }^{287}$ These more subtly nuanced views have virtually disappeared from Hungarian scholarship since the 1980s and even Pannonia studies quote solely Bóna's works when referring to the Hunnic presence and activity on the Hungarian Plain. ${ }^{288}$ M. Párducz had challenged Bóna's views until 1974, because his contention was that the exact date of when the Huns assumed control could not be precisely determined. ${ }^{289}$

The cornerstone of Bóna's narrative, namely that the power base was relocated in 424/425, was based on the Hunnic contingent sent to support Aetius. The assumption that Valeria was handed over to Ruga in 424-425 in exchange for his military assistance played a prominent role in the reconstruction of the events on the Hungarian Plain. ${ }^{290}$ This supposition, first raised much earlier, was criticised by O. Maenchen-Helfen and Sándor Soproni too considered it no more than a simple conjecture. ${ }^{291}$ By this time, however, the date of 425 had become a conceptual peg for I. Bóna on which he hung the assessment of the Pannonian finds, among others the history of Intercisa, and which essentially determined studies on the fifth-century archaeological material of the Hungarian Plain. ${ }^{292}$ This was one of the main reasons that he dated the Hunnic cauldrons expressly after 425 and only on these grounds could he date the Soka cauldron, one of the northernmost exemplars, to after 425 . $^{293}$ That the date of $425-430$ marked a turning point in the history of Pannonia was challenged from a "western frame of reference" by P. Tomka: "Bóna sieht die Dinge vom Standpunkt eines Valerianers." 294

In the light of the current stand of research on Pannonian events, we may contend that the date of the Hunnic occupation of the Hungarian Plain is as uncertain as that of Valeria, the only difference being that it merely

282 BÓNA 1971, 267-268; BónA 1984, 267-269; BóNA 1986, 136; BÓNA 1988, 117; BÓNA 1991, 157; 212.

${ }^{283}$ Menghin 2007, 36 (405/406); HeAther 2009, 218-222 and 629, Map 8 (“c. 410 ?"). Other scholars have not taken a definite stand, e.g. VÁRADY 1969, 264-266; KoVRIG 1972, 118, notes 60-62; WOLFRAM 1979, 311-317; SOPRONI 1985, 105.

${ }^{284}$ Even though he does not explicitly quote Harmatta. Tо́тн 2009, 174 apparently reached the same conclusion.

${ }^{285}$ HARMATTA 1953, 8-9 (in Hungarian), and 107-108 (in French). Bóna too subscribed to this view (BónA 1965, 116: after 420, BÓNA 1971, 267-268: around 420), although in a study published in 1968, he dated the Hunnic control over the Hungarian Plain to 410, which can be seen as the influence of the earlier historical narrative advocated by A. Alföldi (BóNA 1968, 102).

${ }^{286}$ ALFÖLDI 1934², 42-43; VÁCZY 1940, 75-81.

${ }^{287}$ Mócsy 1971, 351-352, Mócsy 1974, 358. A similar view was put forward by THOMPSON 1948, 32, 62-63, who accepted the foedus of 433 , but nonetheless suggested that a Hunnic presence in Pannonia - and thus on the Hungarian Plain too - could be assumed from the late fourth century. AltheIM 1962, 186-188, too dated the appearance of the Huns on the Hungarian Plain and in Pannonia to the close of the fourth century; at the same time, the idea that Valeria was surrendered to Ruga as a gift is also clearly present. These examples illustrate the impact of this moot point on archaeological research on the Hun period in Pannonia. Cp. Tóтн 2009, 174.

${ }^{288}$ E.g. То́тн 1989, 224; То́тн 2009, 174-175.

${ }^{289}$ PÁrduCZ 1974, 194-198 and 188 ("Auch die Feststel-

lungen von B. über die Ungarische Tiefebene sind unbeweisbar. Die Verlegung des hunnischen Machtzentrums gegen 420 nach Ungarn wird von gar keiner schriftlichen Angabe unterstützt und selbst die archäologischen Angaben machen die Möglichkeit nur in sehr geringem Maße wahrscheinlich.”) Their ongoing debate on various other historical and archaeological issues of the fourth and fifth centuries between 1961 and 1974 ended with M. Párducz's death in 1974.

${ }^{290}$ BÓNA 1991, 48-50.

${ }^{291}$ MAEnCHEN-Helfen 1973, 89-90; Soproni 1985, 105 , note 82 . He cites a written communication from Bóna, making it obvious that he had nothing else at his disposal. Bóna first put forward this historical reconstruction in his 1991 work (see the previous note).

${ }^{292}$ BÓNA 1987, 118; BóNA 1991, 252-253, 264, 267. In addition to the "short Hunnic chronology" based on a (construed) historical basis, a "long Hunnic chronology" (ca. 380-455) too gained ground in Hungarian archaeological research. The two chronologies have been used simultaneously since the debate between Párducz and Bóna.

${ }^{293}$ BÓNA 1991, 145, and 240.

${ }^{294}$ TOMKA 1996, 47-49 (the cited sentence is on p. 47). 
elicited fewer debates. Moreover, the occupation of the Hungarian Plain and the establishment of one of the empire's major power bases did not necessarily coincide. Thus, the creation of the principal imperial seat can probably be equated with the second or third phase of the occupation, and the continuity of Ruga's, then Bleda's centre during Attila's reign is merely assumed, but yet unproven. ${ }^{295}$ Thus, our scanty knowledge of the historical events is of limited value if used for dating the archaeological material, and it is wholly unsuitable for dating Hunnic cauldrons, most of which are stray finds.

How, then, can we date the cauldrons? We must certainly consider the claims that the Pannonian cauldrons and their formal counterparts from the Hungarian Plain represent the end of the typological sequence, which points towards a late date. The other potential chronological anchor is accepting the assumption that the use and deposition of cauldrons in these regions can be specifically associated with the Hunnic Empire, rather than with broadly eastern population groups, which similarly support a late date. Thus, their early dating to the close of the fourth century in the Carpathian Basin is causeless. ${ }^{296}$

\section{QUESTIONS OF FUNCTION AND RITUAL DIMENSIONS}

The cauldrons' function is generally assumed to be associated with funerary sacrifices. ${ }^{297}$ In international scholarship, this assumed function is often blended with an interpretation invoking ritual activities linked to water. Categorically opposing views are rare, ${ }^{298}$ and sometimes neither a ritual, nor a profane use of cauldrons is excluded. ${ }^{299}$ An earlier supposition that the vessels served as funerary urns for the ashes of Hunnic cremation burials has been definitely rejected. ${ }^{300}$

Two main directions can be distinguished in the funerary sacrifice theory. The first does not take a definite stand regarding the duration of the cauldrons' use, their owner, or who they were used by. The second clearly contends that they had been used during the presentation of sacrifices at the funeral of a Hun noble and that the burial associated with the cauldron should lie near the latter's findspot. ${ }^{301}$ Given that I. Bóna assumed a similar function for the Hunnic sacrificial finds, the burial of a Hunnic noble would theoretically be made up of a burial, a cauldron and a sacrificial assemblage. This interpretation assumes a single use for cauldrons and indirectly implies that the cauldrons had been the property of Hunnic nobles. ${ }^{302}$ In sum, this theory regards cauldrons as a spatially extended grave good.

I. Bóna thus believed that cauldrons could solely be linked to the funerary rite and in order to support this view, he cited forerunners which could be securely associated with burial rites. ${ }^{303}$ However, he also quoted pieces which he had excluded from the typological assessment and which are not all identified as Hunnic cauldrons in the eastern academic literature. This in itself calls for a re-assessment of this theory.

\footnotetext{
${ }^{295}$ To the best of my knowledge, only A. Alföldi assumed that Attila had shifted the earlier royal Hunnic seat farther north along the Tisza: ALFöLDI 1934², 44-45.

${ }^{296}$ E.g. Kovrig 1972, 120; Bierbrauer 2015, 446.

${ }^{297}$ BÓNA 1979, 301-302; BÓNA 1987, 118; BÓNA 1991, 140; BóNA 1991, 141; 189, 192. HARHOIU 1997, 133-134; КOCH 1997, 636; ANKe 1998, 51; КосH 2007b, 288-289; GoMOLKA-Fuchs 2007, 215; Rajtár-ZÁbojník 2010, 121. Fettich 1940 and Fettich 1953, 42 speaks about sacrificial cauldrons, but does not go into details regarding their specific function.

${ }^{298}$ Maenchen-Helfen 1973, 326 ("They were cooking vessels"). In Soviet scholarship, A. N. Bernstam assumed that cauldrons had been used as cooking vessels (БЕРнштАM 1951, 201, quoted
}

bу НудЕльман 1967, 308); for the reception of his work in Soviet research, see MAENCHEN-HelFen 1973, 190-198; at the same time, this view is fairly widespread among Russian scholars (ЗАСЕЦКАЯ 1994, 106)

${ }^{299}$ WeRnER 1956, 60; GHA 1987, 156, ÉRDY 1995, 7-8; Косн 1997, 636.

${ }^{300}$ KOVRIG 1972, 112-114; BÓNA 1991, 142-143.

${ }^{301}$ E.g. BónA 1991, 143, 192; see also above.

${ }^{302}$ This is expressed, e.g., by BÓNA 1979, 302: "Die teuren Kessel dürften nur bei dem Leichenmahl der vornehmen Hunnen gedient haben, auch dann zum letzten Mahl."

${ }^{303}$ BÓNA 1991, 143-144. 


\section{Precursors?}

Irrespective of whether or not Hunnic cauldrons had developed under direct impacts from Inner Asia, most scholars agree that these vessels were the products of a similar cultural complex as their steppean forerunners. This is underpinned by the probable similarities in their manufacturing technique and the shared decorative motifs such as mushroom-shaped ornaments, whose affinity with the cauldrons of the Scythian-Sarmatian period is generally accepted. ${ }^{304}$ Russian research has argued that this affinity should be conceptualised as a set of shared cultural traits, from which communities using the so-called nomadic cauldrons drew their inspiration for many centuries, despite the apparent regional and chronological distances between them. ${ }^{305}$ If the question of function is viewed objectively in the study of nomadic cauldrons, several similarities can be noted.

One of the distinctive traits of Hunnic cauldrons is that each piece is a unique product; other features noted by scholarship include the frequent signs of repair ${ }^{306}$ alongside traces of burning on their surface $\mathrm{e}^{307}$ and their deliberate damaging or fragmentation during their deposition. ${ }^{308}$ These are typical traits of earlier nomadic cauldrons too. The traces visible on the vessels are highly similar, even though they were recovered from different archaeological contexts, usually from burials. ${ }^{309}$ In the case of Scythian-Sarmatian cauldrons, these traces are in part interpreted as the marks of a distinctive manufacturing process (similarly to Hunnic cauldrons) and in part as a sign that cauldrons were prized possessions used for as long as possible and that they were principally used for preparing food (unlike Hunnic cauldrons). ${ }^{310}$

The intentional damaging or fragmentation of cauldrons was earlier already linked to the Sarmatian-Alanic world and likened to the well-known and thoroughly researched practice of breaking mirrors. However, I. Bóna rejected this parallel and argued that the deliberate damage inflicted on cauldrons was a Chinese and Inner Asian custom. ${ }^{311}$ He argued that the sooty-ashy traces of burning on the intact cauldrons, which are usually regarded as use-wear marks on the eastern cauldrons, were caused by the sacrificial pyre. ${ }^{312}$

Another commonplace in archaeological scholarship is that Hunnic cauldrons were much larger than their Scythian-Sarmatian predecessors and that they therefore had a different function. ${ }^{313}$ However, this contention cannot be substantiated because similarly to their form, the size of earlier nomadic cauldrons varied considerably. The volume of some Sarmatian cauldrons, for example, exceeds by far the volume of the Törtel cauldron. ${ }^{314}$

In the light of the above-cited analogies, the role of cauldrons in earlier nomadic cultures can hardly be neglected, even more so, since the rock carvings depicting cauldrons of the Yenissei regions are regularly cited in the assessment of Hunnic cauldrons too, ${ }^{315}$ despite the uncertainties in the dating of these petroglyphs and the fact that the depicted cauldron types were current on the steppe since the Scythian period. ${ }^{316}$ These rock carvings are usually

${ }^{304}$ Werner 1956, 59; Kovrig 1972, 100; MAENCHENHELFEN 1973, 331. BónA 1991, 146, too accepts this affinity, although he stresses their "Asian" connections.

305 БОТАЛОВ 2009, 230.

${ }^{306}$ БАТЧАЕВ 1984, 257-258; HARHOIU-DiACONESCU 1984, 100; ANKE 1998, 51.

${ }^{307}$ RÓMER 1870a, 292 (Törtel); НудЕЛЬМАН 1967, 306 (Şestaci); KovRIG 1972, 97 (Várpalota); Attila 2007, 114 (Razová). KOVRIG 1972, 112-113, notes that traces of burning can only be found on their exterior, an argument conceived for rejecting their use as funerary urns. For example, ash was found on the exterior of the Ioneşti cauldron, but the base interior was covered with a thick layer of slag (HARHOIUDiACONESCU 1984, 99). According to the description of the Benešov cauldron, its exterior was strongly damaged, while its interior was smoother. Among the early publications, KARGER 1940, 113, does not take a stand on whether this can be attributed to a casting fault or to secondary burning, while RASCHKE 1940, 115, claimed that the cauldron's condition could be explained by the strong burning of the vessel's exterior. 1984,100

${ }^{308}$ RÓMER 1870a, 291; cp. also HARHOIU-DIACONESCU

${ }^{309}$ Aside from burials, cauldrons and cauldron fragments have also been recovered from hoards and the fill of kurgans, and, similarly to Hunnic cauldrons, they have been discovered as stray finds (Боковенко 1978, 228; BÂRCĂ 2006, 164-167).

${ }^{310}$ БОКОВЕНКО 1978, 234-235; КоСЯНЕНКО-ФЛЁРОВ 1978, 200-201; BÂRCĂ 2006, 167.

${ }^{311}$ BÓNA 1991, 143. The dissociation of the custom of intentional damage from the steppean tradition is wholly groundless: $\mathrm{cp}$. Косн 1997, 643, note 29.

312 BÓNA 1991, 141.

${ }^{313}$ E.g. BónA 1979, 301.

${ }^{314}$ O. Maenchen-Helfen specifically pointed out that Hunnic cauldrons were considerably smaller than the Scythian ones (MAENCHEN-HeLFen 1973, 326). For the main types of Sarmatian cauldrons and their sizes, see Боковенко 1978, 229-233. To quote but a few more recently found Sarmatian cauldrons: the piece from Verkhniy Eruslan has a height of $54.5 \mathrm{~cm}$ with handles and $45 \mathrm{~cm}$ without handles, and a rim diameter of $42 \mathrm{~cm}$ (Kurgan 1, Burial 5: Юдин 1997; ДЕмиденко 2010); the height of a cauldron found during the 2013 excavation of a Sarmatian kurgan at Filippovka is $95 \mathrm{~cm}$, its diameter is $100 \mathrm{~cm}$ (Filippovka 1, Burial Mound 1: YABLONSKY 2015).

${ }^{315}$ For their distribution and detailed description, see ÉRDY 1995, 61, Figs 4 and 27-31; for the previous literature, see BóNA 1991, 221; КосH 1997, 642, note 18. 
cited in discussions of the cauldrons' function. ${ }^{317}$ The carvings can be seen as portraying the ritual use of the vessels, although, in Gyula László's words, they hardly exclude a funerary context ${ }^{318}$ - but then, neither do they confirm an interpretation along these lines because they could equally well commemorate a community rite or feast. ${ }^{319}$

Similarly to the rock carvings, cited as visual documents, we could equally well quote Herodotus' account $^{320}$ of Scythian customs, including a narrative on the Scythians' sacrificial rites, during which they cooked the meat of the sacrificial beasts in huge cauldrons (if the community possessed one). According to Herodotus, the custom of presenting sacrifices to various deities and the ancestors was quite widespread among the Scythians. ${ }^{321}$ He then goes on to describe the special sacrifice made to Ares, involving the veneration of a sword, ${ }^{322}$ which has an obvious relevance for the Hun period (for the Huns and Alans), even if it is no more than a topos commonly used by the historians of Antiquity. ${ }^{323}$ However, cauldrons are not expressly mentioned in relation to funerary customs in these sources. A poem by Claudius Marius Victor, a fifth-century rhetorician living in Marseilles, mentioning that the religion of the Alans involved the presentation of sacrifices to the ancestors, can be broadly associated with a general cult of the dead. ${ }^{324}$ Sacrificial customs expressly associated with the funerary rite are only found in Jordanes' narrative on Attila's funeral - there can be no doubt that the theory on funerary sacrifices was largely based in this passage. However, we know virtually nothing about the community rite enacted on the burial or memorial mound erected over the grave of the deceased king or in his memory (stravam super tumulum eius). ${ }^{325}$ Moreover, the very reliability of the description can be challenged, as can the extent to which the custom itself can be generalised. ${ }^{326}$

Finally, it should be noted that Z. Takács assumed that the Asian rock carvings depicted rites involving bloody animal sacrifices, a contention essentially based on Chinese sources and analogies. ${ }^{327}$ This theory, which I am not competent enough to judge, highlights the fact that there are no direct logical links between the individual elements of the traditional interpretation (an Inner Asian origin and funerary sacrifices).

\section{Parallels?}

Given the differing contexts of the complete cauldrons - separately deposited vessels or grave goods - another point must also be discussed. To date, O. Maenchen-Helfen is the only scholar who suggested that cast cauldrons were not the only vessels that had probably been used for special purposes and that vessels of different cultural origin and representing various workshop traditions had probably had similar functions - likewise, cauldrons may have had several functions too. ${ }^{328}$ Viewed from this perspective, it is more understandable why Hunnic cauldrons had been deposited in burials in regions where metal cauldrons had been deposited as grave goods during earlier periods too, ${ }^{329}$ and where metal cauldrons representing other technical and formal variants also occur in the grave inventories.

It seems likely that the large sheet metal or cast bronze buckets and situlas recovered from late Roman- and early Migration-period burials on the Eastern European steppe and the Caucasian foreland can be regarded as functional analogies to the cast nomadic cauldrons. ${ }^{330}$ The finds from the cemetery at Khabaz yielded not merely a Hunnic cauldron, but also two other bronze vessels of differing sizes. ${ }^{331} \mathrm{~A}$ bronze bucket was found together with

${ }^{316}$ As noted, e.g., by BónA 1991, 142 and KocH 1997, 636; KосH 2007b, 288-289.

${ }^{317}$ WERnER 1956, 57, 60; MAENCHEN-HELFEN 1973, 326 327; BÓNA 1979, 302; BÓNA 1991, 141-142; ANKE 1998, 51. For further depictions, see WosinsKy 1896, 992; FETTICH 1953, XXVI/16-24; TAKÁCS 1955, Abb. 33; LÁSZLó 1974, 38, 13a-c.

${ }^{318}$ LÁSZLÓ 1974, 39-40.

${ }^{319}$ Cp. MAenChen-Helfen 1973, 326-327.

${ }^{320}$ E.g. by HAMPEL 1893, 398

${ }^{321}$ Herodotus IV, 60-61.

${ }^{322}$ Herodotus IV, 62.

${ }^{323}$ Ammianus 31, 2, 23, Iordanes 35, 183; Priscus fr. 12.

${ }^{324}$ Claudius Marius Victor, 189-200, cited by BACHRACH
${ }^{325}$ Iordanes 258

${ }^{326}$ TOMKA 2007, 253-254

${ }^{327}$ TAKÁCS 1925, 212.

${ }^{328}$ MAENCHEN-Helfen 1973, 323.

${ }^{329}$ For the distribution of late Sarmatian cauldrons, see БотАлов 2009, 232, Fig. 59.

${ }^{330}$ Амьро3 1989, 36, Figs 9-10, for the pieces from the northern Caucasus; for an overview, see ЗАСЕЦКАЯ 1994, 108-109; Simonenko 2007, 18. Most Central European scholars regard the deposition of this cauldron type in burials in the Danube region as a general Alanic-Sarmatian influence, cp. TEJRAL 2011, 101; TEJRAL 2012, 319, and BóNA 1991, 183.

${ }^{331}$ БАТЧАЕВ 1984, Fig. 1, 17, 20.

$1973,31-32$ 
the Hunnic cauldron, both in a strongly damaged condition, in the earth of the Malai kurgan. ${ }^{332}$ The bronze vessel of the Hun-period sacrificial assemblage from Makartet, which was earlier regarded as possibly being a cast cauldron, can be assigned to the same group. ${ }^{333}$ As it turned out, however, the vessel was a hammered sheet metal cauldron in a damaged condition, as reported in the full publication of the assemblage. ${ }^{334}$ The fluid boundary between types, functions and depositional practices is underpinned by the fact that another smaller metal vessel was found alongside the Hunnic cauldron at Jędrzychowice ${ }^{335}$ and Şestaci. ${ }^{336}$ A detailed study of the volume of the various vessels found in burials and in deposited assemblages would no doubt contribute to a better understanding of the vessels' functions.

The cauldron from the Malai kurgan is the single piece that can probably be dated to well after the Hun period. The cauldron was recovered from a unique context among the Hunnic cauldrons. The burial rite reflected a blend of Sarmatian and Eastern European Hunnic traits as well as features of the Shivashovka horizon. At the same time, there are no truly good analogies to the burial practices reflected by the finds recovered from the kurgan's earth and the ditch enclosing it (horse and cattle remains, clay pottery, smaller metal artefacts and the fragments of two cauldrons). ${ }^{337}$ The horse bones and skulls, the pottery and the cauldrons as well as the circular ditch enclosing the kurgan can perhaps be likened to the funerary rite of middle and late Sarmatian tumuli. In addition to the burnt layers in the earth of the tumuli and the ditches enclosing them, the animal bones and a larger amount of smashed pottery and amphora finds, the more lavishly outfitted burials contained also Roman bronze vessels, silver vessels, silver harness ornaments, nomadic bronze cauldrons and their fragments. ${ }^{338}$ According to one interpretation, these could be the remains of a funerary feast or the remnants of periodically enacted rituals - the two cannot be clearly separated and there is perhaps little sense in doing so.

The continuity of this Sarmatian-period rite is uncertain and calls for further studies. What seems certain is that the Hunnic cauldrons deposited in burials echo the earlier burial customs and rites of the broader region. These traditions have only been documented in the Kuban region, the Caucasus and the southern Ural region, i.e. in the earlier Sarmatian-Alanic territories, and it is therefore hardly mere chance that Hunnic cauldrons have not been found in expressly funerary contexts west of these regions.

There are two curious western finds in this respect. The first is the Törtel cauldron, which similarly to the exemplar from Malai, was most likely found on what was probably a prehistoric kurgan. The other is the more archaic Jędrzychowice cauldron, which probably comes from a sacrificial assemblage rather than a burial. ${ }^{339}$ In addition to the sacrificial assemblages known from the Central European territory of the Hunnic Empire, the Katzelsdorf hoard found a few years ago can also be assigned to this category. ${ }^{340}$ As far as I know, neither Hun-period assemblage can be associated with a burial, and thus these finds parallel Hunnic cauldrons in terms of their contexts.

It is disputable to what extent the above-cited analogies, far removed in space and time, are relevant for Hunnic cauldrons and whether they can be used as direct parallels. Still, they represent the closest parallels to the archaeological material. The similarities are supported by their condition (traces of burning, intentional damage, fragmentation) and the only difference is one of archaeological context. However, this does not necessarily imply a complete change in their function. The distribution of cast cauldrons indicates that the change of context can be noted in the regions of the Hunnic Empire lying west of the Volga-Don region.

Quite typically, stray finds of cauldrons are generally assumed to have had some ritual role, while the pieces recovered from burials and the fragments found in Roman forts are believed to have been put to profane uses.

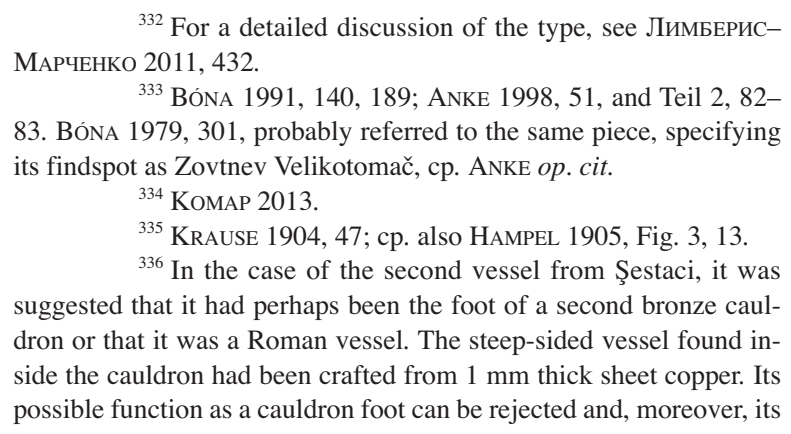

${ }^{332}$ For a detailed discussion of the type, see ЛимьеРисMАРЧEHKO 2011, 432.

${ }^{333}$ BÓNA 1991, 140, 189; ANKE 1998, 51, and Teil 2, 8283. BóNA 1979, 301, probably referred to the same piece, specifying its findspot as Zovtnev Velikotomač, cp. ANKE op. cit.

${ }^{334}$ KOMAP 2013.

${ }^{335}$ Krause 1904, 47; cp. also Hampel 1905, Fig. 3, 13.

${ }^{336}$ In the case of the second vessel from Şestaci, it was suggested that it had perhaps been the foot of a second bronze cauldron or that it was a Roman vessel. The steep-sided vessel found inside the cauldron had been crafted from $1 \mathrm{~mm}$ thick sheet copper. Its possible function as a cauldron foot can be rejected and, moreover, its

form is uncommon among metal vessels. The vessel wore thin and was repaired, and became deformed in Antiquity. Its side is burnt, similarly to the cauldron, and it was therefore interpreted as a cooking vessel. НудЕЛЬмАН 1967, 306-307, ris. 2; quoted, e.g., by KovRIG $1972,114$.

337 ЛИМБЕРИС-МАРЧЕНКО 2011, 437-438.

${ }^{338}$ КосянЕНко-ФЛЁРОВ 1978, 197, 203; ВА̂RСӐSYMONENKO 2009, 107-108, 213.

${ }^{339}$ MAENCHEN-HELFEN 1973, 327-329; RAJTÁR-ZÁBOJNÍK 2010, 121; TEJRAL 2011, 332, 350-351. It was interpreted as a grave find by Косн 1997, 641, note 12; ANKE 1998, 51.

${ }^{340}$ MÜLLER-Novotny 2014. 
It has been mentioned in the above that the fragments brought to light in Roman forts have also been regarded as scrap metal, an interpretation proposed for explaining why cauldrons had been deliberately broken into smaller pieces as at Celamantia and Sucidava. Several eastern cauldrons have since been found in a similar condition, broken into small fragments. Among these, the most important are the ones that could be wholly or partially refitted from the fragments (Perevolotchna, Samara, Tsimlyansk, Malai). In these cases, their preparation for remelting and then burying the pieces seems unlikely. It seems more probable that this fragmentation merely represents another form of deliberate damage to cauldrons - some pieces are brought to light "slashed apart" (for example, the exemplars from Törtel, Várpalota, Rádpuszta and Ioneşti).

Several stray finds of small cauldron fragments from various barbarian contexts are now known as a result of metal detecting activities (Lichnov, Ócsa, Sudiţi and the three fragments from Buzhor), for which a variety of explanations can be offered: it is possible that the burial of the fragments was not part of the rite, only the fragmentation and the intentional damage; another possibility is that only part of the vessels was deposited, and neither can secondary effects on the vessels be excluded. Whichever the case, these finds demonstrate that the material from the Roman forts can hardly be divorced from the overall assessment of cauldrons. Deliberate fragmentation as a ritual activity may also have been practiced in Roman forts. ${ }^{341}$

In the light of the above-cited parallels and analogies, the separation of the ritual and profane role seems unwarranted. ${ }^{342}$ All we can presume is that the vessels were material expressions of cultural memory. ${ }^{343}$ It also seems likely that cauldrons played a prominent role in community rituals, a function repeatedly suggested in view of their large volume, although, curiously enough, western scholarship favours their use in preparing intoxicating or narcotic beverages, while Russian research, in contrast, the preparation of food. ${ }^{344}$ It remains uncertain in which societies they assumed a role in funerary rituals. The stray finds are hardly suitable for resolving this issue. For example, O. Maenchen-Helfen assumed that cauldrons are lacking from among grave goods because they were owned not by individuals, but by a larger group. ${ }^{345}$ Thus, their direct association with high-ranking individuals remains uncertain.

Among the counter-arguments to the use of cauldrons for preparing meals - whether as part of a ritual or not - the perhaps weightiest is the contention that other vessels would also have been suited to this purpose ${ }^{346}$ One useful approach in this case is that similarly to ceramic utensils, metal vessels probably played a role as mediums of communicating identity. We know from archaeological anthropology studies that pottery styles could also express a wide range of messages. ${ }^{347} \mathrm{~A}$ similar contention, proposed earlier, is that the more or less uniform appearance of cauldrons can perhaps be explained by their role in community rituals, which left little space for individual forms and decorative patterns. ${ }^{348}$

Thus, it seems unlikely that these vessels had been made for a single funerary sacrifice. The deliberate damage to the cauldrons rather suggests that the vessels - at least the intact pieces - are generally found in the location where they were ritually put out of use. Whether this location is identical with the scene of the ritual activity 349 and whether the latter can be linked to funerary rites can hardly be determined - what seems certain is that their deposition represented the last act of the rite.

The examination of the Ócsa cauldron indicated that it had been exposed to high temperatures for a longer time (see the Appendix for the detailed results of the SEM EDS analysis). This wholly new observation in the research on cauldrons supports arguments that the cauldrons had been used for various purposes prior to their deposition.

\footnotetext{
${ }^{341}$ Cp. Bierbrauer 2015, 446.

${ }^{342}$ Cp. Werner 1956, 57; Maenchen-Helfen 1973, $326-327$.

${ }^{343}$ As defined by Assmann 2011, 15-33.

${ }^{344}$ See above. Cp. Бернштам 1951, 201; Rómer 1870a, 292, who in his publication of the Törtel cauldron suggested that it had been used as a liquid container or mixing vessel in view of its form. Cp. WERNER 1956, 60, who raised the possibility that cauldrons had perhaps served for the preparation of alcoholic beverages (camum, cp.
}

Priscus fr. 11), a view also regarded as plausible by Franz Altheim (Altheim-Haussig 1958, 51).

${ }^{345}$ Matenchen-Helfen 1973, 327.
${ }^{346}$ Kovrig 1972, 114.
${ }^{347}$ Rice 1987, 266-269. Cp. BlinKhorn-Brown 2015, citing Anglo-Saxon examples, and JeRvis 2015, discussing various levels of identity.

\footnotetext{
${ }^{348}$ ANKE 1998, 50.

${ }^{349}$ As assumed by MAENCHEN-HeLFEN 1973, 327.
} 


\section{Iconology?}

The iconological aspect of cauldrons must also be briefly addressed. This practically means the interpretation of the mushroom-shaped handles, the "crown". Three interpretations have been advanced so far: the so-called pseudo-brooch theory, ${ }^{350}$ the contention that the handle represents a crown and thus a symbol of power, ${ }^{351}$ and that it is a stylised version of the Tree of Life. ${ }^{352}$

In fact, the three separate interpretations are closely intertwined. It has been repeatedly noted that the decorative element "crowning" Hunnic cauldrons bears a striking resemblance to the diadems of the Hun period. ${ }^{353}$ Given that the decorative motifs of the gold diadems of the Sarmatian-Alanic period, regarded as the precursors of Hunnic diadems, also include tree motifs, ${ }^{354}$ the "Tree of Life" can hardly be separated from the "crown" because the two motifs blend in the iconography of diadems. ${ }^{355}$ Earlier scholarship, especially in Hungary, did not particularly emphasise this aspect because the Tree of Life motif was believed to have a shamanistic relevance. ${ }^{356}$

The idea that cauldrons were "crowned" was first proposed by Gy. László. ${ }^{357}$ However, as I. Bóna demonstrated, at the time this theory was conceived, László regarded cauldrons as funerary urns and he therefore sought analogies to the anthropomorphisation of cauldrons among funerary vessels. ${ }^{358}$ This supposition can no longer be accepted because its springboard has been disproven. Still, it might be instructive to revisit this contention from other aspects. ${ }^{359}$

From the very beginning of research on cauldrons, the obvious resemblance between the handle motifs and the semi-circular head of large plate brooches was noted. ${ }^{360}$ However, this simple depiction could only be convincingly labelled a pseudo-brooch motif if, similarly to the depictions on cauldrons and diadems, the brooches were worn with the semi-circular head pointing upward. In contrast to Flóris Rómer, who first suggested this analogy, we now know that these brooches were worn in the exact opposite manner, and thus the cognitive background is much more uncertain. ${ }^{361}$

Still, the use of all three artefact types (cauldrons, diadems and plate brooches with semi-circular head) can be linked to the Hunnic movement, and while cauldrons and diadems later disappeared, brooches remained in use, although their form changed after the Hun period. Thus, the assumption that the widespread appearance of the motif can be attributed to a shared ideological background (the expression of an imperial identity, for example) seems acceptable. This issue can only be resolved by a detailed study of the Hellenistic and late antique precursors of insignia. ${ }^{362}$

Cauldron handles were unsuitable for suspending the vessels for a longer time, and their form too belies this usage, as does the lack of use-wear marks indicating suspension. ${ }^{363}$ At the same time, the suggestion that the handles were useful for removing the cauldrons from fire seems acceptable. ${ }^{364}$ While this functional explanation assumes the active use of cauldrons, it does not exclude the more abstract meaning of handles.

\footnotetext{
${ }^{350}$ The similarity was already noted by RÓMER 1870a, 292. The Pseudofibelbedeutung theory was later elaborated by Nándor Fettich (FetTich 1940, 247-248; Feтtich 1953, 40-42).

${ }^{351}$ E.g. Werner 1956, 57; HARHOIU 1997, 133.

${ }^{352}$ E.g. Kovrig 1972, 110, and BÓNA 1991, 146, ЗАСЕЦКАЯ 1994, 106, after Kovrig.

${ }^{353}$ E.g. Werner 1956, 59; Harhoiu 1997, 133; AnKe $1998,36$.

${ }^{354}$ E.g. AnKe 1998, 32-33; IstvánOvits-Kulcsár 1997, 157-158; ProKHOROVA 2001, 222-223 (Kat. 239).

${ }^{355}$ A point noted by Werner, although from another aspect (WeRner 1956, 69-74). For a critique, see Altheim-Haussig 1958, $53-56$.

${ }^{356}$ E.g. KovRIG 1972, 110.

${ }^{357}$ LÁSZLÓ 1974, 38-40. The interpretation as a shaman's crown was already challenged by FETTICH 1953, 42, note 47.

${ }^{358}$ BÓNA 1971, 269.

${ }^{359}$ Gy. László merely noted the anthropomorphic depictions of Scythian cauldrons, but did not discuss other figural art (LÁsZLó 1974, 40). These are now generally associated with sacrificial
}

rituals and an intermediatory role is ascribed to them (КосянЕНкоФЛЁРОВ 1978, 203-204; БОКОВЕнко 1978, 232; ВÂRС̆̆ 2012, 194; Курчатов-Тельнов 2010), and the possible relation with Chinese ceremonial bronze vessels has been suggested in the case of certain special vessels (СКРИпкин 2000).

${ }^{360}$ This was one of Rómer's arguments for dating the Törtel cauldron to the Migration period (RÓMER 1870a, 292) and likening it to the piece from Jędrzychowice, even though the associated finds were not known at the time (RÓMER 1870b).

${ }^{361}$ The variant of this idea proposed by N. Fettich was refuted by KOVRIG 1972, 108-110.

${ }^{362}$ Along roughly the same lines as proposed by Franz Altheim in relation to diadems: AltheIM-Haussig 1958, 53-54, cp. KovRIG 1985, 132-137; DAMm 1988, 105-107; ANKE 1998, 36.

${ }^{363}$ WeRnER 1956, 60; KovRIG 1972, 112.

${ }^{364}$ Cp. MaEnCHEN-Helfen 1973, 326, who also suggested that hooks had perhaps been used for this purpose too, as depicted on the rock carving of Pisannaya Gora. For the depiction, see ibid. Fig. 52. This view is echoed, e.g., by РЕДІнА-РосоХАЦькИЙ 1994, 153. 


\section{SOCIAL ORGANISATION OF THE HUNNIC EMPIRE}

The contextualisation of Hunnic cauldrons, the reconstructions of their function and their dating are closely allied to the views on the organisation of the Hunnic Empire, even if these notions are rarely discussed in detail. The separation of the archaeological material according to the different population groups living in the Hunnic Empire, the possibilities of ethnic attribution and the relations between Romans and barbarians are all continuously debated issues. Cauldrons represent virtually the single artefact type that is generally associated with the Huns, ${ }^{365}$ their findspots are generally associated with Hunnic power bases and their discovery is generally expected in the Hunnic Empire's central regions. ${ }^{366}$

Underlying these ideas is the presumption according to which the "Asian Huns" were concentrated in the Hunnic Empire's central regions, while the "vassal" peoples and population groups lived around them. An entirely different social theory played a prominent role in earlier archaeological research, which assumed that the small, mobile, Hunnic military groups were essentially scattered across the empire's entire territory. It is possible that the greater acceptance of this model would have paved the way for the interpretation of the archaeological material along other lines in the later twentieth century. ${ }^{367}$

\section{Theories on the social organisation of the Hunnic Empire in Hungarian scholarship}

The theory of the "ring of vassal peoples", contrasting sharply with the previous theory, represented a new historical-archaeological narrative that was formulated in the late 1940s and the 1950s in opposition to the research attitudes of the pre-war period. ${ }^{368}$ One important element of the theory from an archaeological perspective was that only lavishly outfitted Hunnic burials and the poorer graves of slaves and of freemen cast into personal dependence could be expected on the settlement territory of the slave-holding Huns. The subjected peoples had their own independent political and social organisations, implying that they had their own settlement territories and that their archaeological material could be identified. The Hun-period archaeological material was thus used for illustrating the crisis of gentile society, the disintegration of clan society and the emergence of military democracy. This theory fitted in neatly with the new cultural policy, which explicitly encouraged ethnic archaeology and historic approaches in the study of the Migration period. ${ }^{369}$

In later decades, the ideology underlying the theory faded and the narrative assumed a life of its own. This can in part be attributed to the fact that more recent comprehensive overviews were generally intended for the broader public ${ }^{370}$ and thus it is more difficult to assess the broader impact of the theory and to deconstruct it. At the same time, Hungarian texts on the social organisation of the Hunnic Empire reflected the ideological influence of the 1950s for many decades and this also had an immense impact on the interpretation of the archaeological mate-

${ }^{365}$ E.g. Koch 1997, 637; HEATHER 2009, 229; BIERBRAUER
2015, 445-446.
${ }^{366}$ See the relevant section above. Moreover, efforts to identify the "eastern nomadic heritage" in the Danube region is one of the major concerns in archaeological scholarship: see, e.g., BóNA 1991, Abb. 69 (Kartenbeilage); TeJRal 2010, TeJRAL 2011, 330-346, Abb. 228, 280

${ }^{367}$ For the so-called "Kosakenteorie”, see ALFÖLDI 1932, 35-36; for its critique, see BÓNA 1971, 266-267; for a similar social theory, see BurY 1923, 100-103; VÁCZY 1940, 97-110; cp. HEATHER 2009, 214-217. This was most eloquently expressed by VÁCZY 1940 , 101-102: "the peoples retained their independence in the empire. They did not assimilate to each other, but adhered to one another as grains of sand." Similarly to the issue of the relocation of the power base, there is an "invisible" research direction, which does not take a definite stand on this matter, e.g. WoLFRAM 1979, 309-317, who accepts that virtually nothing is known about the fate and the settlement territory of the Ostrogoths and other Germanic groups under Hunnic overlordship between 375/376 and 451 .
${ }^{368}$ Most clearly by LÁszló 1951; Harmatta 1951; HARMATTA 1951b, 99-100; HARMATTA 1953, 108-109.

${ }^{369}$ This new theory ensured the legitimacy of archaeological research and thus resulted in several major studies. J. Harmatta's cited forewords are an excellent example: these legitimised, in terms of social theory, the studies by N. Fettich, who had been stripped of his membership in the Hungarian Academy of Sciences by this time - Fettich's archaeological studies were written with an art historical perspective that was deemed undesirable by the period's cultural policy. This is one of the reasons that the detailed investigation of the archaeology of the Hunnic period's elite flourished in the very years in Hungary during which the emphasis was on the commoners in the research of other period (e.g. the Middle Ages). This paradigm shift and its impact on scholarship has not been explored in detail. For the Engelsian roots of Soviet social theory, its main directions and its critique - including Harmatta's work - see MAENCHEN-HELFEN 1973, 190-198.

${ }^{370}$ For one of the first critiques of the comprehensive theories disseminated as part of public education, see PÁRDUCZ 1974, 188. 
rial. ${ }^{371}$ This is the main reason that of the lavish Hun-period assemblages from Hungary, only the Nagyszéksós Treasure from the central region of the Hungarian Plain and the Szikáncs gold hoard were previously regarded as relics of the Huns. ${ }^{372}$ The Hunnic cauldrons from Pannonia were simply "omitted" from this social narrative.

In Hungary, studies offering a different, more complex reconstruction were written by the older generation of scholars, but these never took root in the academic literature of the later twentieth century. ${ }^{373}$ In more recent historical studies, the social reconstruction by Peter Heather, for example, reflects an approach untouched by the Marxist view of history. In his narrative, the last grand period of the Hunnic Empire was characterised by a lack of powerful leaders exactly because of the need to the keep the empire together. This is supported not only by the written sources, but also by the long turmoil following Attila's death. ${ }^{374}$

Similarly as in a host of other issues, I. Bóna's late monograph is a mix of different narratives, which essentially reflect the different phases of a scholarly attitude and its successive changes. The broad outlines of a new picture emerged slowly and indicated that the Hun-period finds and assemblages from Hungary show a concentration not in the central region of the Hungarian Plain, but in Pannonia and in the fringe territories such as the Upper Tisza region. Bóna emphasised that this can be explained by the empire's military organisation and he directly associated Hunnic cauldrons with this theory. ${ }^{375}$ The Militärzone or Hunnenschild theory in itself indicates that the earlier theory was no longer tenable and he linked the lavish finds and the cauldrons to the empire's aristocracy and their armed retinues. At the same time, the historical-ethnic approach and the belief that peoples could be identified and separated based on the archaeological record is reflected in his view that the Pannonian Hunnenschild was exclusively made up of eastern, non-Germanic population groups. ${ }^{376}$

\section{New avenues in interpretation}

Restricting the issue of social aspects to cauldrons, we may say that the finds do not conclusively indicate that these artefacts can be exclusively linked to the uppermost layers of society and, in any case, being mostly stray finds, they are unsuitable for any conclusions in this respect. As we have seen, neither is this assumption supported by their possible function because their archaeological parallels tend to support a broader role in community rituals rather than one in the funerary rites of the social elite.

It was earlier noted that cauldrons appear to show a concentration on the empire's western fringes, on Roman soil, and not in the central settlement area of the Barbaricum in the Carpathian Basin. Neither does the distribution of cauldrons coincide with the assumed Hunnic power bases in Wallachia, in the Lower Danubian region, where - in contrast to Pannonia - the border was linear. The cauldrons cannot be squeezed within narrow chronological boundaries and their typological analysis too suggests that there were direct contacts between the various regions of their distribution up to the very end of their formal development. This would imply that the

${ }^{371}$ See BÓNA 1965, 116-117, for the subjugated population of the Hungarian Plain; BóNA 1968, 113-115, for an open critique of the earlier theory and the centralism of the Hunnic Empire, which in his interpretation meant a concentration of military power in the empire's strategic centre; BóNA 1971, 268-269 ("Völkerring aus Vasallen”); BÓNA 1984, 266, 285-287; BÓNA 1987, 117-118. Obviously, these views were not restricted to Hungarian scholarship (e.g. MitrEA 1961, 555-556), but a discussion of this issue would exceed the scope of this study.

${ }^{372}$ E.g. by HARMATTA 1953, and, after him, BÓNA 1968; BóNA 1971, 268-269. Later, this theory was no longer promoted, although without openly challenging the ideological background. BóNA 1979,302 , noted that he had earlier subscribed to this view, but this was no longer the case - cp. BÓNA 1991, 224, mentioning only Harmatta in this respect.

${ }^{373}$ Cp. PÁrduCZ 1959, 384-385, whose reconstruction of the social organisation in the heartland of the Hunnic Empire based on the archaeological material was as follows: "aristokratische Schicht"
- "Sippenhauptlinge?" - "Krieger" - "Handwerker" - "die Urbevölkerung, die Knechte und Kriegsgefangene”. Cp. ibid. 309-310, for a discussion of the research findings of László and Harmatta, and for the need to study the broader population groups. CsallánY 1961 , 335-345, took Párducz's assessment as his starting point for the Hungarian Plain in the fifth-sixth centuries, and reckoned with a sizeable commoner population during the Hun period. For its reception in Hungary, see BóNA 1963. On the historians' side, VÁCZY 1940, 104-105, too rejected the dispersal of the subjugated peoples and the transformation of their society in the Hunnic Empire.

${ }^{374}$ HEATHER 2009, 221-238, esp. 233-235.

${ }^{375}$ BÓNA 1991, 201, 264 and 144: "alle übrigen im Karpatenbecken gefundenen Kupferkessel aus der das hunnische Zentrum verteidigenden pannonischen Militärzone, wo auch die Mehrzahl der hunnischen Funde zum Vorschein kam.” For the early formulation of this theory, cp. BóNA 1979, 315 ("Verteidigungsgürtel" and "Oberkommando der Verteidigung").

${ }^{376}$ BÓNa 1991, 201. 
cauldrons concentrated in the empire's western and southern frontier zones are an indication of the broader communities that emerged on the Hunnic Empire's border. ${ }^{377}$

We have no reason to doubt that the cauldrons can be associated with the ritual traditions, perhaps including funerary rites, of communities of eastern ancestry. However, other plausible explanations should be sought aside from an ethnic one. Modern archaeological scholarship has repeatedly demonstrated that most of the period's artefact types cannot be linked to a specific ethnic group only. Why would cauldrons be an exception?

An artefact type that can be seen as a cultural hallmark ${ }^{378}$ distributed across such an extensive area, which disappeared without a trace after a brief floruit, ${ }^{379}$ in itself evokes the associations of an emblem of the empire. Irrespective of the ritual activities that can be possibly associated with them, cauldrons undoubtedly strengthened cohesion among the individuals who participated in these manifestations of cultural memory. It seems quite reasonable that in society geared to military offensives, the artefacts embodying the empire's cohesion show a concentration in the frontier zones and in smaller oft-frequented regions, resembling in this respect the Roman limes, along which entirely different elements of material culture play a prominent role than on the settlements of the civilian population. ${ }^{380}$

The assessment of the Pannonian material from this aspect is extremely difficult, given that the region was a frequented frontier zone not only of the Hunnic, but also of the Roman Empire during a few successive decades. ${ }^{381}$ Cauldrons and other sacrificial assemblages made up of splendid precious metal artefacts provide the clearest evidence of the various forms of social display on the Roman and the Hunnic side of the imperial border. ${ }^{382}$

Accepting an interpretation as an expression of "imperial identity" also means that the Germanic communities of the Hunnic Empire cannot be excluded from among the users of cauldrons, even if the evidence suggests that the beliefs associated with cauldrons do not originate from the Germanic world. ${ }^{383}$ Cauldrons cannot be identified as "non-Germanic" (i.e. as "reiternomadisch-hunnisch") artefacts just like the ethnic attribution and interpretation of the assemblages regarded as the heritage of Germanic peoples should be left open during the Hun period. In the light of the fierce debates over the Roman-barbarian bipolarity during the past decades, we may say that the Germanic-non-Germanic "barbarian dichotomy" so deeply rooted in European scholarship would also merit a broader discussion. Still, we have no reason to assume that there was no Hunnic or a broader imperial identity during this period. On the contrary: on the testimony of the written sources, the social fabric of the rapidly transforming Hunnic Empire involved the emergence of new group identities, ${ }^{384}$ which, however, were not necessarily reflected in the material culture, although we may expect their reflection in the archaeological material in exceptional cases. Hunnic cauldrons appear to represent one such exceptional case.

${ }^{377}$ For late antique military frontier societies, see, e.g., SARTI 2015; for their material culture, see COULSTON 2013.

${ }^{378}$ BóNA 1979, 303; cited by HARHOIU-DiACONESCU 1984, 100.

379 "Das plötzliche Verschwinden [...] ist ein nur schwer erklärbares Phänomen.” ANKE 1998, 55. Moreover, we cannot simply assume that cauldrons disappeared from the archaeological record merely owing to a change in practiced rites because the disappearance of Hunnic cauldrons also marked the end of the millennia-old technology of casting bronze vessels on the Eurasian steppe (WERNER 1956, 60; BÁLINT 2010, 217-247).
${ }^{380}$ Hodder 1974, 355; vON Hesberg 1999. In the case of the Roman Empire, quite obviously, the different demands and distribution options (roads, markets) can be much better documented than during the Hun period.

${ }^{381} \mathrm{Cp}$. TeJRAL 2011, 346.

${ }^{382}$ For a discussion, see vON RUMMEL 2007; BRATHER 2007; BIERBRAUER 2015; EGER 2015.

${ }^{383}$ Cp., e.g., ANKE 1998, 54, who assumes the use of cauldrons solely in Sarmatian, Alanic and Hunnic milieus.

${ }^{384}$ HeATHER 2009, 235-237: "Because being a Hun meant higher status, the Empire's multicultural character effectively erected barriers around Hunnic identity." 


\section{CATALOGUE OF HUNNIC CAULDRONS ${ }^{385}$}

Poland

1. Jędrzychowice; Dolnośląskie/Lower Silesian Voivodeship (earlier variants of the name: Höckricht, Bezirk Ohlau)

Czech Republic

2. Lichnov; Nový Jičín District, Moravian-Silesian Region

3. Razová, Bruntál District, Moravian-Silesian Region (earlier variants of the name: Bennisch, Raase, Bezirk Troppau; Benešov)

Slovakia

4. Iža, Leányvár (Celamantia); Komárno District

Hungary

5. Balatonlelle-Rádpuszta, Temetőalja-dülö, Site 67/4; County Somogy

6. Dunaújváros (Intercisa); County Fejér

7. Kapos Valley, between Hőgyész and Regöly; County Tolna (erroneous variant of the findspot: Kurdcsibrák)

8. Ócsa, Felsőbabád, Kincses-hegy; County Pest

9. Törtel, Czakó-halom; County Pest

10. Várpalota; County Veszprém (erroneous variant of the findspot: Bántapuszta)

Romania

11. Boşneagu; commune Dorobanţu, Călăraşi County

12. Celei (Sucidava); part of Corabia, Olt County

13. Desa, between Ciuperceni and Ghidiciu; Dolj County

14. Hinova (castrum); Mehedinţi County

15. Hotărani; commune Vânjuleţ, Mehedinţi County

16. Ionești; commune Petrești, Dâmbovița County

17. Sudiţi; commune Gherăseni, Buzău County

18. Unprovenanced handle fragment from a Wallachian collection (not marked on the map)

Moldavia

19. Şestaci; Şoldăneşti District (called Rezine before 1980)

Ukraine

20. Ivanovka/Ivanivka; Svatovskyie District, Luhanska Oblast (?) (earlier variant of the name: Ivanovski, Ivanovskaja staniza, Yekaterinoslav Governorate)

21. Olbia Pontica; Ochakivskyi District, Mykolayivska Oblast

22. Perevolotchna; Kobeliatskyi District, Poltavska Oblast (earlier variant of the name: Perevolotchnaya)

23. Tymkove; Kodymskyi District, Odeska Oblast (earlier variant of the name: Timkovo)

Russia

24. Buzhor; Krasnodarskiy Kray

25. Khabaz, Shiyakky-Kol; Kabardino-Balkar Republic

26. Kyzyl-Adyr; Kuvandykskiy District, Orenburgskaya Oblast

27. Lipnyagova; Shadrinskiy District, Kurganskaya Oblast

28. Magas, Nasyr-Kort; Republic of Ingushetia

29. Malai; Krasnodarskiy Kray

30. Samara; Samarskaya Oblast

31. Simferopol (Neapolis Scythica); Republic of Crimea

32. Soka; Karsunskiy District, Ulyanovskaya Oblast (earlier variant of the name: Simbirsk Governorate; erroneous variants of the findspot: Osoka, Otoka, between Otoka and Zagarina)

33. Suncheleyevo; Republic of Tatarstan

34. Left bank of the Tsimlyansk reservoir; Volgogradskaya Oblast

35. Verkhniy Konets; Ust'-Kulomskiy District, Komi Republic (earlier variant of the name: Verkhniy Konets, Vologodskaya Oblast, Ust'Sysolski Raion; erroneous variant of the findspot: "Verchnij Konec an der Dvina")

China

36. Nanshan; Ürümqi, Xinjiang Uyghur Autonomous Region

Unprovenanced

37. Vienna purchase (most frequently specified erroneous findspot: "Troyes?"; not marked on the map)

${ }^{385}$ Listed in the catalogue is the current name of a site or findspot, the antique place name (if any) and the most important changes in the designation of a site or findspot. For further biblio- graphical data, see the earlier literature, esp. BÓNA 1991; ÉRDY 1995; Косн 1997; ANKE 1998. 


\title{
APPENDIX
}

\author{
XRF AND SEM EXAMINATION OF THE HUNNIC CAULDRON FRAGMENT FROM ÓCSA
}

\section{PÉTER BARKÓCZY-ZOLTÁN MAY}

\author{
Institute of Physical Metallurgy, Metalforming, \\ University of Miskolc, H-3516 Miskolc-Egyetemváros, Hungary \\ peterbarkoczky@fux.hu \\ Institute of Materials and Environmental Chemistry, \\ Research Centre for Natural Sciences. Academy of Sciences \\ Magyar tudósok körútja 2., H-1117 Budapest, Hungary \\ may.zoltan@ttk.mta.hu
}

The XRF analysis of the cauldron fragment

The non-destructive analysis of the cauldron fragment was performed with a handheld, portable X-ray fluorescence spectrometer (XRF) on a mechanically cleaned surface $(0.5 \times 0.5 \mathrm{~cm}) .{ }^{1}$ The other parts of the metal object were not cleaned, i.e. the patina and corrosion products were not removed with a view to possible future investigations. The original metal surface has a reddish colour and is strongly damaged with pitting. The reason for these phenomena is not known (whether they originate from the casting procedure, usage, corrosion or their combination).

Besides the cleaned part of the interior side, we also performed XRF measurements on the corroded and the green patinated surface of the interior side (lead enrichment) and the damaged part of the rib of the outer side of the fragment as well.

The technical parameters of the XFR analyser are as follows: Thermo Scientific Niton XL3t GOLDD+ portable handheld XRF with $50 \mathrm{kV} \mathrm{X-ray} \mathrm{tube} \mathrm{(Ag} \mathrm{anode)} \mathrm{and} \mathrm{large} \mathrm{drift} \mathrm{detector} \mathrm{with} \mathrm{a} \mathrm{resolution} \mathrm{of} 180 \mathrm{eV}$. For the quantitative analyses, the FP method and Compton normalisation was used with pre-set calibration packages according to the matrices. All measurements of the metal surface were performed with the "General Metals" calibration, while the patina and corrosion products were analysed using the "Mining" calibration as well.

The results of the XRF measurements are as follows:

\begin{tabular}{|l|c|c|c|c|c|c|c|c|l|l|l|l|l|}
\hline \multicolumn{1}{|c|}{$\% \mathbf{w} / \mathbf{w}$} & $\begin{array}{c}\text { Beam size } \\
(\mathbf{m m})\end{array}$ & $\mathbf{C u}$ & $\mathbf{P b}$ & $\mathbf{S n}$ & $\mathbf{S b}$ & $\mathbf{Z n}$ & $\mathbf{F e}$ & $\mathbf{N b}$ & $\mathbf{Z r}$ & $\mathbf{B i}$ & $\mathbf{M n}$ & $\mathbf{C r}$ & $\mathbf{V}$ \\
\hline 2016.4.1 1 clean (grated) & 3 & 96.26 & 2.97 & 0.28 & 0.09 & $<$ d.1. & 0.11 & $<$ d.1. & $<$ d.1. & $<$ d.1. & $<$ d.1. & $<$ d.1. & 0.06 \\
\hline 2016.4.1 2 corroded & 8 & 80.46 & 14.91 & 0.51 & 0.04 & 0.23 & 3.00 & 0.01 & 0.03 & 0.09 & 0.09 & $<$ d.1. & 0.21 \\
\hline 2016.4.1 4 rib, damaged & 3 & 92.53 & 6.67 & 0.31 & 0.09 & $<$ d.1. & 0.11 & $<$ d.1. & $<$ d.1. & $<$ d.1. & $<$ d.1. & $<$ d.1. & 0.09 \\
\hline 2016 5. thick corrosion & 8 & 78.08 & 18.93 & 0.25 & 0.03 & 0.10 & 1.81 & 0.01 & 0.02 & 0.05 & 0.05 & $<$ d.1. & 0.32 \\
\hline
\end{tabular}

d. 1.: detection limit

The composition of the cleaned metal surface was $96.26 \% \mathrm{~Pb}$ and $2.97 \% \mathrm{Cu}$. Intensive lead enrichment was measured for the corrosion product on the surface due to the selective corrosion processes occurring in copperlead systems. For a better and more precise determination of this metal fragment, we needed to study the texture of the metal, which may indicate the origin of the excess lead.

\footnotetext{
${ }^{1}$ The cleaning was done by conservator Júlia Józsa of the Budapest History Museum. We would here like to thank her for this work.
} 


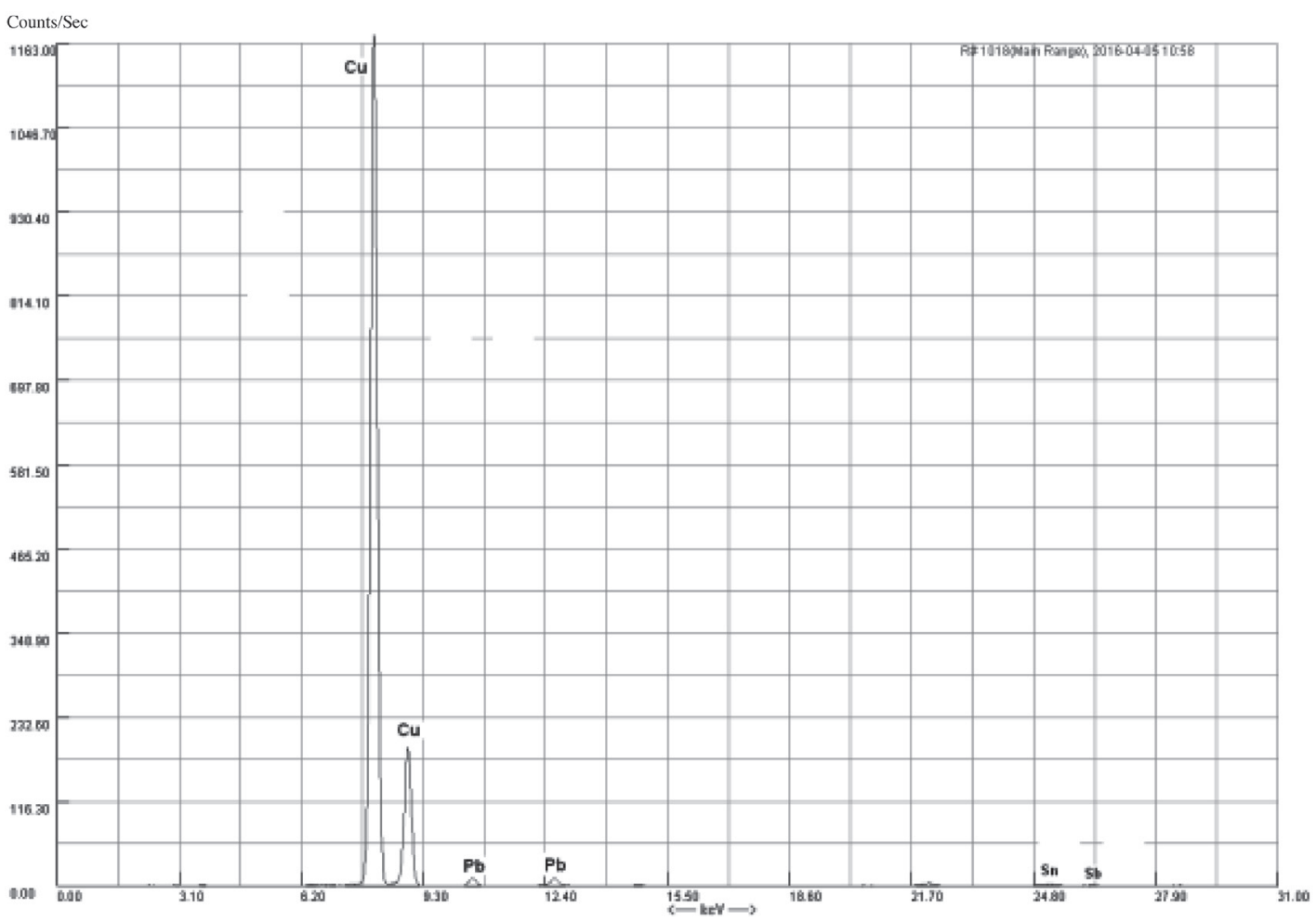

Fig. 1. XRF spectrum of the cleaned metal surface

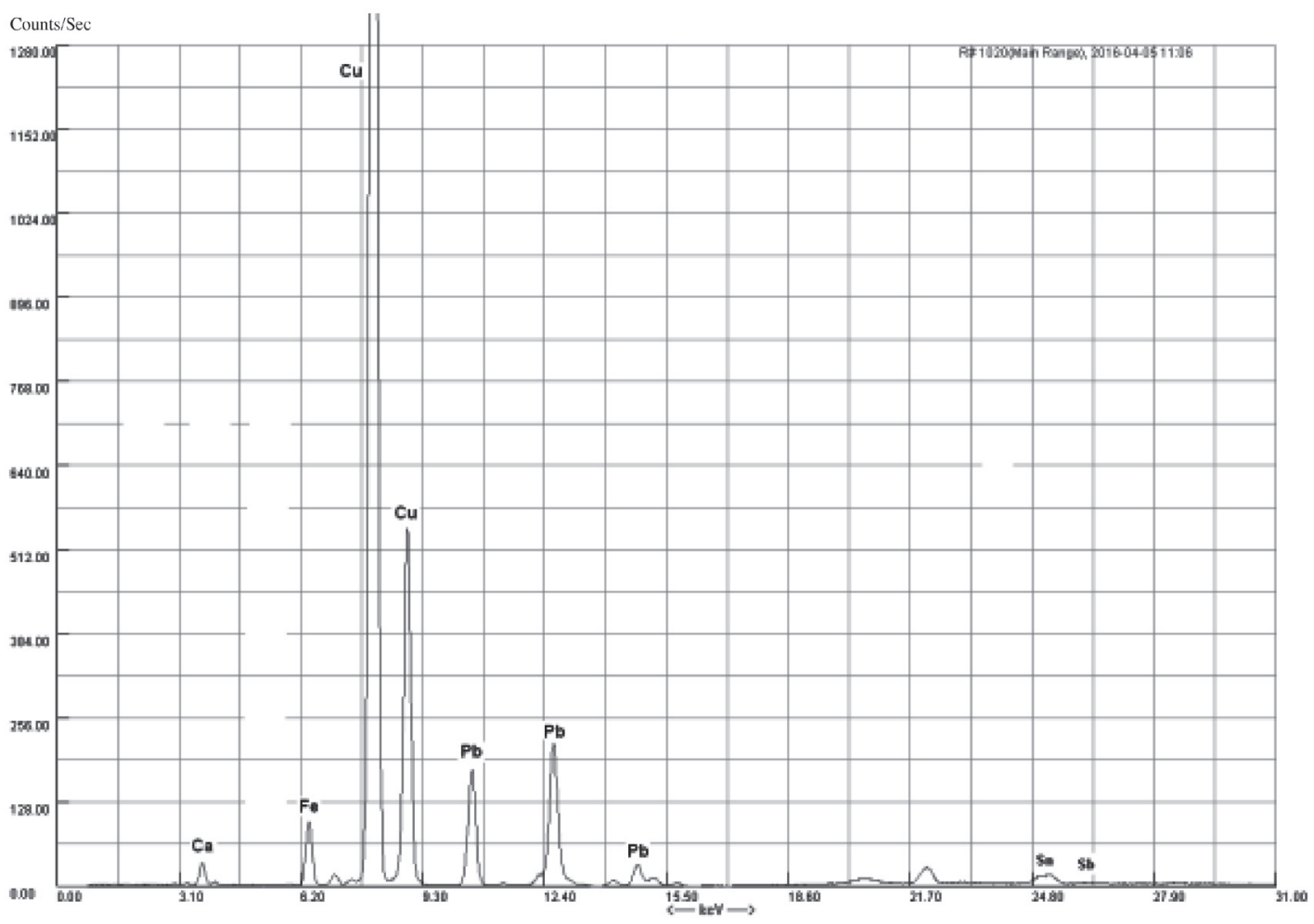

Fig. 2. XRF spectrum of the corroded metal surface 
The SEM EDX analysis of the cauldron fragment

Two samples were taken from the surface of the cauldron fragment for the SEM measurements: ${ }^{2}$ one from the upper left corner of the fragment (from the rib), the other from the lower left corner.

The images were made with a Zeiss Axio Imager M1m microscope at the Faculty of Materials Science and Engineering of the University of Miskolc (Hungary), the SEM images with an S4300-CFE scanning electron microscope at the Department of Solid State Physics of the University of Debrecen (Hungary).
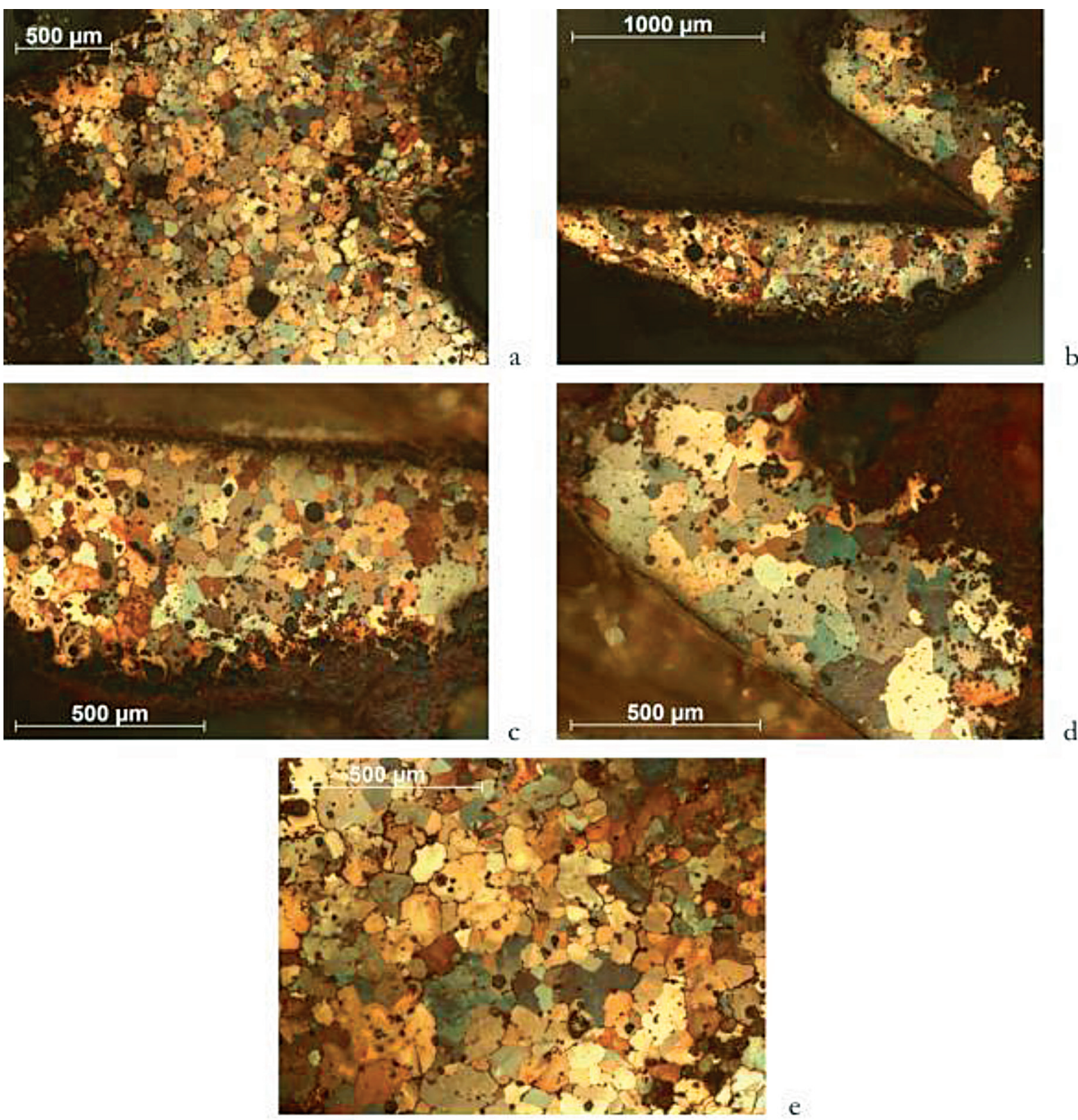

Fig. 3

${ }^{2}$ The sampling was performed by conservator Ádám Vecsey of the Budapest History Museum, whom we would here like to thank for his help. 
The SEM measurements only detected the presence of copper, lead and oxygen in the material of the fragment, indicating that the cauldron could have been cast from pure copper with $1 \mathrm{w} / \mathrm{w} \%$ of lead.

The cast structure can be seen clearly in Fig. 3.a-e, especially in Fig. $d$, which also shows the dendritic structure. The cast structure is also proven by the absence of twins, a very characteristic feature of annealed copper. The copper raw material itself of the fragment is very pure, without any inclusions with low melting points, except for lead. The measured amount of lead in the copper $(1 \mathrm{w} / \mathrm{w} \% \mathrm{~Pb})$ may indicate deliberately added lead (no impurity), but this calls for further investigations. It is difficult to correlate this copper composition with modern types, but it is sometimes designated as "heavy copper". It can hardly be described as lead-bronze due to the very low
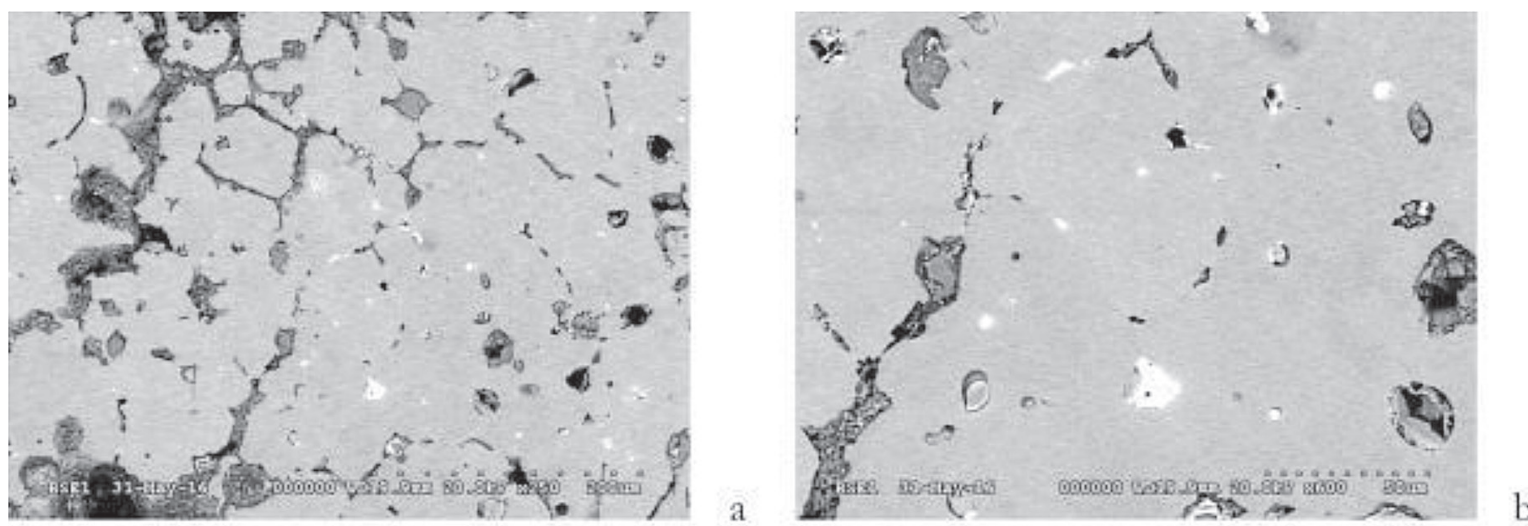

Fig. 4

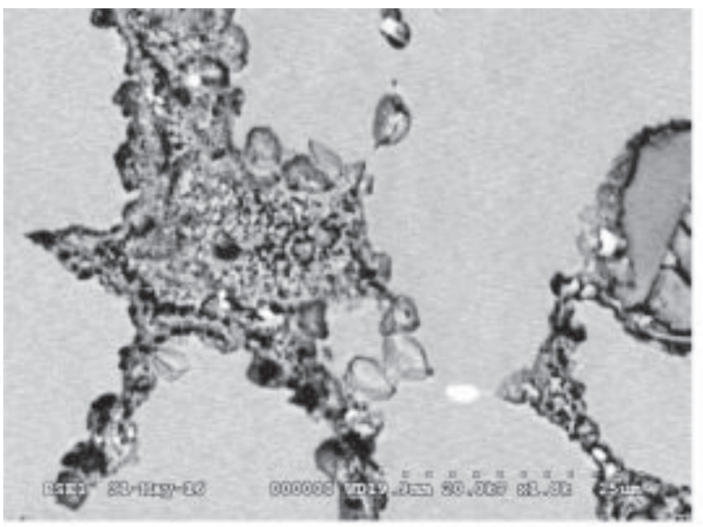

a
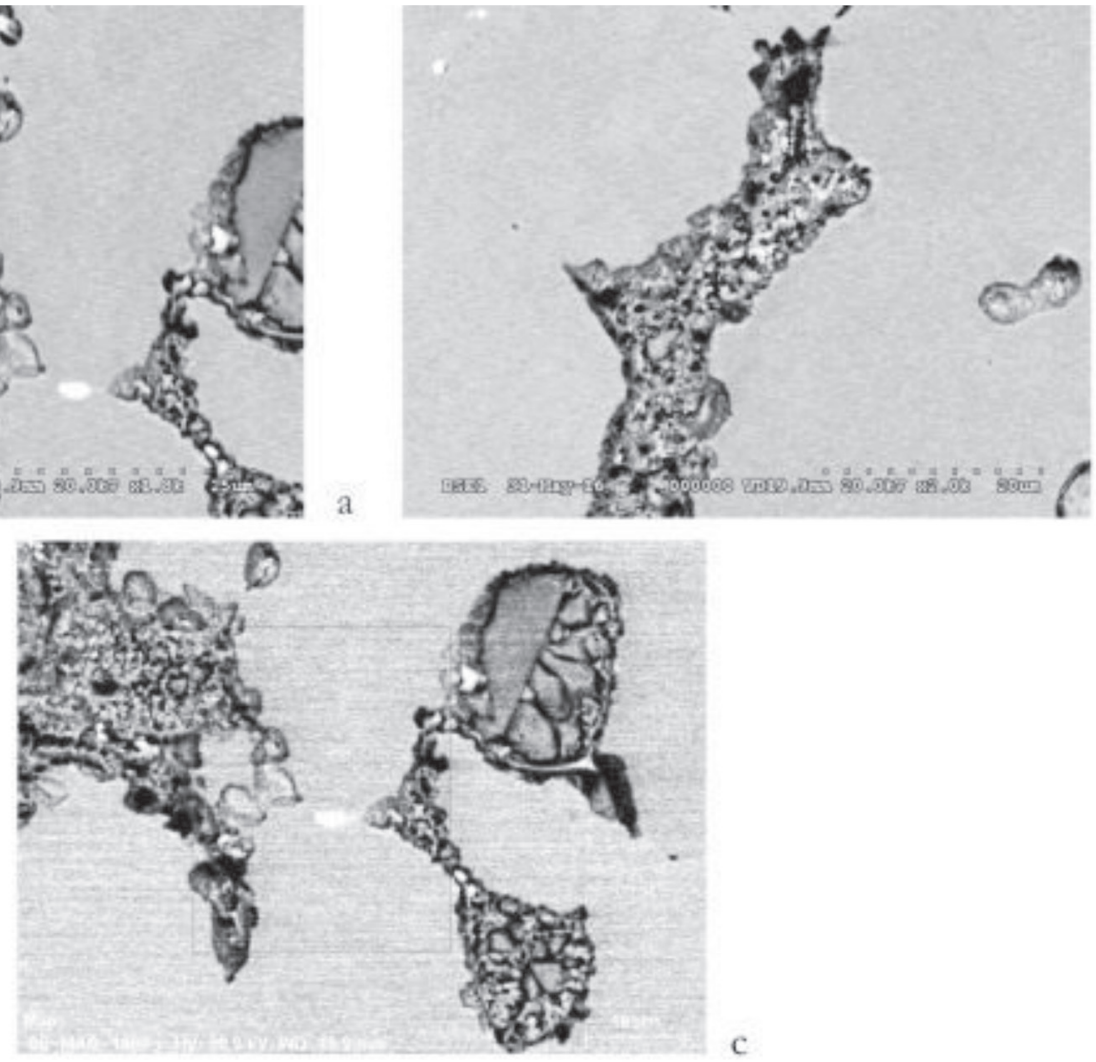

Fig. 5 


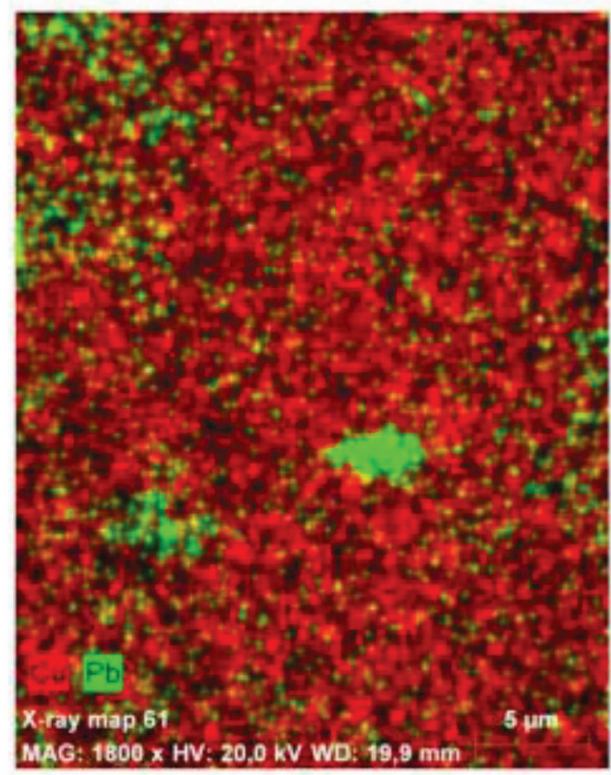

$\mathrm{X}$-ray map 61 Date:2016.05.31, 14:10:14

Image size:299 x $382 \mathrm{Mag}: 1800 \times \mathrm{HV}: 20,0 \mathrm{kV}$

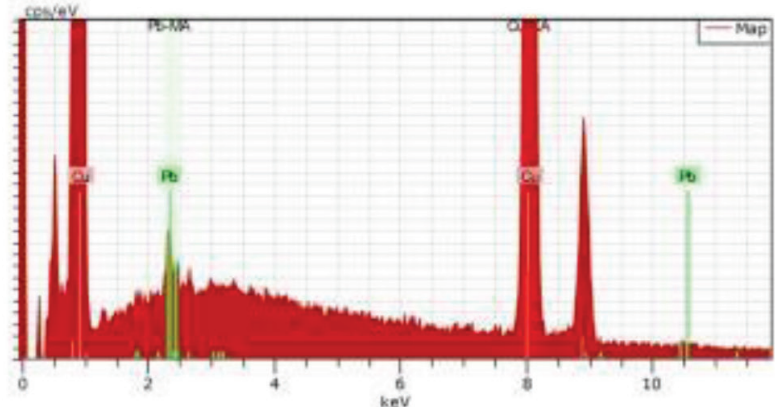

Map Date:2016.05.31. 14:10:14 HV:20,0kV Puls th.: $6,47 \mathrm{kcps}$

Fig. 6
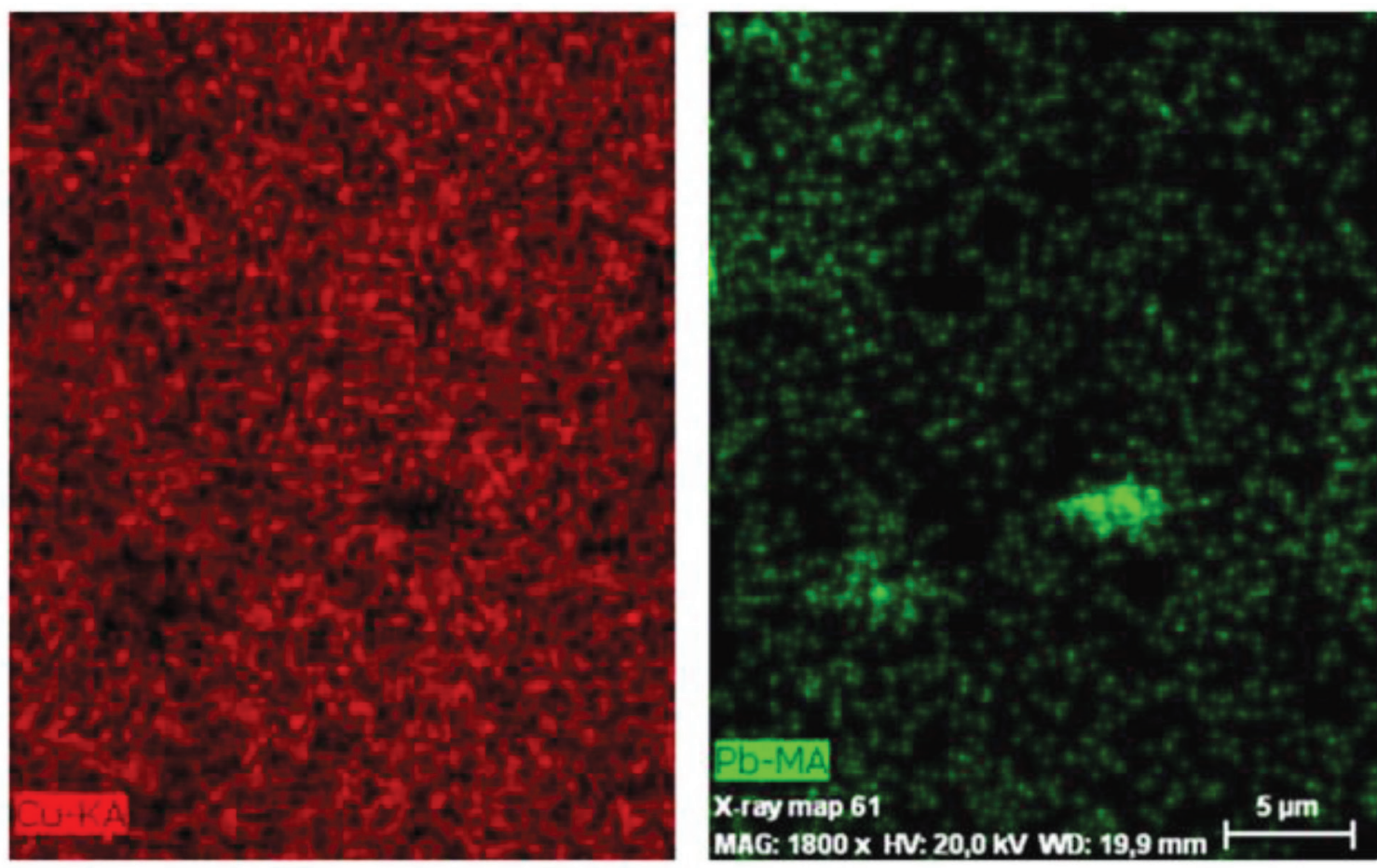

Cu-KA, Pb-MADate:2016.05.31. 14:12:51

Image size: $299 \times 382$

Mag: $1800 \mathrm{x}$

$\mathrm{HV}: 20,0 \mathrm{kV}$

Fig. 7 
concentration of lead in this fragment; similarly, a description as pure copper or red copper is inappropriate because this is a modern category of pureness.

The structure itself does not contain any other metallic phases, but there are numerous, often clear-cut black phases at the grain boundaries. Signs of serious corrosion are visible here and on the surface as well. The corrosion products at the grain boundaries indicate that the studied object was exposed to high temperature for a long time. In this case, the oxygen diffuses to the boundaries and forms copper oxides, which can catalyse the intergranular corrosion process. These features support the theory of the long exposure of the cauldron to fire since the carbon content of wood reacts with most of the oxygen during heating.

Fig. 4 shows the corrosion product of the intergranular corrosion (shown also in Fig. 5 at higher magnification). Lead appears in the form of white drops. Lead and copper do not blend with each other, with the former remaining as drop forms in the copper melt instead of solidifying during cooling. This is shown by the attached report (Figs 6-7).

The results of the XRF and SEM analyses are consistent with each other: the SEM measurements were performed on a very small area - local analysis - and the distribution of lead is very heterogeneous in a lead-copper system. These results cannot be compared with earlier data on Hungarian cauldrons obtained from spectrographic measurements because their values are relative intensities and the composition of the reference alloys is not known, and thus the conversion of these intensity values into concentration values is not possible. ${ }^{3}$

\section{REFERENCES}

АЧкИНАЗИ 1987

AjbABIN 2011

ALFÖLDI 1926

ALFÖLDI 1932

ALFÖLDI 1942

ALFÖLDI $1943^{2}$

Altheim-Haussig 1958

Altheim 1962

АмБРОз 1989

ANKE 1998

AsSMANn 2011

Attila 2007

BALANYI 1973

BÁLINT 2010

BÂRCĂ 2006
= И. Б. АЧкинАзи: Фрагмент гуннского котла из Неаполя Скифского [Fragment of a Hun cauldron from the Scythian Neapolis]. In: Материалы к этнической истории Крыма VII в. до н. э. Сборник научных трудов. Москва 1987, 207-210.

= A. I. AJBABIN: Archäologie und Geschichte der Krim in byzantinischer Zeit. Monographien des RGZM 98. Mainz 2011.

= A. ALFÖLDI: Der Untergang der Römerherrschaft in Pannonien. 2. Ungarische Bibliothek 12. Berlin 1926.

= A. ALFÖLDI: Leletek a hun korszakból és ethnikai szétválasztásuk - Funde aus der Hunnenzeit und ihre ethnische Sonderung. ArchHung 11. Budapest 1932.

= A. AlFöLDI: Aquincum a későrómai világban [Aquincum in the Late Roman world]. In: Budapest története. I: Budapest az ókorban. 2. Ed.: K. Szendy. Budapest 1942, 670-746.

= A. AlföLDI: Keletmagyarország a római korban [Eastern Hungary in Roman times]. A Magyar Történettudományi Intézet évkönyve 1943, 1-93. New edition: A. ALFöLDI: Magyarország népei és a Római Birodalom; Keletmagyarország a római korban [The Peoples of Hungary and the Roman Empire; Eastern Hungary in Roman Times]. Historia incognita: Az elfeledett magyar társadalomtudományok tára, 3. sorozat: Zsebkönyvek 13. Máriabesnyő 2014.

= F. Altheim-H.-W. Haussig: Die Hunnen in Osteuropa: ein Forschungsbericht. Baden-Baden 1958.

= F. Altheim: Geschichte der Hunnen. 4: Die europäischen Hunnen. Berlin 1962.

= А. К. Амьроз: Хронология древностей Северного Кавказа V-VII вв. [The chronology of the $5^{\text {th }}-7^{\text {th }}$-century antiquities from the North Caucasus]. Москва 1989.

= B. ANKE: Studien zur reiternomadischen Kultur des 4. bis 5. Jahrhunderts. BUFM 8. Weissbach 1998.

= J. Assmann: Cultural Memory and Early Civilization. Writing, Remembrance, and Political Imagination. Cambridge 2011.

= B. AnKe-H. EXTERnBrink (Hrsg.): Attila und die Hunnen. Begleitbuch zur Ausstellung Attila und die Hunnen, 2007-2008, Speyer. Stuttgart 2007.

= B. BALANYI: A Nagykőrös határában 1879-ben és 1894-ben folytatott ásatásokról (Ausgrabungen in Stadtgebiet von Nagykörös im Jahre 1879 und 1894). StComit 2 (1973) 13-35.

= Cs. BÁLINT: Der Schatz von Nagyszentmiklós. Archäologische Studien zur frühmittelalterlichen Metallgefäßkunst des Orients, Byzanz' und der Steppe. VAH 16/b. Budapest 2010.

= V. BÂRCĂ: Istorie şi civilizaţie. Sarmaţii în spaţiul est-carpatic (sec. I a. Chr. - începutul sec. II p. Chr) [History and Civilisation. The Sarmatians in the East Carpathians Region (1st century BC beginning of the 2nd century AD)]. Cluj-Napoca 2006.

\footnotetext{
${ }^{3}$ ZIMMER-JÁRÓ 1972. We are grateful to Márta Járó (re-
} tired metal conservator) for her kind assistance. 
BÂRCĂ 2012

BÂRCĂ-SYMONENKO 2009

BARKÓCZI 1954

BARKÓCZI 1957

BARKÓCZI-SALAMON 1973

БАТЧАЕВ 1984

BEMMANN-OESTERWIND 1995

БЕРНШТАM 1951

BIERBRAUER 2004

BIERBRAUER 2011

BIERBRAUER 2015

BIERBRAUER-NOTHDURFTER 2015

BÍRÓ-TOMKA, in print

BLINKHORN-BROWN 2015

БОКОвЕНКо 1978

BÓNA 1959

BÓNA 1963

BÓNA 1965

BÓNA 1968

BÓNA 1971

BÓNA 1971b

BÓNA 1979

BóNA 1984

BÓNA 1986

BÓNA 1987

BÓNA 1991
= V. BÂRCĂ: Some remarks on metal cups with zoomorphic handles in the Sarmatian environment. EphNap 22 (2012) 185-209.

= V. BÂRCĂ-O. SymonEnKo: Călăreţii stepelor. Sarmaţii în spaţiul Nord-Pontic (Horsemen of the Steppes. The Sarmatians in the North Pontic region). Cluj-Napoca 2009.

$=$ L. BARKóczi: Lager und Wohnsiedlung. In: L. Barkóczi et al.: Intercisa (Dunapentele-Sztálinváros). Geschichte der Stadt in der Römerzeit. I. ArchHung 33. Budapest 1954, 11-60.

= L. BARKóczI: Die Grundzüge der Geschichte von Intercisa. In: M. Alföldi-et al.: Intercisa. Geschichte der Stadt in der Römerzeit. II. ArchHung 36. Budapest 1957, 497-544.

= L. BARKóCZI-Á. SALAMON: Archäologische Angaben zur spätrömischen Geschichte des pannonischen Limes - Gräberfelder von Intercisa. MittArchInst 4 (1973) 73-95.

= В. М. БАТчАЕВ: Гуннский котел из селения Хабаз (А Hun cauldron from the Khabaz village). SA 1984/1, 256-258.

$=$ M. BemmanN-B. C. Oesterwind: Bemerkungen zum »Hunnenkessel « von Münstermaifeld. AKorr 25 (1995) 73-81.

= А. Н. БЕРНШТАМ: Очерк истории гуннов [A Brief History of the Huns]. Ленинград 1951.

= V. BIERBRAUER: Die Keszthely-Kultur und die romanische Kontinuität in Westungarn (5.-8. Jh.). Neue Überlegungen zu einem alten Problem. In: Von Sachsen bis Jerusalem, Menschen und Institutionen im Wandel der Zeit. Festschrift für Wolfgang Giese zum 65. Geburtstag. Hrsg.: H. Seibert, G. Thoma. München 2004, 51-72.

= V. BIERBRAUER: Zur archäologischen Nachweisbarkeit der „Alatheus-Safrax-Gruppe” in Pannonien. In: Römische Legionslager in den Rhein- und Donauprovinzen - Nuclei spätantik-frühmittelalterlichen Lebens? Hrsg.: M. Konrad, Ch. Witschel. ABAW NF 138. München 2011, 113-142.

$=$ V. Bierbrauer: Vom Schwarzmeergebiet bis nach Pannonien. Ethnische Interpretationsprobleme am Ende des 4. und in der ersten Hälfte des 5. Jahrhunderts. In: Romania gothica. II: The Frontier World: Romans, Barbarians and military culture. Proceedings of the International Conference at the Eötvös Loránd University, Budapest, 1-2 October 2010. Ed.: T. Vida. Budapest 2015, 365-475.

= V. BIERBRAUER-H. Nothdurfter: Die Ausgrabungen im spätantik-frühmittelalterlichen Bischofssitz Sabiona-Säben in Südtirol. I: Frühchristliche Kirche und Gräberfeld. MBV 58. München 2015.

= Sz. BíRó-P. TomKA: Über die mysteriöse „,schwarze Schicht” und das sog. ,hunnenzeitliche Gräberfeld" von Győr-Széchenyi Platz.

= P. BLINKHORN-D. H. Brown: Pottery and identity in late Saxon England. In: Tourner autour du pot... Les ateliers de potiers médiévaux du $\mathrm{V}^{\mathrm{e}}$ au $\mathrm{XII}^{\mathrm{e}}$ siècle dans l'espace européen. Actes du colloque international de Douai (5-8 octrobre 2010). Éd.: F. Thuillier, É. Louis. Caen 2015, 467-476.

= N. А. Боковенко: Типология бронзовых котлов сарматского времени в Восточной Европе (Typologie des chaudières en bronze d'époque sarmate en Europe orientale). SA 1977/4, 228-235.

= I. BónA: Magyarországi müvészet a honfoglalásig [The Art of Hungary before the Conquest Period]. Budapest 1959.

= I. BóNA [review]: Csallány Dezső: Archäologische Denkmäler der Gepiden im Mitteldonaubecken (454-568 u. Z.). Archaeologia Hungarica 38. Budapest, 1961. ArchÉrt 90 (1963) 137-140.

= I. BÓNA: Későrómai és népvándorlás korszak [Late Roman and Migration periods]. In: Orosháza története. Ed.: Gy. Nagy. Orosháza 1965, 114-135.

= I. BóNA: A népek országútján [On the highway of peoples]. In: A magyar régészet regénye. Ed. V. Szombathy. Budapest 1968, 100-134.

= I. BóNA: Ein Vierteljahrhundert Völkerwanderungszeit-forschung in Ungarn (1945-1969). ActaArchHung 23 (1971) 265-336.

= I. BÓNA: A népvándorlás kora Fejér megyében. Fejér megye története az őskortól a honfoglalásig 5 [The Migration Period in County Fejér. The history of county Fejér from the Prehistory to the Conquest period 5]. Székesfehérvár 1971.

= I. BÓNA: Die Archäologische Denkmäler der Hunnen und Hunnenzeit in Ungarn im Spiegel der internationalen Hunnenforschung. In: Nibelungenlied: Ausstellung zur Erinnerung an die Auffindung der Handschrift A des Nibelungenliedes im Jahre 1779 im Palast zu Hohenems. Hrsg.: E. Vonbank. Austellungskatalog des Vorareberger Laudesmuseums 86. Bregenz 1979, 297-342.

= I. BÓNA: A népvándorlás kor és a korai középkor története Magyarországon [The history of the Migration period and the Early Middle Ages in Hungary]. In: Magyarország története. 1/1-2: Előzmények és magyar történet 1242-ig. Ed.: A. Bartha. Budapest 1984, 265-373.

= I. BónA: Daciától Erdőelvéig. A népvándorlás kora Erdélyben (271-896) [From Dacia to Erdőelve. The Migration Period in Transylvania (271-896)]. In: L. Makkai-A. Mócsy: Erdély története a kezdetektől 1606-ig. Budapest 1986, 107-234.

= I. BóNA: Ungarns Völker im 5. und 6. Jahrhundert. Eine historisch-archäologische Zusammenschau. In: GHA 1987, 116-129.

= I. BÓNA: Das Hunnenreich. Stuttgart 1991 . 
BÓNA 2000

BORHY 2014

БотАЛов 2009

BRATHER 2007

BŘíZA-JANÁKOVÁ 2010

BUCHMAYR 2011

BURY 1923

Ciobanu-Constantinescu 2008

CIUPERCĂ-MĂGUREANU 2008

Coulston 2013

CSALlÁNy 1961

DAMM 1988

DAVIDESCU 1980

ДЕмидЕнко 2010

ДЕМИдЕнко 2014a

ДЕмиденко 2014b

Demougeot 1979

DÖVÉNYI 2010

EGER 2005

EGER 2015

ERDÉLYI-SUGÁR 1982

ÉRDY 1990

ÉRDY 1995

Europe without Borders 2007
= I. BÓNA: A pentelei Öreghegy és Intercisa erődjének története a késő római időktől a török kiűzéséig [The history of Öreghegy in Pentele and the fortress of Intercisa from the Late Roman times to the expulsion of the Turks]. In: Dunaújváros története. Ed.: F. Erdős, Zs. Pongrácz. Dunaújváros 2000, 69-78.

= L. BoRHY: Die Römer in Ungarn. Zaberns Bildbände zur Archäologie, Sonderbände der Antiken Welt. Darmstadt 2014.

= C. Г. БотАлов: Гунны и Тюрки (историко-археологическая реконструкция) [Huns and Turks. The Historical-Archaeological Reconstruction]. Челябинск 2009.

= S. BRATHER: Römer und Germanen. Ethnogenesen und Identitäten in der Spätantike. In: Barbaren im Wandel. Beiträge zur Kultur- und Identitätsumbildung in der Völkerwanderungszeit. Hrsg.: J. Tejral. Spisy Archeologického Ústavu AV ČR Brno 26. Brno 2007, 11-37.

= S. BŘíZA-M. JANÁKOvÁ: Lichnov (okr. Bruntál) [Lichnov (district Bruntál]. PV 51 (2010) 384.

= F. BuCHMAYR: Pariser Flair fürs NS-Büro. Justus Schmidts Einkaufstouren nach Paris im Auftrag von Gauleiter August Eigruber. In: Kunst sammeln - Kunst handeln. Internationales Symposium in Wien, Mittwoch, 23.-Freitag, 25. März 2011. Abstracts.

= J. B. BurY: History of the Later Roman Empire. From the Death of Theodosius I to the Death of Justinian. 1. London 1923.

= D. Ciobanu-E.-M. Constantinescu: Die Hunnen im Nordosten Munteniens. In: Hunnen zwischen Asien und Europa. Aktuelle Forschungen zur Archäologie und Kultur der Hunnen. Hrsg.: H. Externbrink. Beiträge zur Ur- und Frühgeschichte Mitteleuropas 50. Langenweissbach 2008, 131-141.

= B. CIUPERCĂ-A. MĂGUREANU: Huns and other peoples - archaeological evidence in present-day Romania. In: Hunnen zwischen Asien und Europa. Aktuelle Forschungen zur Archäologie und Kultur der Hunnen. Hrsg.: H. Externbrink. Beiträge zur Ur- und Frühgeschichte Mitteleuropas 50. Langenweissbach 2008, 119-130.

= J. C. N. Coulston: Late Roman military equipment culture. In: War and Warfare in Late Antiquity. Eds: A. C. Sarantis, N. Christie. Late antique archaeology 8. Leiden 2013, 463-492.

= D. CsallánY: Archäologische Denkmäler der Gepiden im Mitteldonaubecken. ArchHung 38. Budapest 1961.

= I. G. DAMM: Goldschmiedearbeiten der Völkerwanderungszeit aus dem nördlichen Schwarzmeergebiet. Katalog der Sammlung Diergardt 2. KJb 21 (1988) 65-210.

= M. DAVIDESCU: Săpăturile arheologice din castrul roman de la Hinova [Archaeological excavations of the Hinova Roman fort]. Drobeta 4 (1980) 77-86.

= C. В. ДЕмиденко: Раннесарматское погребение из могильника Верхний Еруслан - никаких «оксюморонов» (Early Sarmatian burial from the Upper Yeruslan cemetery - no "Oxymorons”). Нижневолжский археологический вестник 11 (2010) 365-373.

= С. В. ДЕмидЕнко: О позднесарматских бронзовых литых котлах (On the late Sarmatian bronze cast cauldrons). RA 2014/1, 26-31.

= C. В. ДЕмиденко: Котлы типа "Тахти-Сангин-Бармашино”: к проблеме взаимопроникновения традиций металлообработки в Центральной Азии (Cauldrons of the "Takhti-Sangin-Barmashino" type: to the problem of convergence of the metalwork in the Central Asia). RA 2014/4, 75-88.

$=$ É. Demougeot: La formation de l'Europe et les invasions barbares. II: De l'avènement de Dioclétien (284) à l'occupation germanique de l'Empire romain d'Occident (début du VI siècle). Paris 1979.

= Z. DövÉNYI (ed.): Magyarország kistájainak katasztere. Második, átdolgozott és bővített kiadás [The Gazetteer of the Microregions of Hungary. Second, revised and enlarged edition]. Budapest 2010.

$=\mathrm{CH}$. EGER: Zur Verbreitung und Herkunft der Polyederohrringe im südwestlichen Mittelmeerraum. MM 46 (2005) 437-471.

$=$ CH. EGER: Zur Deutung reich ausgestatteter Männergräber des mittleren 5. Jhs. im Mittelmeerraum. In: Romania gothica. II: The Frontier World: Romans, Barbarians and military culture. Proceedings of the International Conference at the Eötvös Loránd University, Budapest, 1-2 October 2010. Ed.: T. Vida. Budapest 2015, 237-283.

= I. ERdÉLYI-L. SugÁR: Ázsiai lovas nomádok: régészeti expedíciók Mongóliában [Asian Horsemen Nomads. Archaeological expeditions in Mongolia]. Budapest 1982.

= M. ÉRDY: Unique Xiong-nu cauldron from Urumqi. Inner Asia Report (Newsletter of the Harvard Students for Inner Asia) 7 (1990) 11-13.

= M. ÉRDY: Hun and Xiong-nu type cauldron finds throughout Eurasia. Eurasian Studies Yearbook 67 (1995) 5-94.

=W. Menghin (Hrsg.): Epocha Merovingov - Evropa bez granic: archeologija i istorija V-VIIII vv. $=$ Merowingerzeit - Europa ohne Grenzen $=$ The Merovingian Period - Europe without borders . Kataloghandbuch zur Ausstellung „Merowingerzeit - Europa ohne Grenzen, Archäologie und Geschichte des 5. bis 8. Jahrhunderts". Berlin 2007. 
FetTich 1940

FetTich 1953

FITZ 2003

GABLER-VADAY 1986

GABLER-VADAY 1992

ГАРЯИНОВ 1980

GHA 1987

GoDŁOWSKI 1995

GomolKa-Fuchs 2007

HAMPEL 1893

HAMPEL 1905

HARHOIU 1997

HARHOIU 2007

HARHOIU-DIACONESCU 1984

HARMATTA 1951

HARMATTA 1951b

HARMATTA 1953

HEATHER 1996

HEATHER 2009

HEINRICH-TAMÁSKA-PROHÁSZKA 2008

HEINRICH-TAMÁSKA-STRAUB 2015

HEKLER 1910

HEKLER 1911

VON HESBERG 1999

HODDER 1974

HONTI-NÉMETH 2007

HONTI et al. 2007
= N. Fetтich: A hunok régészeti emlékei [The archaeological heritage of the Huns]. In: Attila és hunjai. Ed.: Gy. Németh. Budapest 1940, 227-264.

= N. Feттісн: A szeged-nagyszéksósi hun fejedelmi sírlelet - La trouvaille de tombe princière hunnique à Szeged-Nagyszéksós. ArchHung 32. Budapest 1953.

$=\mathrm{J}$. FITZ: Historical outline of the Roman Period. In: Hungarian Archaeology at the Turn of the Millennium. Ed.: Zs. Visy, M. Nagy, Zs. Kiss. Budapest 2003, 205-208.

= D. Gabler-A. H. VadaY: Terra Sigillata im Barbaricum zwischen Pannonien und Dacien. FontArchHung. Budapest 1986.

= D. GABLER-A. H. VAdAY: Terra Sigillata im Barbaricum zwischen Pannonien und Dacien. 2. Teil. ActaArchHung 44 (1992) 83-160.

$=$ В. А. ГАряинов: Гуннское погребение в пещере Южного Приуралья (A Hun burial in a cave at the Southern Urals). SA 1980/4, 259-263.

= W. Menghin (Hrsg.): Germanen, Hunnen und Awaren: Schätze der Völkerwandererungszeit. Die Archäologie des 5. und 6. Jahrhunderts an der mittleren Donau und der östlich-merowingische Reihengräberkreis; Germanisches Nationalmuseum, Nürnberg, 12. Dezember 1987 bis 21. Februar 1988; Museum für Vor- und Frühgeschichte der Stadt Frankfurt am Main, 13. März bis 15. Mai 1988. Nürnberg 1987.

= K. GoDŁowsKI: Das „Fürstengrab” des 5. Jahrhunderts und der „Fürstensitz” in Jakuszowice in Südpolen. In: La noblesse romaine et les chefs barbares du $\mathrm{III}^{\mathrm{e}}$ au $\mathrm{VII}^{\mathrm{e}}$ siècle (Actes du colloque international du Musée des Antiquités nationales, Saint-Germain-en-Laye, 1992). Éd.: F. Vallet, M. Kazanski. Mémoires publiées par l'Association Française d'Archéologie Mérovingienne 9. Condé-sur-Noireau 1995, 155-179.

= G. GoMOLKA-Fuchs: Spätrömische Limeskastelle an der mittleren und unteren Donau im Licht des ostgermanischen und reiternomadischen Fundstoff. In: Attila 2007, 209-215.

= J. HAMPEL: Skythiai emlékek Magyarországban [Scythian heritage in Hungary]. ArchÉrt 13 (1893) 385-407.

= J. HAMPEL: Alterthümer des frühen Mittelalters in Ungarn. Braunschweig 1905.

= R. HARHOIU: Die frühe Völkerwanderungszeit in Rumänien. Archeologia Romanica 1. Bukarest 1997.

= R. HARHOIU: Hunnen und Germanen an der unteren Donau. In: Attila 2007, 82-95.

= R. HarhoiU-P. Diaconescu: Hunnischer Kessel aus Muntenien. Dacia 28 (1984) 99-115.

$=$ J. HARMATTA: The golden bow of the Huns. In: ActaArchHung 1 (1951) 107-148. = A hun aranyíj. MTAK(II) 3 (1951) 123-187.

= J. HARMATTA: Elöszó - Vorwort. In: N. Fettich: Régészeti tanulmányok a késői hun fémművesség történetéhez - Archäologische Studien zur Geschichte der späthunnischen Metallkunst. ArchHung 31. Budapest 1951, 3-8/99-105.

= J. Harmatta: Elöszó - Préface. In: FetTich 1953, 6-13/103-112.

= P. HEATHER: Afterword. In: E. A. Thompson: The Huns (Revised edition of: A history of Attila and the Huns, 1948). The peoples of Europe. Cambridge, Mass. 1996, 238-264.

= P. HEATHER: Empires and Barbarians. London 2009.

= O. HeinRICH-TAMÁSKa-P. ProhászKa: Pannonien zwischen Spätantike und Attilazeit am Beispiel von Tokod und Keszthely-Fenékpuszta. In: Hunnen zwischen Asien und Europa. Aktuelle Forschungen zur Archäologie und Kultur der Hunnen. Hrsg.: H. Externbrink. Beiträge zur Ur- und Frühgeschichte Mitteleuropas 50. Langenweissbach 2008, 143-156.

$=$ O. HeINRICH-TAMÁSKA-P. STRAUB: Zur Datierung und Deutung der Gräber und Gräberfelder des 5 . Jahrhunderts n. Chr. in Pannonia Prima und Valeria. In: Romania gothica. II: The Frontier World: Romans, Barbarians and military culture. Proceedings of the International Conference at the Eötvös Loránd University, Budapest, 1-2 October 2010. Ed.: T. Vida. Budapest 2015, 617-651.

= A. HEKLER: A N. Múzeum dunapentelei ásatásai 1908-ban és 1909-ben (Les fouilles du musée nat hongrois à Dunapentele en 1908 et 1909). ArchÉrt 30 (1910) 28-38.

= A. HEKLER: Római vassisakok Dunapenteléről [Casques romains en fer trouvés à Intercisa (Dunapentele) (C. de Fejér)]. ArchÉrt 31 (1911) 253-260.

$=$ H. vON HeSBERG (Hrsg.): Das Militär als Kulturträger in römischer Zeit. Schriften des Archäologischen Instituts der Universität zu Köln. Köln 1999.

= I. HODDER: Some marketing models for Romano-British coarse pottery. Britannia 5 (1974) 340-359.

= Sz. HonTI-P. G. NÉMETH: Hun áldozati üst Balatonlelle-Rádpusztáról (Hun period sacrificial cauldron from site Balatonlelle-Rádpuszta). SMK 17 (2006) [2007] 71-78.

= Sz. Honti-Sz. Fábián-Zs. Gallina-Á. D. Hajdú-P. HornoK-I. Koós-Zs. Mersdorf-I. MolnárP. G. Németh-P. Polgár-J. P. SzeōKe-G. Serlegi-Zs. Siklósi-C. Sipos-K. Somogyi: Régészeti kutatások az M7-es autópálya Somogy megyei szakaszán és a 67-es úton (2004-2005). Előzetes jelentés IV (Archaeological research on the Somogy county section of the M7 highway and on Route No. 67. (2004-2005). Preliminary report IV). SMK 17 (2006) [2007] 7-70. 
ISTVÁNOVITS-KULCSÁR 1997

ISTVÁNOVITS-KULCSÁR 2014

JERVIS 2015 KACZANOWSKI-RODZIŃSKA-NowAK 2008 = P. KACZANOwSKI-J. RoDZiŃSKA-NowaK: Die späteste Phase der Siedlung der Przeworsk-Kultur in Jakuszowice, Fdst. 2, Kleinpolen. In: The Turbulent Epoch. New materials from the Late Roman Period and the Migration Period. Eds: M. Niezabitowska-Wiśniewska, M. Juściński, P. Łuczkiewicz, S. Sadowski. Monumenta studia gothica 5. Lublin 2008, 179-188.

KARGER 1922

KARGER 1940

KAZANSKI 1993

КАЗАНСКИЙ 2014

KAZANSKI-MASTYKOVA 2000

\section{KAZANSKI-MASTYKOVA 2003}

KAZANSKI-MASTYKOVA 2007

Khatchatourova 2001

KISS 2008

КосH 1997

КосH 2007a

KoCH 2007b

Kocsis 2000

Kocsis 2008

KoCSIS-MrÁv 2010

КОЧКИНА-СТАШЕНКОВ 2014

KOMAP 2013

= E. IsTVÁNOVITS-V. KULCSÁR: Adatok az alföldi szarmaták vallásához és törzsi hovatartozásához (Some data on the religion and tribal attribution of the Sarmatians of the Great Hungarian Plain). JAMÉ 37-38 (1997) 157-188.

= E. IstvÁNOVITS-V. Kulcsár: New find of Hun Age saddle plates from North-East Hungary. In: Archäologische Beiträge - Gedenkschrift zum hundertsten Geburtstag von Kurt Horedt. Hrsg.: S. Cociş. Cluj-Napoca 2014, 269-278.

= B. JERVIS: The context of pottery production in late Saxon Chichester, England. In: Tourner autour du pot... Les ateliers de potiers médiévaux du V $V^{\mathrm{e}}$ au XII ${ }^{\mathrm{e}}$ siècle dans l'espace européen. Actes du

= V. KARGER: Die Vorgeschichtsforschung in Schlesien und ide Ausstellung vor- und frügeschichtlicher Altertümer im Schlesischen Landesmuseum. Anzieger des Schlesischen Landes-Museums in Troppau 1 (1922) 4-34.

= V. KARGER: Neues zu den Fund- und Erwerbungsumständen des Bronzekessels von Bennisch-Raase, Bezirk Troppau. Altschlesien. Mitteilungen des Schlesischen Altertumsvereins 9 (1940) 112-114.

= M. KAZANSKI: Les Barbares orientaux et la défense de la Gaule aux IV $-V^{\mathrm{e}}$ siècles. In: L'armée romaine et les Barbares du III ${ }^{\mathrm{e}}$ au VII ${ }^{\mathrm{e}}$ siècle. Éd.: M. Kazanski, F. Vallet. Mémoires publiées par l'Association Française d'Archéologie Mérovingienne 5. Rouen-Saint-Germain-en-Laye 1993, 175-186.

= М. М. КАЗАнский: Погребение эпохи переселения народов в Концештах: инвентарь, датировка, погребальный обряд, социальный статус и этнокультурная атрибуция (A burial of the Migration Period in Conceşti: Inventory, dating, funeral rites, social status and ethnocultural attribution). Stratum Plus 4 (2014) 299-336.

= M. KaZAnski-A. Mastykova: Les Alains sur le Dniepr à l'époque des Grandes Migrations: le témoignage de Marcien et les données archéologiques. In: Gentes, Reges und Rom. Auseinandersetzung - Anmerkung - Anpassung: Festschrift für Jaroslav Tejral zum 65. Geburtstag. Hrsg.: J. Bouzek, H. Friesinger, K. Pieta, B. Komoróczy. Spisy Archeologického Ústavu AV ČR Brno 16. Brno 2000, 209-219.

= M. KAZAnSKI-A. Mastykova: Les peuples du Caucase du Nord. Le début de l'histoire ( ${ }^{\text {er }}-$ VII ${ }^{\mathrm{e}} \mathrm{s}$. apr. J.-C.). Collection des Hesperides. Paris 2003.

= M. KAZANSKI-A. MastyKovA: Machtzentren und Handelswege in Westalanien im V.-VI. Jahrhundert. In: Barbaren im Wandel. Beiträge zur Kultur- und Identitätsumbildung in der Völkerwanderungszeit. Hrsg.: J. Tejral. Spisy Archeologického Ústavu AV ČR Brno 26. Brno 2007, 173-197.

= E. A. Khatchatourova: Gorgippia, cité antique sarmatisée. In: L'or des Amazones: peuples nomades entre Asie et Europe, VIe siècle av. J.-C. - IVe siècle apr. J.-C.; Musée Cernuschi, Musée des Arts de 1'Asie de la Ville de Paris, 16 mars - 15 juillet 2001. Éd.: V. Schiltz. Paris 2001, 262-266.

= M. KIss: Gót vezéregyéniségek a késő római birodalomban. Getica-kutatások. (Gotische Leitpersönlichkeiten im späten Römerreich. Getica-Forschungen.) Pécs 2008.

= A. Kосн: Ein hunnische Kessel aus Westchina. AKorr 27 (1997) 631-643.

= A. KосH: Hunnisches in Xinjiang? Überlegungen zum europäisch-asiatisches Kulturaustausch an der Wende zum Mittelalter. In: Attila 2007, 135-144.

= A. KocH: Hunnische Kessel. In: Attila 2007, 287-289.

= L. Kocsis: Helme von Typ „Intercisa” in Pannonien. In: Von Augustus bis Attila. Leben am ungarischen Donaulimes (erschienen anlässlich der gleichnamigen Sonderausstellung des Ungarischen Nationalmuseums Budapest, vom Dezember 2000 - Januar 2002). Red.: S. Biegert, C. Nickel. Schriften des Limesmuseums Aalen 53. Stuttgart 2000, 37-40.

= L. Kocsis: New Data on the question of morphology and dating of the Intercisa III type helmets. JRMES 16 (2008) 249-272.

= L. Kocsis-Zs. Mráv: Egy késő római sisak arcvédő lemezének töredéke Dunafalváról (Bács-Kiskun megye). Új adatok az Intercisa típusú sisakok morfológiai és keltezési kérdéseihez - Fragment of the cheek piece of a late Roman helmet from Dunafalva (County Bács-Kiskun, Hungary). Remarks on the morphology and dating of Intercisa type helmets. FolArch 54 (2008-2010) [2010] 185-203.

= А. Ф. КочкинА-Д. А. СтАшЕНКов: По Самаре с археологом: Путеводитель по археологическим памятникам [In Samara with an Archaeologist: Guide to the archaeological monuments]. Самара 2014.

= А. В. КомАР: Комплекс из Макартета и ритуальные памятники гуннского времени (Makartet complex and ritual monuments of the Hun epoch). In: Гуннский форум. Проблемы происхождения и идентификации культуры евразийских гуннов. Гл. ред.: С. Г. Боталов. Челябинск 2013, 88-109. 
KONRAD-WITSCHEL 2011

Косяненко-Флёров 1978

KovÁCs 2004

KOVRIG 1972

KOVRIG 1985

KRAPIVINA 2010

KRAUSE 1904

КРЫЖИЦКИЙ-РУСЯЕВА-ЧЕРНЕНКО et al. 1986

Кульчар-Иштванович 2013

КурчАтов-ТЕЛЬНОв 2010

LÁSZLÓ 1942

LÁSZLÓ 1946

LÁSZLÓ 1951

LÁSZLÓ 1974

ŁOPUSIEWICZ-ŻMUDZIŃSKI 1991

LosKotovÁ 2011

ЛЕВЧЕНКО-СУПРУНЕНКо 1994

ЛИМБЕРИС-МАРЧЕНКО 2011

LUTTWAK 2009

MAMAEB 2014

MaenChen-HeLfen 1973

MÁRTON 1912

MENGHIN 2007

MÉSZÁROS 1970

MIKS 2014

MitREA 1961

Mócsy 1962

MócSY 1971
= M. KONRAD-CH. WiTSCHEL: Spätantike Legionslager in den Rhein- und Donauprovinzen des Imperium Romanum: Ein Beitrag zur Kontinuitätsdebatte. In: Römische Legionslager in den Rhein- und Donauprovinzen - Nuclei spätantik-frühmittelalterlichen Lebens? Hrsg. : M. Konrad, Ch. Witschel. ABAW NF 138. München 2011, 3-46.

= В. М. Косяненко-В. С.ФлЁРов: Бронзовые литые котлы Нижнего Подонья (к вопросу о типологии и хронологии) (Les chaudières coulées en bronze de la region du Don inférior. Typologie et chronologie). SA 1978/1, 192-205.

= P. KovÁcs: Hunkori sír Százhalombattán (A grave from the Hun Period at Százhalombatta). ComArchHung 2004, 123-150.

= I. L. KovRIG: Hunnischer Kessel aus der Umgebung von Várpalota. FolArch 33 (1972) 95-127.

= I. Kovrig: Das Diadem von Csorna. FolArch 36 (1985) 107-148.

$=$ V. V. KrapivinA: Amphorae of the $3-4^{\text {th }}$ centuries A.D. in Olbia Pontica. In: PATABS I. Production and Trade of Ampforae in the Black Sea. Eds: D. Kassab Tezgör, N. Inaishvili. Varia Anatolica 21. Paris 2010, 69-73.

= E. KRAUSE: Der Fund von Höckricht, Kreis Ohlau. SchlV 3 (1904) 46-50.

= С. Д. Крыжицкий-А. С. РусяевА-Е. В. Черненко и др.: Археология Украинской ССР. 2 : Скифо-сарматская и античная археология [The Archaeology of Ukrainian SSR. 2: ScythianSarmatian and Antique Archaeology]. Киев 1986.

= В. КульчАР-Э. ИштвАНОВич: Новая находка седельных обкладок гуннского времени из Северо-Восточной Венгрии (New find of saddle plates of Hun Age from North-Eastern Hungary). Stratum Plus 4 (2013) 1-6.

= C. И. КурчАтов-Н. П. Тельнов: Сарматский котел из Нижнего Поднестровья (A Sarmatian cauldron from the Lower Dniester). Stratum Plus 4 (2010) 137-144.

= Gy. LÁsZLó: Budapest a népvándorlás korában [Budapest in the Migration period]. In: Budapest története. I: Budapest az ókorban. Ed.: K. Szendy. Budapest 1942, 781-818.

= Gy. LÁsZLó: A népvándorlás lovasnépeinek ősvallása [The ancient religion of the horsemen peoples of the Migration period]. Kolozsvár 1946.

= Gy. LÁSZLÓ: The significance of the Hun golden bow. In: ActaArchHung 1 (1951) 91-103. = A hun aranyíj jelentősége. MTAK(II) 3 (1951) 105-122.

= GY. LÁSZLó: The Art of the Migration Period. Budapest 1974.

= R. ŁoPUSIEWICZ-M. ŻMUDZIŃSKI: Sprawozdanie z badań sondażowych przeprowadzonych w 1988 r. na wielokulturowej osadzie w Jędrzychowicach, woj. wrocławskie na stanowisku 9 (Reports on probing explorations carried out in 1988 at a multi-layer settlement at Jędrzychowice, Wrocław Province, Site 9). SilAnt 33-34 (1991) 74-83.

= Z. LoskotovÁ: Die Przeworsk-Kultur im südlichen Teil des Oberschlesiens am Ende der Römischen Kaiserzeit und am Anfang der Völkerwanderungszeit. PV 52 (2011) 111-137.

= Д. И. ЛЕВченко-А. Б. СУПРунЕнко: Находки гуннского времени в низовьях Ворсклы [Нun period finds in the lower Vorskla]. In: А. Б. Супруненко: Курганы Нижнего Поворсклья. Москва-Полтава 1994, 74-80.

= Н. Ю. ЛИМБЕРИС-И. И. МАРЧЕНКО: Погребения эпохи великого переселения народов и раннего средневековья из курганов степного Прикубанья (Burials of the Great Migration Epoch and the Early Middle Ages in barrows in the Kuban Steppe). Stratum Plus 5 (2011) 417-441.

= E. LutTwAK: The Grand Strategy of the Byzantine Empire. Cambridge, Mass-London 2009.

= Х. М. МАмаЕв: «Княжеское» п огребение У г. Магас (Ингушетия) [A princely burial near the town of Magas (Ingushetia)]. KSIA 234 (2014) 55-71.

= O. Maenchen-Helfen: The World of the Huns. Studies in Their History and Culture. Berkeley-Los Angeles 1973.

= L. MÁRTOn: Die wichtigsten Resultate vor- und frühgeschichtlicher Forschung in Ungarn (1911). PZ 4 (1912) 175-191.

=W. Menghin: The Merowingian Period - Europe without Borders. An introductory survey of the exhibition theme. In: Europe without Borders 2007, 26-54.

= GY. MÉsZÁROs: A regölyi korai népvándorláskori fejedelmi sír (Das Fürstengrab von Regöly aus der Völkerwanderungszeit). ArchÉrt 97 (1970) 66-92.

$=\mathrm{CH}$. MiKs: Ein spätrömischer Depotfund aus Koblenz am Rhein: Studien zu Kammhelmen der späten Kaiserzeit. Kataloge vor- und frühgeschichtlicher Altertümer 44. Mainz 2014.

= B. MitreA: Beiträge zum Studium der hunnischen Altertümer - Zwei neue Kesselgriffe aus dem südlichen Muntenien. Dacia 5 (1961) 549-558.

= A. MócsY: Pannonia. PWRE Suppl 9. Stuttgart 1962.

= A. Mócsy [review]: L. Várady: Das letzte Jahrhundert Pannoniens (376-476). Akadémiai Kiadó Budapest und A. M. Hakkert Verlag Amsterdam. 1969. 602 S. ActaArchHung 23 (1971) 347-360. 
Mócsy 1974

MócSY-FITZ 1990

MÜLLER 2003

MÜLLER-Novotny 2014

MRT 2

NAGY 1956

NAGY 1973

NeStor-Nicolaescu-PlopŞOR 1937

Новичихин 2014

НУДЕЛЬМАН 1967

PÁRDUCZ 1959

PÁRDUCZ 1974

PAulovics 1927

Petropoulos 1998

POHL 2007

PoPA 2007

PósTA 1896

ProhÁSZKA 2008

PROKHOROVA 2001

PULSZKY 1891

QuAst 2006

RAJTÁR-ZÁBOJNÍK 2010

RASCHKE 1940
= A. Mócsy: Pannonia and Upper Moesia: a history of the Middle Danube. Provinces of the Roman Empire. London-Boston 1974.

= A. Mócsy-J. Fitz: Eseménytörténet [Event history]. In: Pannonia régészeti kézikönyve. Eds:

A. Mócsy, J. Fitz. Budapest 1990, 31-51.

$=$ R. MÜLlER: Burials and society. In: Hungarian Archaeology at the Turn of the Millennium. Ed.:

Zs. Visy, M. Nagy, Zs. Kiss. Budapest 2003, 286-287.

= S. Müller-E. Novotny: Verbogen und Verborgen. Hunnenzeitliche Waffen im Depotfund von Katzelsdorf. In: Schatz Reich Asparn. Ur- und Frühgeschichte und Mittelalterarchäologie in Niederösterreich. Katalog der Dauerausstellung im MAMUZ Schloss Asparn/Zaya. Hrsg.: E. Lauermann. Asparn/Zaya 2014, 236-239.

= I. ÉRI-M. KELEMEN-P. NÉMETH-I. TORMA: Veszprém megye régészeti topográfiája. 2: A veszprémi járás. Magyarország régészeti topográfiája [Archaeological sites of Hungary] 2. Budapest 1969.

$=$ T. NAGY: Les campagnes d'Attila aux Balkans et la valeur du témoignage de Jordanès concernant les germains. ActaAntHung 4 (1956) 251-260.

$=$ T. NAGY: Budapest története az őskortól a honfoglalásig [The history of Budapest from the prehistory to the Conquest period]. In: Budapest története az őskortól az Árpád-kor végéig. Budapest története. I. Ed.: L. Gerevich. Budapest 1975, 39-216.

$=$ J. NeSTOR-C. S. NiCOLAESCU-PlopşOR: Hunnische Kessel aus der Kleinen Walachei. Germania 21 (1937) 178-182.

= А. М. Новичихин: Находка фрагментов котла «гуннского типа» у хут. Бужор близ Анапы (The find of fragments of the boiler "Hun type" near farmstead Bujor in the vicinity of Anapa). In: IV «Анфимовские чтения» по археологии Западного Кавказа. Западный Кавказ в контексте международных отношений в древности и средневековье. Материалы международной археологической конференции (г. Краснодар, 28-30 мая 2014 г.). Ред.: Т. А. Павленко, Р. Б. Схатум, В. В. Улитин. Краснодар 2014, 168-170.

$=$ Г. А. НудЕЛЬмАН: Гуннский котел из Молдавии (Un chaudron des Huns trouvé en Moldavie). SA 1967/4, 306-308.

= M. PÁRDUCZ: Archäologische Beiträge zur Geschichte der Hunnenzeit in Ungarn. ActaArchHung 11 (1959) 309-398.

= M. PÁRDUCZ: Tscherniachow-Sîntana de Mures und frühgepidische Kulturen in Ungarn (Beitrag zur Abhandlung von I. Bóna über den Stand der völkerwanderungszeitlichen Forschung in Ungarn). ActaArchHung 26 (1974) 187-201.

= I. PAUlovics: A dunapentelei római telep (Intercisa). A maradványok története, a kutatások irodalma, 1926. évi leletek (Die römische Ansiedlung von Dunapentele (Intercisa). Geschichte der Überreste, Bibliographie der Forschungen, Fundergebnisse von 1926). ArchHung 2. Budapest 1927.

$=\mathrm{J}$. Petropoulos: For Germany and themselves: The motivation behind the Nazi leaders plundering and collecting of art. II. Spoils of War - International Newsletter 5 (1998) 28-35.

=W. PoHL: Byzanz und die Hunnen. In: Attila 2007, 185-191.

$=$ R. PoPA: Frühhunnenzeitliche Besiedlung zwischen Ostkarpaten und Dnjestr. In: Attila 2007, 169-173.

= B. PóstA: A törteli magyar pogánykori leletek [The finds from Törtel from the Hungarian Conquest period]. ArchÉrt 16 (1896) 30-39.

= P. PROHÁSZKA: Imperium et barbaricum. Kapcsolatrendszerek a Kárpát-medencében a római birodalom és a barbár népek között a római császár- és koranépvándorlás-korban (Imperium et Barbaricum. Die Kontakte im Karpatenbecken zwischen Römischem Reich und den barbarischen Völker in der Römer- und Frühvölkerwanderungszeit. Budapest 2008). [Manuscript, http://doktori.btk.elte. hu/hist/prohaszka/]

$=$ T. A. Prokhorova: Une princesse sarmate a Kobiakovo (Fin du Ier siècle - debut du IIe siècle apr. J.-C.). In: L'or des Amazones: peuples nomades entre Asie et Europe, VIe siècle av. J.-C. - IVe siècle apr. J.-C.; Musée Cernuschi, Musée des Arts de l'Asie de la Ville de Paris, 16 mars - 15 juillet 2001. Éd.: V. Schiltz. Paris 2001, 219-228.

= F. PULSZKY: A magyar pogány sírleletek [The Hungarian Pagan Grave Finds]. ÉTtK 14/10. Budapest 1891.

= D. QuAST: Mediterrane Scheibenfibeln der Völkerwanderungszeit mit Closionnéverzierung - Eine typologische und chronologische Übersicht. AKorr 36 (2006) 259-278.

= J. RAJTÁR-J. ZÁBOJNíK: Fragmente von hunnischen Kesseln in Iža. In: Între stepă şi imperiu - Zwischen der Steppe und dem Reich - Between the Steppe and the Empire. Studii în onoarea lui Radu Harhoiu - Archäologische Studien für Radu Harhoiu zum 65. Geburtstag - Archeological Studies in honour of Radu Harhoiu at 65 ${ }^{\text {th }}$ Anniversary. Eds: A. Măgureanu, E. Gáll. Bucureşti 2010, 119-125. = G. RAschKE: Zum Bronzekessel von Raase-Bennisch. Altschlesien. Mitteilungen des Schlesischen Altertumsvereins 9 (1940) 114-119. 
РЕДІНА-РОСОХАЦЬКИЙ 1994

REINECKE 1896

RICE 1987

RÓMER 1870a

RÓMER $1870 b$

VON RUMMEL 2007

SALAMON 1976

SALIN 1967

SARTI 2015

ŠAŠEL 1979

SHCHUKIN-KAZANSKI-SHAROV 2006

SimONENKo 2008

Скрипкин 2000

SOPRONI 1985

SzÁsz 1943

TAKÁCS 1925

TAKÁCS 1927

TAKÁCS 1955

TAKÁCS 1959

TEICHNER 2011

TEJRAL 1988

TEJRAL 2000

TEJRAL 2010

TEJRAL 2011

TEJRAL 2015

B. Thomas 1971

THOMPSON 1948

TOMKA 1986

TOMKA 1987

TOMKA 1996

TOMKA 2001
= Є. Ф. РЕДІнА-О. А. РосохАЦьКИЙ: До вивчення гунських старожитностей Північно-Західного Причорномор'я [Contributions to the study of the Hun antiquities of the north-western coast of the Black Sea]. Археологія 1994/3, 152-155.

= P. REINECKE: Die skythischen Alterthümer im mittleren Europa. ZfE 28 (1896) 1-43.

= P. M. RICE: Pottery Analysis. A sourcebook. Chicago-London 1987.

= F. RómER: A czakói bronz-edény [Das Bronzegefäß von Czakó]. ArchÉrt 2 (1870) 290-292.

= F. RómER: A czakói bronzedény ügyéhez [To the case of the bronze vessel from Czakó]. ArchÉrt 3 (1870) 114-115.

= P. vON RUMMEL: Habitus barbarus. Kleidung und Repräsentation spätantiker Eliten im 4. und 5. Jahrhundert. Ergänzungsbände zum RGA 55. Berlin 2007.

= Á. SALAmON: Csontmühely Intercisában (Geweihmanufaktur in Intercisa). ArchÉrt 103 (1976) 207-215.

= E. SALIN: Quelques objets rares du Haut Moyen Âge. Comptes Rendus des Séances de l'Académie des Inscriptions et Belles-Lettres 111/3 (1967) 387-402.

= L. SARTI: Die spätantike Militärpräsenz und die Entstehung einer militarisierten „Grenzgesellschaft” in der nordwesteuropäischen limes-Region. In: Krieg, Militär und Migration in der Frühen Neuzeit. Hrsg.: M. Asche. Herrschaft und soziale Systeme in der frühen Neuzeit 9. Berlin 2008, 43-56.

= J. ŠAŠEL: Antiqui Barbari. Zur Besiedlungsgeschichte Ostnoricums und Pannoniens im 5. und 6. Jahrhundert nach der Schriftsquellen. In: Von der Spätantike bis zum frühen Mittelalter. Hrsg.: J. Werner, E. Ewig. Vorträge und Forschungen, Konstanzer Arbeitskreis für Mittelalterliche Geschichte 25. Sigmaringen 1979, 125-141.

= M. ShChukin-M. KaZAnski-O. Sharov: Des Goths aux Huns: Le Nord de la Mer Noire au BasEmpire et a l'époque des Grandes Migrations. BAR IntSer 1535. Oxford 2006.

= A. V. SimonenKo: Römische Importe in sarmatischen Denkmälern des nördlichen Schwarzmeergebietes. In: A. V. Simonenko-I. I. Marčenko-N. Ju. Limberis: Römische Importe in sarmatischen und maiotischen Gräbern zwischen Unterer Donau und Kuban. Archäologie in Eurasien 25. Mainz 2008, 1-94.

= A. С. Скрипкин: О китайских традициях в сарматской культуре [About the Chinese traditions in the Sarmatian culture]. In: Античная цивилизация и варварский мир. (Материалы 7-го археологического семинара. Краснодар, 8-11 июня 1999 г.). Ред.: Б. А. Раев. Краснодар 2000, 96-100.

= S. Soproni: Die letzten Jahrezehnte des pannonischen limes. MBV 38. München 1985.

= B. SzÁsz: A húnok története; Attila nagykirály [The History of the Huns; The Great King Attila]. Bartha Miklós-Társaság magyartörténeti szakosztályának kiadványai 5. Budapest 1943.

= Z. F. TAKÁTS: Chinesisch-hunnische Kunstformen. Hunnische Opferkessel. IBAI 3 (1925) 194-229.

= Z. F. TAKÁTS: Kínai-hunn kapcsolatok. Újabb adalékok (Chinesisch-hunnische Zusammenhänge. Neue Beiträge). ArchÉrt 41 (1927) 146-155.

$=$ Z. TAKÁTs: Catalaunischer Hunnenfund und seine ostasiatische Verbindungen. I-II. ActaOrHung 5 (1955) 143-173; 6 (1956) 65-90.

= Z. TAKÁTS: Neuentdeckte Denkmäler der Hunnen in Ungarn. ActaOrHung 9 (1959) 85-95.

= F. TeICHNER: Die Gräberfelder von Intercisa. II: Die Altfunde der Museumssammlungen in Berlin, Mainz und Wien. Bestandskataloge Museum für Vor- und Frühgeschichte 11. Berlin 2011.

= J. TEJRAL: Zur Chronologie der frühen Völkerwanderungszeit im mittleren Donauraum. ArchA 72 (1988) 223-304

= J. TEJRAL: Nové poznatky k nálezu „hunského” kotle z Razové [Neue Erkenntnisse zum Fund eines „hunnischen” Kessels von Razová]. Acta Historica et Museologica Universitatis Silesianae Opaviensis 5 (2000) 151-166.

= J. TEJRAL: Zur Frage der frühesten hunnischen Anwesenheit in donauländischen Provinzen am Beispiel des archäologischen Befundes. SlA 58 (2010) 81-122.

= J. TEJRAL: Einheimische und Fremde. Das norddanubische Gebiet zur Zeit der Völkerwanderung. Spisy Archeologického Ústavu AV ČR Brno 33. Brno 2011.

= J. TEJRAL: Zum Problem der Feinschmiedeproduktion im Mitteldonauraum während des 5. Jahrhunderts nach Chr. PA 106 (2015) 291-362.

= E. B. Thomas: Helme, Schilde, Dolche. Studien über römisch-pannonische Waffenfunde. Budapest 1971.

= E. A. Thompson: A History of Attila and the Huns. Oxford 1948 .

= P. ToмKA: Der hunnische Fürstenfund von Pannonhalma. ActaArchHung 38 (1986) 423-488.

= P. ToMKA: Die hunnische Fundkomplex von Pannonhalma. In: GHA 1987, 156-161.

= P. TomkA: Einige Probleme der Hunnenforschung in Pannonien. ZalaiMúz 6 (1996) 47-52.

= P. TomKA: Az árpási 5. századi sír (The grave of Árpás from the $5^{\text {th }}$ century). Arrabona 39 (2001) 161-188. 
TOMKA 2005

TOMKA 2007

TOMKA 2008

TóтH 1989

То́тн 2006

Tо́тн 2009

TUDOR 1941

TUdOR 1948

VADAY 2003

B. VÁGÓ 1971

VÁGÓ-BÓNA 1976

VÁCZY 1940

VÁRADY 1969

VÁRADY 1978

VIDA 2011

VISY 1977

VISY 1981

VISY 1988

VISY 2003

VISY 2010

VISY 2011

WÁGNER 1879

WERNER 1934

WERNER 1956

WOLFRAM 1979

WOSINSKY 1891

WOSINSKY 1896

YABLONSKY 2015

Ярыгин 2013
= P. TomKA: Die Rolle des mittleren Donauabschnittes in der Völkerwanderungszeit. In: Wasserwege. Lebensadern - Trennungslinien. Hrsg.: C. v. Carnap-Bornheim, H. Friesinger. Schriften des Archäologischen Landesmuseums. Ergänzungsreihe 3. Neumünster 2005, 125-148.

= P. TomKA: Über die Bestattungssitten der Hunnen. In: Attila 2007, 252-257.

= P. TomKA: Zwischen Hsiung-nu und Hunnen aus archäologischer Sicht. In: Hunnen zwischen Asien und Europa. Aktuelle Forschungen zur Archäologie und Kultur der Hunnen. Hrsg.: H. Externbrink. Beiträge zur Ur- und Frühgeschichte Mitteleuropas 50. Langenweissbach 2008, 91-100.

= E. Tóтн: Provincia Valeria Media. ActaArchHung 41 (1989) 197-226.

= E. Tóth: Valeria vége (The end of Valeria). Arrabona 44/1 (2006) 579-596.

= E. Tо́тн: Studia Valeriana. Az alsóhetényi és ságvári késő római erődök kutatásának eredményei [Studia Valeriana. Results of the research of the late Roman forts at Alsóhetény and Ságvár]. Helytörténeti sorozat 8. Dombóvár 2009.

= D. Tudor: Sucidava II. Seconde (1937) et troisième (1940) campagnes des fouilles et recherches archéologiques dans la fortresse de Celei, départmant de Romanaţi. Dacia 7-8 (1937-1940) [1941] 359-400.

= D. TudoR: Sucidava III. Quatrième (1942), cinquième (1943) et sixième (1945) campagnes des fouilles et recherches archéologiques dans la fortresse de Celei, départmant de Romanaţi. Dacia 12 (1945-1947) [1948] 145-208.

= A. VADAY: Cloisonné brooches in the Sarmatian Barbaricum in the Carpathian Basin. In: ActaArchHung 54 (2003) 315-421.

= E. B. VÁGÓ: Ausgrabungen in Intercisa (1957-1969). Alba Regia 11 (1971) 109-119.

= E. B. VÁGÓ-I. BóNA: Die Gräberfelder von Intercisa. 1: Der spätrömische Südostfriedhof. Budapest 1976.

= P. VÁCZY: A hunok Európában [The Huns in Europe]. In: Attila és hunjai. Ed.: Gy. Németh. Budapest 1940, 61-142.

= L. VÁRADY: Das letzte Jahrhundert Pannoniens 376-476. Budapest 1969.

= L. VÁRAdy: Die Auflösung des Altertums: Beiträge zu einer Umdeutung der alten Geschichte. Budapest 1978.

$=$ T. VIDA: Die Zeit zwischen dem 4. und dem 6. Jahrhundert im mittleren Donauraum aus archäologischer Sicht. In: Römische Legionslager in den Rhein- und Donauprovinzen - Nuclei spätantikfrühmittelalterlichen Lebens? Hrsg.: M. Konrad, Ch. Witschel. ABAW NF 138. München 2011, 615-650.

= Zs. VISY: Intercisa: Dunaújváros in the Roman Period. Budapest 1977.

= Zs. VISY: 5. századi sír Intercisában (Ein Grab aus dem 5. Jh. in Intercisa). ArchÉrt 108 (1981) 211-217.

= Zs. VISY: Der pannonische Limes in Ungarn. Budapest 1988.

= Zs. VISY: Intercisa castellum. In: The Roman Army in Pannonia. An archaeological guide of the Ripa Pannonica. Ed.: Zs. Visy. Pécs 2003, 116-118.

= Zs. VISY: Intercisa római erődje. Vezető a római limes Világörökségre jelölt magyarországi helyszíneire 2. [The Roman Fort of Intercisa. A guide to the Roman Limes World Heritage candidate sites in Hungary 2]. Pécs-Szekszárd 2010.

= Zs. VISY: Intercisa. In: Rómaiak a Dunánál. A ripa Pannonica Magyarországon mint világörökségi helyszín (Romans on the Danube. The Ripa Pannonica in Hungary as a World Heritage Site). Ed.: Zs. Visy. Pécs 2011, 52-58.

= J. WÁGNER: A nagykőrösi ásatások [The excavations at Nagykőrös]. ArchÉrt 13 (1879) 365-368.

= J. WeRnER [review]: Andreas Alföldi, Funde aus der Hunnenzeit und ihre ethnische Sonderung. Germania 18 (1934) 236-238.

= J. WERnER: Beiträge zur Archäologie des Attila-Reiches. ABAW NF 38. München 1956.

= H. WolfRAm: Geschichte der Goten: von den Anfängen bis zur Mitte des sechsten Jahrhunderts. Entwurf einer historischen Ethnographie. München 1979.

$=$ M. WosinSKY: A kaposvölgyi népvándorlás kori üst [The cauldron from the Migration period in the Kapos valley]. ArchÉrt 11 (1891) 427-431.

= M. WosinSKY: Tolnavármegye az őskortól a honfoglalásig [County Tolna from the Prehistory to the Conquest Period]. Budapest 1896.

= L. T. YABLONSKY: Unusual new findings at Filippovka-1 burial mound 1, Southern Urals. Archaeology, Ethnology and Anthropology of Eurasia 43/2 (2015) 97-108.

= С. А. Ярыгин: К вопросу о бронзовом котле из погребения в Боровом (On the issue of the bronze cauldron from the burial site in Borovoye). In: Гуннский форум. Проблемы происхождения и идентификации культуры евразийских гуннов. Гл. ред. С. Г. Боталов. Челябинск 2013, 441-446. 
Юдин 1997

ЗАЙЦЕВ 2003

ЗАСЕЦКАЯ 1994

ZASECKAJA-BOKOVENKO 1994

ZIMMER-JÁRÓ 1972

Ammianus

Claudius Marius Victor

Herodotus

Iordanes

Priscus
= А. И. Юдин: Сарматские погребения из курганов у с. Верхний Еруслан [Sarmatian burials from the mounds near Verhnii Yeruslan village]. Археологическое наследие Саратовского края. Охрана и исследования в 1996 году 1997, 170-182.

= Ю. П. ЗАЙЦЕВ: Неаполь Скифский (II в. до н. э. - III в. н. э.). Монография [The Scythian Neapolis (2nd century BC - 3rd century A. D). A monograph]. Симферополь 2003.

= И. П. ЗАСЕЦКАЯ: Культура кочевников южнорусских степей в гуннскую эпоху IV-VI вв. (Nomadic Culture of the South Russian Steppelands, the end of the fourth and the fifth centuries A. D). Санкт-Петербург 1994.

= I. P. Zaseckaja-N. A. Bokovenko: The origin of Hunnish cauldrons in East-Europe. In: The Archaeology of the Steppes. Methods and Strategies. Papers from the International Symposium held in Naples 9-12 November 1992. Ed.: B. Genito. Napoli 1994, 701-724.

= K. ZIMMER-M. JÁRÓ: Spektrographische Untersuchungen von hunnischen Kesseln. In: KovRIG $1972,122-125$.

\section{SOURCES}

= Ammianus Marcellinus: Römische Geschichte. mit einem Kommentar versehen v. S. Wolfgang. Teil I-IV. Schriften und Quellen der Alten Welt 21. Berlin 1971.

= Commodiani 'Carmina', ed. by Joseph Martin, and Claudii Marii Victorii 'Alethia', ed. by P. F. Hovingh. Corpus Christianorum, Series Latina. 128. Turnhout 1960.

= Herodotus: The Histories: The Complete Translation, Backgrounds, Commentaries. Translated by W. Blanco. Ed. by J. Tolbert Roberts. New York 2013.

= Iordanis Romana et Getica. Hrsg. von Th. Mommsen. MGHistorica. Scriptores. Auctores antiquissimi 5,1. Berlin 1882. Nachdruck 1982.

$=$ The fragmentary classicising historians of the Later Roman Empire. Eunapius, Olympiodorus, Priscus and Malchus. Ed. by R. C. Blockley. ARCA Classical and medieval texts. Papers and monographs 6. Liverpool 1981. 